Prepared in cooperation with the Capital Area Groundwater Conservation Commission; the Louisiana Department of Transportation and Development, Public Works and Water Resources Division; and the City of Baton Rouge and Parish of East Baton Rouge

\title{
Simulation of Groundwater Flow and Chloride Transport in the "1,500-Foot" Sand, "2,400-Foot" Sand, and "2,800-Foot" Sand of the Baton Rouge Area, Louisiana
}

Scientific Investigations Report 2019-5102 



\section{Simulation of Groundwater Flow and Chloride Transport in the "1,500-Foot" Sand, "2,400-Foot" Sand, and "2,800-Foot" Sand of the Baton Rouge Area, Louisiana}

By Charles E. Heywood, Maxwell Lindaman, and John K. Lovelace

Prepared in cooperation with the Capital Area Groundwater Conservation Commission; the Louisiana Department of Transportation and Development, Public Works and Water Resources Division; and the City of Baton Rouge and Parish of East Baton Rouge

Scientific Investigations Report 2019-5102 


\title{
U.S. Department of the Interior DAVID BERNHARDT, Secretary
}

\author{
U.S. Geological Survey \\ James F. Reilly II, Director
}

\section{U.S. Geological Survey, Reston, Virginia: 2019}

For more information on the USGS - the Federal source for science about the Earth, its natural and living resources, natural hazards, and the environment-visit https://www.usgs.gov or call 1-888-ASK-USGS.

For an overview of USGS information products, including maps, imagery, and publications, visit https://store.usgs.gov.

Any use of trade, firm, or product names is for descriptive purposes only and does not imply endorsement by the U.S. Government.

Although this information product, for the most part, is in the public domain, it also may contain copyrighted materials as noted in the text. Permission to reproduce copyrighted items must be secured from the copyright owner.

Suggested citation:

Heywood, C.E., Lindaman, M., and Lovelace, J.K., 2019, Simulation of groundwater flow and chloride transport in the "1,500-foot" sand, "2,400-foot" sand, and "2,800-foot" sand of the Baton Rouge area, Louisiana: U.S. Geological Survey Scientific Investigations Report 2019-5102, 49 p., https://doi.org/10.3133/sir20195102.

Associated data for this publication:

Heywood, C.E., 2019, SEAWAT model archive of chloride transport in the "1,500-foot", "2,400-foot", and "2,800-foot" sands of the Baton Rouge Area, Louisiana: U.S. Geological Survey data release, https://doi.org/10.5066/P9URJ380.

ISSN 2328-031X (print)

ISSN 2328-0328 (online)

ISBN 978-1-4113-4347-4 


\section{Acknowledgments}

The authors would like to thank the many people who have contributed substantially to a better understanding of the hydrogeology and saltwater encroachment in the Baton Rouge area in southeastern Louisiana. Members of the Capital Area Groundwater Conservation Commission provided guidance and assistance throughout this investigation. 



\section{Contents}

Acknowledgments ……...................................................................................................................

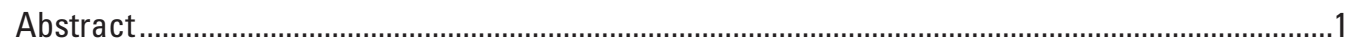

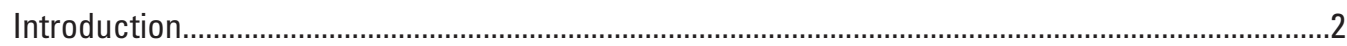

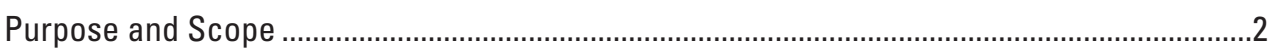

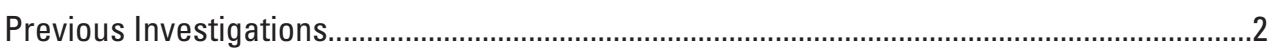

Study Area Description...............................................................................................

Horizontal Datum and Projection Systems .........................................................................

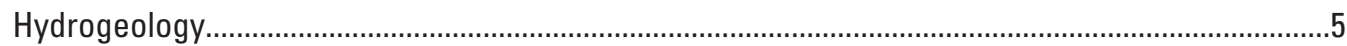

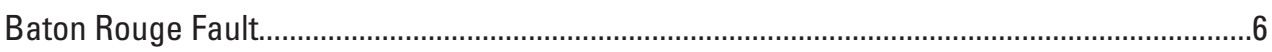

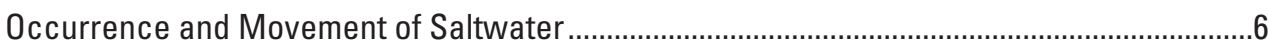

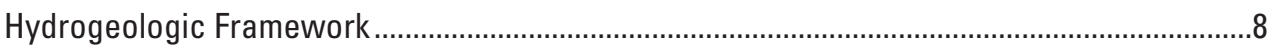

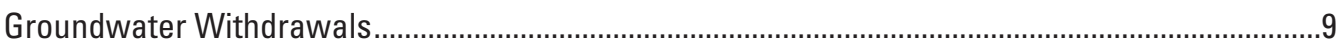

Simulation of Groundwater Flow and Chloride Transport.........................................................14

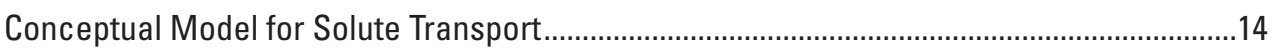

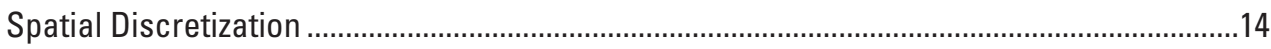

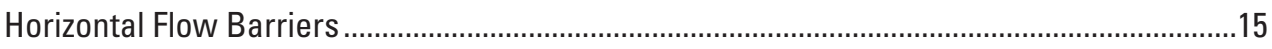

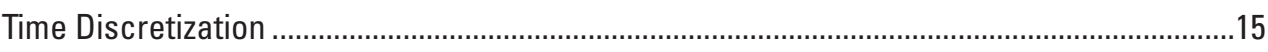

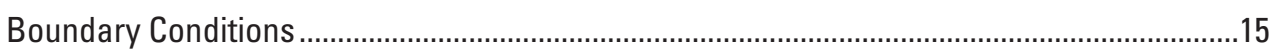

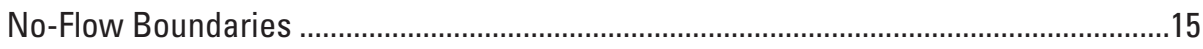

Specified-Head Boundaries........................................................................................

Head-Dependent Flux Boundaries................................................................................16

Specified-Concentration Boundaries and Initial Conditions ..........................................16

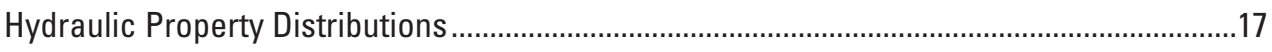

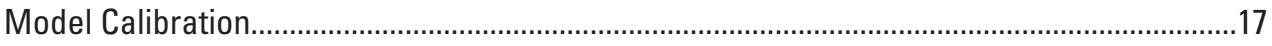

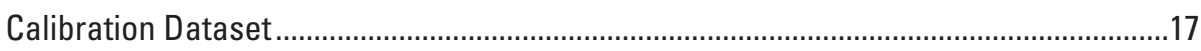

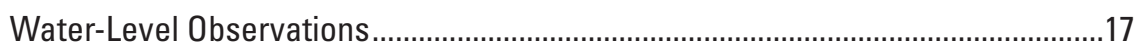

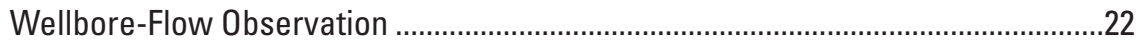

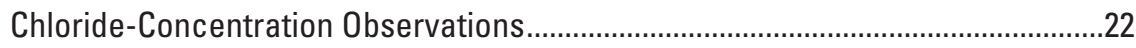

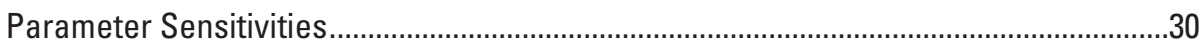

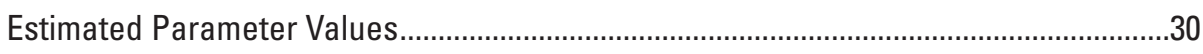

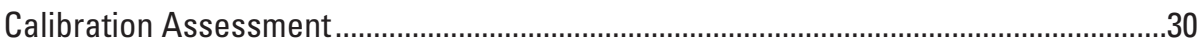

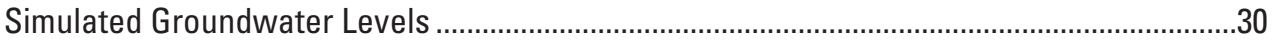

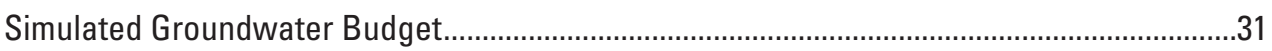

Simulated Concentrations .....................................................................................................

Limitations and Appropriate Use of the Model ........................................................................

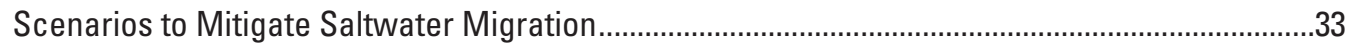

Scenario 1: Continued Groundwater Withdrawals at 2016 Rates .........................................33

Scenario 2: Decreased Groundwater Withdrawals From the "2,800-Foot" Sand ...................40

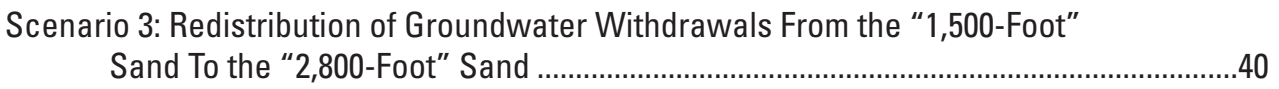

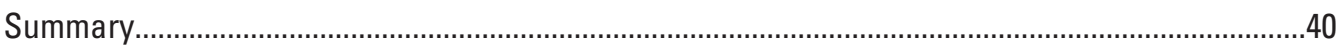

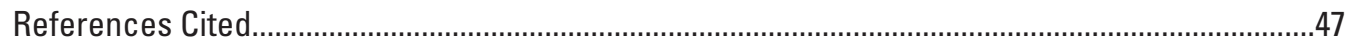




\section{Figures}

1. Map showing location of the study area, the Baton Rouge Fault, and geophysical control wells in southeastern Louisiana and southwestern Mississippi.....

2. Chart showing aquifers and aquifer systems in southern Mississippi and southeastern Louisiana and corresponding model layers

3. Map showing the thickness and altitude of the base of the "1,500-foot" sand of the Baton Rouge area in the groundwater model domain in southeastern Louisiana and southwestern Mississippi

4. North-to-south cross section along model column 43 showing aquifers, confining units, and finite-difference discretization

5. Graph showing estimated withdrawals from the Baton Rouge sands, 1940-2016.........10

6. Map showing average daily withdrawal rate during 2016 from wells screened in the "1,500-foot" sand of the Baton Rouge area and located at or near the city of Baton Rouge in southeastern Louisiana.

7. Map showing average daily withdrawal rate during 2016 from wells screened in the "2,400-foot" sand of the Baton Rouge area and located at or near the city of Baton Rouge in southeastern Louisiana.

8. Map showing average daily withdrawal rate during 2016 from wells screened in the "2,800-foot" sand of the Baton Rouge area and located at or near the city of Baton Rouge in southeastern Louisiana.

9. Hydrographs showing measured and simulated water levels within the "1,500-foot" sand of the Baton Rouge area in southeastern Louisiana

10. Map showing simulated 2016 water levels and chloride concentrations in the "1,500-foot" sand of the Baton Rouge area in the detailed model area in southeastern Louisiana

11. Hydrographs showing measured and simulated water levels within the "2,400-foot" sand of the Baton Rouge area in southeastern Louisiana

12. Map showing simulated 2016 water levels and chloride concentrations in the "2,400-foot" sand of the Baton Rouge area in the detailed model area in southeastern Louisiana

13. Hydrographs showing measured and simulated water levels within the "2,800-foot" sand of the Baton Rouge area in southeastern Louisiana

14. Map showing simulated 2016 water levels and chloride concentrations in the "2,800-foot" sand of the Baton Rouge area in the detailed model area in southeastern Louisiana

15. Graphs showing simulated and observed chloride concentrations at observation wells within the "1,500-foot" sand of the Baton Rouge area in southeastern Louisiana

16. Graphs showing simulated and observed chloride concentrations at observation wells within the "2,400-foot" sand of the Baton Rouge area in southeastern Louisiana

17. Graphs showing simulated and observed chloride concentrations at observation wells within the "2,800-foot" sand of the Baton Rouge area in southeastern Louisiana 
18. Graph showing water-level residuals in relation to simulated water-level altitude .......31

19. Map showing predicted 2047 water levels and chloride concentrations at the base of the "1,500-foot" sand of the Baton Rouge area in the detailed model area in southeastern Louisiana after continued pumping at 2016 rates

20. Map showing predicted 2112 water levels and chloride concentrations at the base of the "1,500-foot" sand of the Baton Rouge area in the detailed model area in southeastern Louisiana after continued pumping at 2016 rates.

21. Map showing predicted 2047 water levels and chloride concentrations in the "2,400-foot" sand of the Baton Rouge area in the detailed model area in southeastern Louisiana after continued pumping at 2016 rates.

22. Map showing predicted $\mathbf{2 1 1 2}$ water levels and chloride concentrations in the "2,400-foot" sand of the Baton Rouge area in the detailed model area in southeastern Louisiana after continued pumping at 2016 rates

23. Map showing predicted 2047 water levels and chloride concentrations in the "2,800-foot" sand of the Baton Rouge area in the detailed model area in southeastern Louisiana after continued pumping at 2016 rates.

24. Map showing predicted 2112 water levels and chloride concentrations in the "2,800-foot" sand of the Baton Rouge area in the detailed model area in southeastern Louisiana after continued pumping at 2016 rates.

25. Map showing predicted 2047 water levels and chloride concentrations in the "2,800-foot" sand of the Baton Rouge area in the detailed model area in southeastern Louisiana after cessation of pumping from selected wells screened in the "2,800-foot" sand beginning in 2017

26. Map showing predicted 2112 water levels and chloride concentrations in the "2,800-foot" sand of the Baton Rouge area in the detailed model area in southeastern Louisiana after cessation of pumping from selected wells screened in the "2,800-foot" sand beginning in 2017

27. Map showing predicted 2047 water levels and chloride concentrations in the "1,500-foot" sand of the Baton Rouge area in the detailed model area in southeastern Louisiana after redistribution of 2,000 gallons per minute of pumping from selected wells screened in the "1,500-foot" sand to the "2,800-foot" sand beginning in 2017

28. Map showing predicted 2112 water levels and chloride concentrations in the "1,500-foot" sand of the Baton Rouge area in the detailed model area in southeastern Louisiana after redistribution of 2,000 gallons per minute of pumping from selected wells screened in the "1,500-foot" sand to the "2,800-foot" sand beginning in 2017

29. Map showing predicted 2047 water levels and chloride concentrations in the "2,800-foot" sand of the Baton Rouge area in the detailed model area in southeastern Louisiana after redistribution of 2,000 gallons per minute of pumping from selected wells screened in the " 1,500 -foot" sand to the "2,800-foot" sand beginning in 2017

30. Map showing predicted 2112 water levels and chloride concentrations in the "2,800-foot" sand of the Baton Rouge area in the detailed model area in southeastern Louisiana after redistribution of 2,000 gallons per minute of pumping from selected wells screened in the "1,500-foot" sand to the "2,800-foot" sand beginning in 2017 


\section{Tables}

1. Summary of groundwater model time discretization

2. Parameter values and sensitivities for the calibrated groundwaterflow model.

3. Simulated steady-state and transient flow rates.

\section{Conversion Factors}

U.S. customary units to International System of Units

\begin{tabular}{|c|c|c|}
\hline Multiply & By & To obtain \\
\hline \multicolumn{3}{|c|}{ Length } \\
\hline inch (in) & 2.54 & centimeter $(\mathrm{cm})$ \\
\hline foot $(\mathrm{ft})$ & 0.3048 & meter $(\mathrm{m})$ \\
\hline mile (mi) & 1.609 & kilometer $(\mathrm{km})$ \\
\hline \multicolumn{3}{|c|}{ Area } \\
\hline square mile $\left(\mathrm{mi}^{2}\right)$ & 2.590 & square kilometer $\left(\mathrm{km}^{2}\right)$ \\
\hline acre & 4,047 & square meter $\left(\mathrm{m}^{2}\right)$ \\
\hline \multicolumn{3}{|c|}{ Flow rate } \\
\hline cubic foot per day $\left(\mathrm{ft}^{3} / \mathrm{d}\right)$ & 0.02832 & cubic meter per day $\left(\mathrm{m}^{3} / \mathrm{d}\right)$ \\
\hline gallon per minute (gal/min) & 0.06309 & liter per second $(\mathrm{L} / \mathrm{s})$ \\
\hline million gallons per day (Mgal/d) & 0.04381 & cubic meter per second $\left(\mathrm{m}^{3} / \mathrm{s}\right)$ \\
\hline \multicolumn{3}{|c|}{ Recharge } \\
\hline inch per year (in/yr) & 25.4 & millimeter per year $(\mathrm{mm} / \mathrm{yr})$ \\
\hline \multicolumn{3}{|c|}{ Hydraulic conductivity } \\
\hline foot per day $(\mathrm{ft} / \mathrm{d})$ & 0.3048 & meter per day $(\mathrm{m} / \mathrm{d})$ \\
\hline \multicolumn{3}{|c|}{ Velocity } \\
\hline foot per year $(\mathrm{ft} / \mathrm{yr})$ & 0.3048 & meter per year $(\mathrm{m} / \mathrm{yr})$ \\
\hline \multicolumn{3}{|c|}{ Molecular diffusion } \\
\hline foot squared per day $\left(\mathrm{ft}^{2} / \mathrm{d}\right)$ & 0.09290 & meter squared per day $\left(\mathrm{m}^{2} / \mathrm{d}\right)$ \\
\hline
\end{tabular}

Temperature in degrees Celsius $\left({ }^{\circ} \mathrm{C}\right)$ may be converted to degrees Fahrenheit $\left({ }^{\circ} \mathrm{F}\right)$ as follows:

$$
{ }^{\circ} \mathrm{F}=\left(1.8 \times{ }^{\circ} \mathrm{C}\right)+32 .
$$

Temperature in degrees Fahrenheit $\left({ }^{\circ} \mathrm{F}\right)$ may be converted to degrees Celsius $\left({ }^{\circ} \mathrm{C}\right)$ as follows:

$$
{ }^{\circ} \mathrm{C}=\left({ }^{\circ} \mathrm{F}-32\right) / 1.8 \text {. }
$$

Concentrations of chemical constituents in water are given in milligrams per liter (mg/L).

\section{Datum}

Vertical coordinate information is referenced to the National Geodetic Vertical Datum of 1929 (NGVD 29).

Horizontal coordinate information is referenced to the North American Datum of 1983 (NAD 83). Altitude, as used in this report, refers to distance above the vertical datum. 


\section{Abbreviations}

$\begin{array}{ll}\text { Commission } & \text { Capital Area Groundwater Conservation Commission } \\ \text { DNR } & \text { Louisiana Department of Natural Resources } \\ \text { DOTD } & \text { Louisiana Department of Transportation and Development } \\ \text { GIS } & \text { geographic information system } \\ \text { HFB } & \text { horizontal flow barrier } \\ \text { MNW2 } & \text { Multi-Node Well package } \\ \text { SMCL } & \text { Secondary Maximum Contaminant Level } \\ \text { USGS } & \text { U.S. Geological Survey }\end{array}$





\title{
Simulation of Groundwater Flow and Chloride Transport in the "1,500-Foot" Sand, "2,400-Foot" Sand, and "2,800-Foot" Sand in the Baton Rouge Area, Louisiana
}

\author{
By Charles E. Heywood, Maxwell Lindaman, and John K. Lovelace
}

\section{Abstract}

Groundwater withdrawals since the 1940s have lowered water levels, altered groundwater-flow directions, and caused saltwater to intrude within some freshwater-containing sands of the fluvial-deltaic Southern Hills regional aquifer system beneath Baton Rouge, Louisiana. New interpretations of stratigraphic correlations amongst geophysical well logs were utilized to revise a hydrogeologic framework that delineates the depth and thickness variations of aquifers and confining units in the Southern Hills regional aquifer system. A groundwater-flow and chloride-transport model incorporating the revised framework was constructed to assess the effects of groundwater withdrawals on the rate and pathways of saltwater migration in the "1,500-foot" sand, "2,400-foot" sand, and the "2,800-foot" sand. Groundwater withdrawals reported since 1940 were compiled to specify annual average withdrawal rates through 2016 for 722 wells. Regional groundwater flow throughout the Southern Hills regional aquifer system was first simulated with MODFLOW, and flow-model parameters were calibrated to 8,810 water levels observed through 2016 by using the parameter-estimation code PEST++. Saltwater transport was subsequently simulated for the "1,500-foot" sand, "2,400-foot" sand, and the "2,800-foot" sand by using the variable-density code, SEAWAT. Chloride-concentration measurements were used as a proxy for saltwater to formulate the concentration initial conditions and calibrate the transport-model parameters.

Three groundwater-management scenarios were simulated to evaluate the effects of different groundwater withdrawals on future groundwater levels and saltwater concentrations in the "1,500-foot" sand, "2,400-foot" sand, and "2,800-foot" sand. All three scenarios simulated the period from 2017 through 2112 (96 years), and the water levels and concentrations simulated for 2047 and 2112 were compared among the scenarios. The first scenario simulated a continuation of groundwater withdrawals at 2016 rates and represents the "status quo" of groundwater withdrawals. The second scenario simulated the effects of discontinuing 10,620 gallons per minute (gal/min) of withdrawals from the "2,800-foot" sand, and the third scenario simulated reallocating $2,000 \mathrm{gal} / \mathrm{min}$ of withdrawals from the "1,500-foot" sand to the "2,800-foot" sand. Continuation of the "status quo" withdrawals results in lower water levels by 2047 around groundwater-withdrawal locations in the "1,500-foot" sand, "2,400-foot" sand, and "2,800-foot" sand. By 2112, water levels recover to higher levels as flow in the aquifer approaches equilibrium. Saltwater within the "1,500-foot" sand would continue migrating toward publicsupply wells located 2.4 miles (mi) north of the Baton Rouge Fault, but a "scavenger well" that removes relatively concentrated water from the base of the "1,500-foot" sand attenuates chloride concentrations at the public-supply wells. Saltwater within the "2,400-foot" sand would continue to encroach on a well with large withdrawals and farther east within an area about 1 mi north of the Baton Rouge Fault. Saltwater within the "2,800-foot" sand would migrate northward toward withdrawal wells located about 3 mi north of the industrial district. Cessation of $10,620 \mathrm{gal} / \mathrm{min}$ of industrial withdrawals from the "2,800-foot" sand about $12 \mathrm{mi}$ northwest of the industrial district (scenario 2) would cause a substantial water-level recovery in the "2,800-foot" sand in the area of discontinued withdrawals. Groundwater levels 3 mi north of the industrial district would be 25-30 feet higher in 2047 than predicted for the "status quo" withdrawals. Saltwater encroachment toward wells north of the industrial district would be slowed because of the decreased hydraulic gradient. Reallocating 2,000 gal/min of withdrawals from the "1,500-foot" sand to the "2,800-foot" sand $12 \mathrm{mi}$ northwest of the industrial district (scenario 3) would have a negligible effect on water levels and chloride concentrations in the "1,500-foot" sand $15 \mathrm{mi}$ to the south-southeast where saltwater is encroaching toward wells in the " 1,500 -foot" sand. Within the "2,800-foot" sand, the area of saltwater encroachment is only $3 \mathrm{mi}$ from increased withdrawals in the "2,800-foot" sand, and water levels would be about 5 feet lower in 2047 than for the "status quo" scenario. A larger hydraulic gradient would cause slightly faster saltwater transport and higher chloride concentrations within this area of the "2,800-foot" sand. 


\section{Introduction}

Fresh groundwater is valued for public and industrial supply in southeastern Louisiana and the greater Baton Rouge area, which includes East and West Baton Rouge, Pointe Coupee, and East and West Feliciana Parishes (fig. 1), subsequently referred to as the "Baton Rouge area." Fresh groundwater in most aquifers beneath the Baton Rouge area is soft, sodium bicarbonate water with a total dissolved-solids concentration of less than about 200 milligrams per liter (mg/L) (Meyer and Turcan, 1955), requiring little treatment for potable use or industrial purposes (Stuart and others, 1994). Withdrawals of this groundwater since the 1940s have lowered water levels and altered groundwater-flow directions in most of the 10 freshwater-bearing aquifers underlying the Baton Rouge area. During 2016, about 177 million gallons per day (Mgal/d) were withdrawn from these aquifers, primarily for public and industrial supply and mostly in East Baton Rouge Parish. The drawdown of groundwater levels has caused saltwater ${ }^{1}$ to encroach into freshwater areas near Baton Rouge. Saltwater encroachment has been detected in seven aquifers, including the "1,500-foot" sand, "2,400-foot" sand, and "2,800-foot" sand in East Baton Rouge Parish (Lovelace, 2007).

Water planners and managers need additional knowledge about the effects of groundwater withdrawals on the rate and pathways of saltwater migration and a tool to assess possible management strategies that could mitigate further saltwater encroachment in the Baton Rouge area. In response to this need, the U.S. Geological Survey (USGS), in cooperation with the Capital Area Groundwater Conservation Commission (Commission); the Louisiana Department of Transportation and Development (DOTD), Public Works and Water Resources Division; and the City of Baton Rouge and Parish of East Baton Rouge, developed the groundwaterflow and saltwater-transport model of the Southern Hills regional aquifer system documented in this report. The model simulates the effects of reported groundwater withdrawals on groundwater flow in the regional aquifer system and the movement of saltwater northward from the Baton Rouge Fault in the "1,500-foot" sand, "2,400-foot" sand, and "2,800-foot" sand in East Baton Rouge Parish. The model simulates historical conditions (through 2016) and the effects of three different pumping scenarios on future groundwater levels and saltwater encroachment. The model (Heywood, 2019) may also be used to evaluate the effectiveness of other modified pumping rates that may affect saltwater encroachment.

${ }^{1}$ For the purposes of this report, saltwater is defined as water containing greater than $250 \mathrm{mg} / \mathrm{L}$ chloride. Concentrations of chloride greater than $250 \mathrm{mg} / \mathrm{L}$ exceed the Secondary Maximum Contaminant Level (SMCL) for drinking water (U.S. Environmental Protection Agency, 2017). SMCLs are established for contaminants that can adversely affect the aesthetic quality of drinking water. At high concentrations or values, health implications, as well as aesthetic degradation, also may exist. SMCLs are not federally enforceable but are intended as guidelines for the States.

\section{Purpose and Scope}

This report documents a groundwater model of the Southern Hills regional aquifer system in southeastern Louisiana and southwestern Mississippi, including descriptions of the hydrogeologic framework, the rates of groundwater withdrawals from each aquifer, the aquifer and confining-unit hydraulic properties estimated by model calibration, and the simulation of chloride transport in the "1,500-foot" sand, "2,400-foot" sand, and "2,800-foot" sand in the Baton Rouge area. Although the model is designed primarily to simulate saltwater encroachment in the "1,500-foot" sand, "2,400-foot" sand, and " 2,800 -foot" sand, simulation of groundwater flow through overlying and intervening hydrogeologic units improves the simulation in the aquifers of principal concern by accounting for flow between aquifers through confining units and multiaquifer wells, both of which affect aquifer water levels. The simulated aquifer-system water budget and the effects of groundwater withdrawals on water levels, flow directions, and the movement of saltwater in the "1,500-foot" sand, "2,400-foot" sand, and "2,800-foot" sand are described. Three scenarios described herein simulate the future water levels and chloride concentrations within the "1,500-foot" sand, "2,400-foot" sand, and "2,800-foot" sand if groundwater withdrawals were to continue at 2016 rates or if one of two proposed modifications to the 2016 withdrawals from the " 1,500 -foot" sand or " 2,800 -foot" sand were to be enacted. All model input data and output for the three scenarios are available from Heywood (2019).

\section{Previous Investigations}

Several previous reports have included background data on the geologic, hydraulic, and water-quality characteristics of freshwater-bearing aquifers in the Baton Rouge area (Howson, 1919; Meyer and Turcan, 1955; Morgan, 1961). Morgan and Winner (1964) documented known areas of saltwater in aquifers underlying East and West Baton Rouge Parishes and estimated the rates of saltwater movement toward areas of large groundwater withdrawals in an industrial district and toward public-supply pumping stations. Whiteman (1979) included a detailed discussion of saltwater encroachment in the "600-foot" sand and "1,500-foot" sand and discussions of saltwater in other aquifers. Whiteman (1979) also documented the existence of the east-west trending Baton Rouge Fault as a leaky hydrologic barrier that limits northward movement of saltwater in aquifers in the Baton Rouge area. Buono (1983) described the freshwater-bearing aquifers in the northern parishes of southeastern Louisiana (including those in the Baton Rouge area) and the updip equivalent aquifers in Mississippi as an interdependent system, which he named the "Southern Hills regional aquifer system" (fig. 2). Griffith (2003) presented hydrogeologic cross sections of the freshwater aquifers in southeastern Louisiana, which 


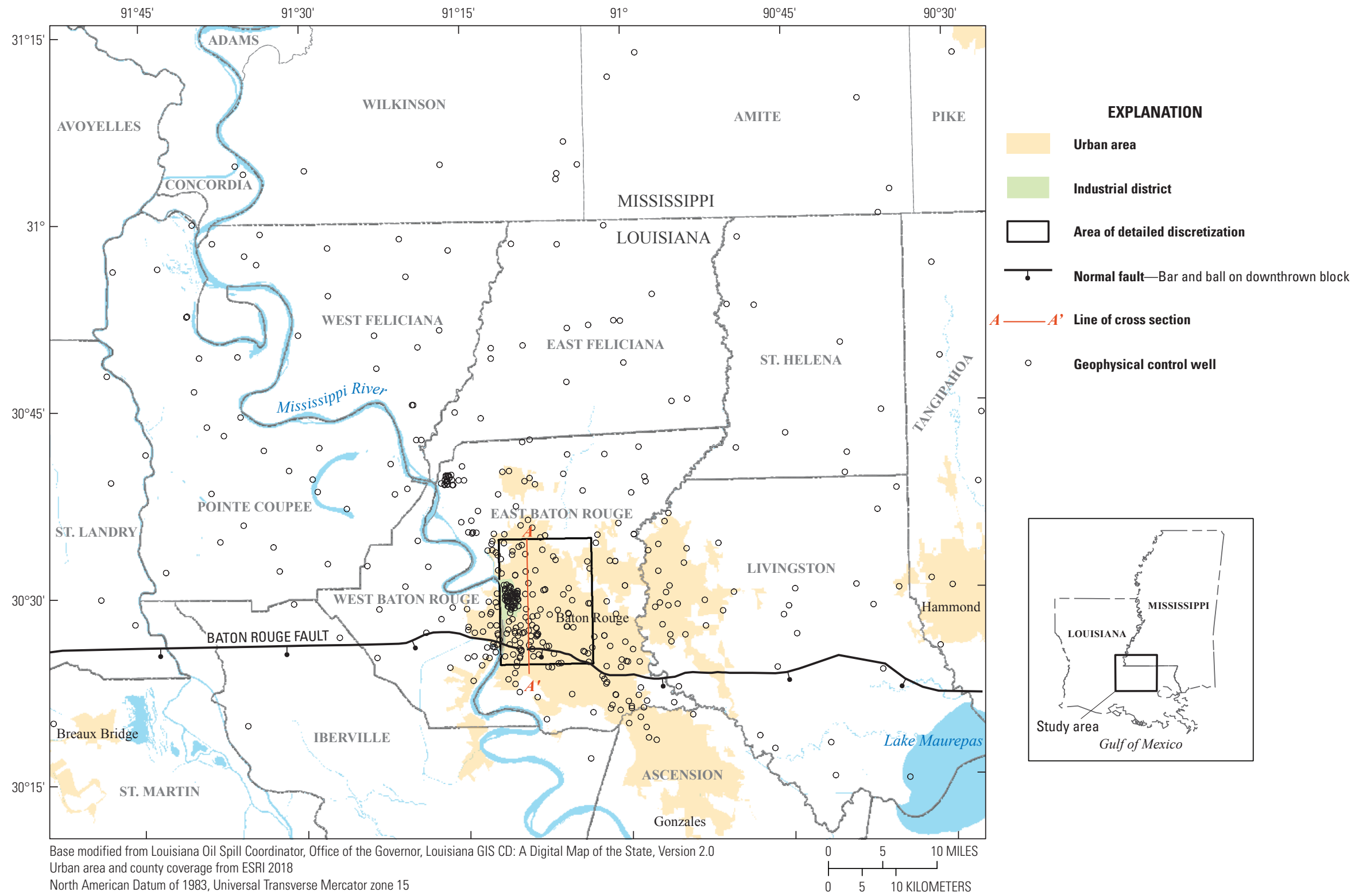

Figure 1. Location of the study area, the Baton Rouge Fault, and geophysical control wells in southeastern Louisiana and southwestern Mississippi. 


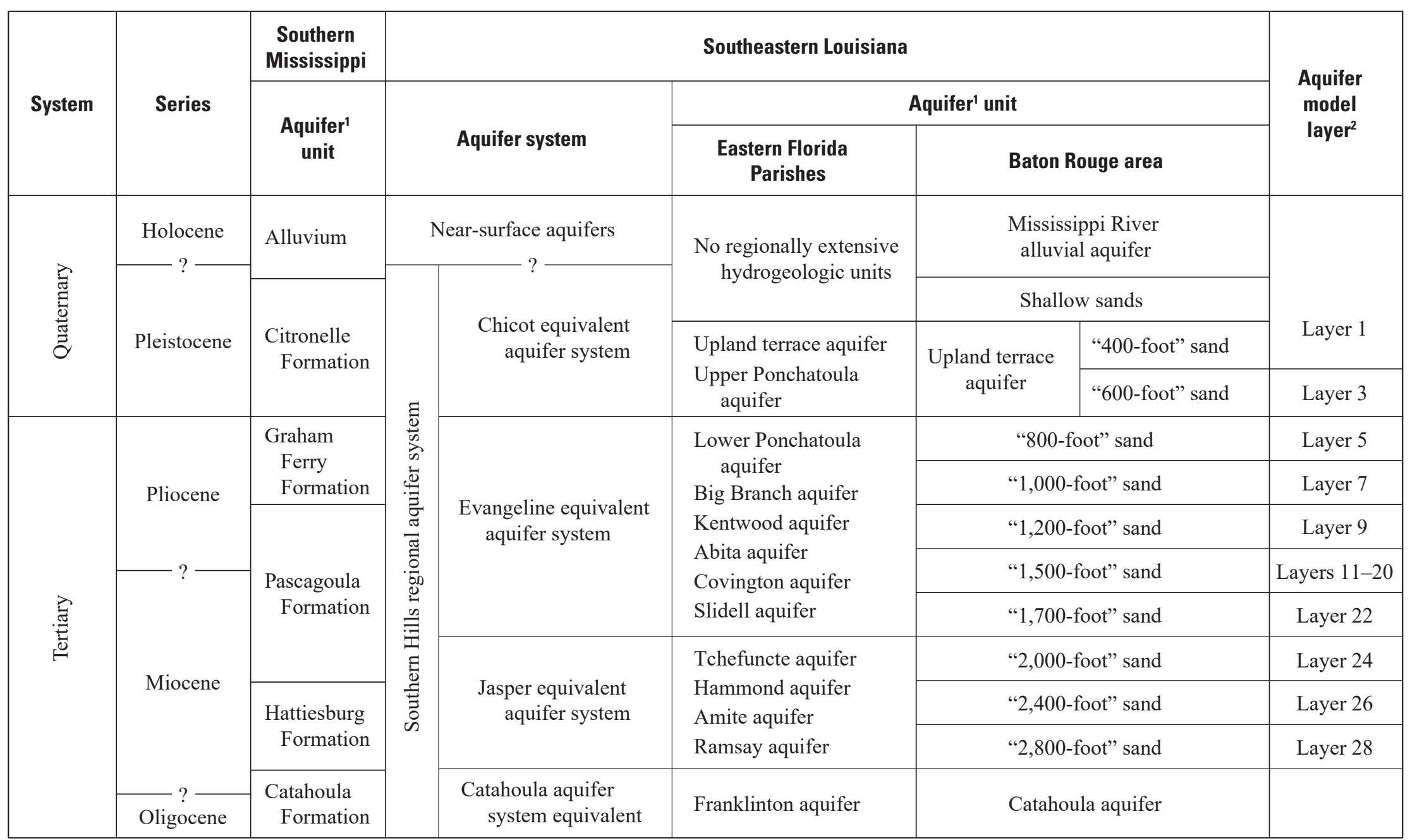

'Aquifers in southern Mississippi and southeastern Louisiana are separated by unnamed discontinuous confining units.

${ }^{2}$ Aquifer model layers are separated by confining model layers except model layers $11-20$. Model layer 28 is the bottom model layer.

Figure 2. Aquifers and aquifer systems in southern Mississippi and southeastern Louisiana and corresponding model layers (modified from Buono, 1983; Stuart and others, 1994; Lovelace and Lovelace, 1995; and Griffith, 2003). 
he described as a sequence of complexly interbedded, interconnected, lenticular (lens shaped), alluvial, freshwaterbearing, clayey, sandy, and graveliferous strata. Morgan and Winner (1964), Whiteman (1979), Tomaszewski (1996), and Lovelace (2007) documented the occurrence of saltwater and increasing chloride concentrations within various aquifers in the Baton Rouge area.

In 1975, the USGS began a cooperative program with the DOTD and the Commission to analyze groundwater flow by using groundwater models of aquifers in the Baton Rouge area, including the " 400 -foot" sand and " 600 -foot" sand (Kuniansky, 1989), the "1,200-foot" sand (Halford and Lovelace, 1994), the "1,500-foot" sand and " 1,700 -foot" sand (Huntzinger and others, 1985), and the "2,000-foot" sand (Torak and Whiteman, 1982) in the Baton Rouge area. Under the USGS regional aquifer-system analysis program, the hydrogeologic framework, groundwater chemistry, and regional flow patterns in the freshwater aquifers along the northern coast of the Gulf of Mexico in Louisiana and parts of Texas and Mississippi were described, and groundwater-flow models were developed to simulate regional flow patterns (Martin and Whiteman, 1990). Recent groundwater models of the Baton Rouge area have simulated flow through all of the Baton Rouge sands, with particular emphasis on saltwater transport in the "2,000-foot" sand and the "1,200-foot" sand (Heywood and others, 2014, 2015)

\section{Study Area Description}

The study area coincides with the groundwater-model domain, which encompasses about 6,600 square miles $\left(\mathrm{mi}^{2}\right)$ in southeastern Louisiana and southwestern Mississippi (fig. 1) and extends southward from about 25 miles (mi) north of the Mississippi State line to Gonzales, La., in the south and eastward from Breaux Bridge, La., in the west to Hammond, La., in the east. In southeastern Louisiana, all or parts of Ascension, Avoyelles, Concordia, East and West Baton Rouge, East and West Feliciana, Iberville, Livingston, Pointe Coupee, St. Helena, St. Landry, St. Martin, and Tangipahoa Parishes are in the study area. In Mississippi, all or parts of Adams, Amite, Pike, and Wilkinson Counties are in the study area.

The terrain in the study area varies from forested rolling hills in the north to flat lowlands and swamps in the south. The Mississippi River Valley dominates the setting near the western and southern boundaries of the study area. Landsurface altitudes range from zero to more than 450 feet (ft) (Calhoun and Frois, 1997). The climate is subtropical, warm, and temperate, with an average annual temperature of 68 degrees Fahrenheit $\left({ }^{\circ} \mathrm{F}\right)$ and an average annual rainfall of 61 inches (National Oceanic and Atmospheric Administration, 1995).

About 1 million people live within the study area, with the largest population in the Baton Rouge metropolitan area (U.S. Census Bureau, 2010). All of the public water supplied in the Baton Rouge area in 2010 was groundwater (Sargent,
2011). Several industrial facilities, primarily located along the Mississippi River, also utilize the groundwater resources in the study area. In addition, groundwater supplies about 84 percent of agricultural water use in the study area (Sargent, 2011).

\section{Horizontal Datum and Projection Systems}

The geographic coordinates of database features, such as wellhead locations, and geographic information system (GIS) data used in the model are referenced to the North American Datum of 1983 (NAD 83). To represent model finite-difference-cell areas accurately, GIS coverages of the model finite-difference cells and nodes were generated in a Lambert Conformal Conic projection system oriented north-south. The grid coverages were subsequently projected into the Universal Transverse Mercator zone 15 coordinate system used for well, hydrogeologic framework, and waterlevel coverages, and therefore appear slightly rotated in the Universal Transverse Mercator projection of map figures in this report. Projection and coordinate system details are included in Heywood (2019).

\section{Hydrogeology}

Aquifers containing freshwater in the Baton Rouge area are generally part of the fluvial-deltaic Southern Hills regional aquifer system and include the Mississippi River alluvial aquifer, the shallow sands of the Baton Rouge area, the Upland terrace aquifer; the " 400 -foot" sand, " 600 -foot" sand, "800-foot" sand, "1,000-foot" sand, "1,200-foot" sand, "1,500-foot" sand, "1,700-foot" sand, "2,000-foot" sand, "2,400-foot" sand, and "2,800-foot" sand of the Baton Rouge area (hereafter referred to as the "Baton Rouge sands"); and the Catahoula aquifer (Meyer and Turcan, 1955; Morgan, 1961; Buono, 1983; Griffith, 2003). The Mississippi River alluvial aquifer and the shallow sands of the Baton Rouge area are the shallowest aquifers in the Baton Rouge area. Deeper aquifers in the Baton Rouge area include the Baton Rouge sands, which are named for their depth of occurrence in the Baton Rouge industrial district (fig. 1), and the Catahoula aquifer. The aquifers in the Baton Rouge area have been correlated with aquifers in southern Mississippi and in Louisiana parishes east of the study area and have also been grouped on the basis of correlative units in southwestern and central Louisiana into the Chicot equivalent, Evangeline equivalent, Jasper equivalent, and Catahoula equivalent aquifer systems (Stuart and others, 1994). Although the Catahoula aquifer contains freshwater in some areas, it is generally too deep and contains too much saltwater to be an economically viable water resource in the Baton Rouge area (Griffith, 2003).

Freshwater-bearing aquifers in the Baton Rouge area range in composition from very fine to coarse sand with some pea- to cobble-sized gravel (Griffith, 2003) and are sufficiently 
Simulation of groundwater flow and chloride transport in the "1,500-foot," "2,400-foot," and "2,800-foot" sands

permeable to yield economically substantial quantities of water to wells (Bates and Jackson, 1984). The aquifers are separated by confining units composed of lithologies ranging from solid clays to sandy and silty clays that impede vertical groundwater flow. The freshwater aquifers and intervening confining units in the Baton Rouge area, together with the updip equivalent units in southwestern Mississippi, form a thickening wedge that dips to the south and southwest toward the Gulf of Mexico. The confining units generally pinch out northward, and deeper aquifers coalesce with overlying surficial aquifers.

Because the aquifers are relatively shallow in the northern part of the study area near Mississippi, infiltration of precipitation recharges the aquifer system in these topographically higher areas. Interconnection of the aquifers permits the shallow recharged groundwater to seep into the deeper aquifers as it flows south toward the Baton Rouge area. Kuniansky (1989) estimated a range from 0.2 to 4.6 inches per year for deep regional aquifer recharge in the Baton Rouge area. Groundwater velocities range from a few tens of feet per year to several hundreds of feet per year (Buono, 1983).

The "1,500-foot" sand, "2,400-foot" sand, and " 2,800 foot" sand generally dip and thicken to the south and consist of single or multiple intervals of fine-to-medium sand. Where these aquifers contain multiple sand intervals, the sand intervals are separated by clays. The " 1,500 -foot" sand is about 1,500 $\mathrm{ft}$ below land surface in the Baton Rouge area north of the Baton Rouge Fault but is displaced downward about $300 \mathrm{ft}$ at the fault (fig. 3). Similarly, the "2,400-foot" sand and "2,800-foot" sand are about 2,400 and 2,800 ft below land surface, respectively, north of the Baton Rouge Fault but are displaced downward at the fault.

\section{Baton Rouge Fault}

The Baton Rouge Fault extends across the southern part of the study area (fig. 1) and is part of a series of east-west trending faults in southern Louisiana (Murray, 1961; Hanor, 1982; Griffith, 2003). The location of the Baton Rouge Fault was documented in the 1960s and 1970s after the importance of the fault as a barrier to groundwater flow in the aquifers in the Baton Rouge area became apparent (Meyer and Rollo, 1965; Whiteman, 1979). McCulloh (1991) mapped the detailed location of the surface expression of faults through East Baton Rouge Parish. Within the study area, the Baton Rouge Fault dips to the south at angles between about 65 and 70 degrees (Durham and Peeples, 1956; Smith and Kazmann, 1978; Whiteman, 1979; Roland and others, 1981; Hanor, 1982; McCulloh, 1991; Griffith, 2003, 2006).

Sediment deformation and displacement of sedimentary layers across the Baton Rouge Fault reduce the hydraulic connections between aquifers, thereby impeding horizontal groundwater flow, which causes substantial changes in both water levels and water quality across the fault (Whiteman, 1979). The displacement of aquifers across the fault ranges from about $20 \mathrm{ft}$ near the ground surface to about $300 \mathrm{ft}$ at altitudes of about $-1,600$ to $-3,000 \mathrm{ft}$.

\section{Occurrence and Movement of Saltwater}

Groundwater investigations conducted during the 1960s identified a freshwater-saltwater interface located near the Baton Rouge Fault (Morgan and Winner, 1964; Rollo, 1969). Prior to groundwater development in the 1940s, fresh groundwater flowed from recharge areas in Mississippi southward toward the fault and then upward to discharge at springs. This groundwater-flow pattern caused aquifers north of the fault to generally contain freshwater, whereas they may contain saltwater south of the fault. Although saltwater is more prevalent south of the Baton Rouge Fault, freshwater is also found beneath some areas south of the fault, such as West Baton Rouge Parish, where the "1,500-foot" sand contains freshwater areas. In the Baton Rouge area, the base of freshwater is deeper on the north side than the south side of the fault by about 1,100-2,600 ft. The altitude of the base of freshwater ranges between about $-1,500$ and $-3,500 \mathrm{ft}$ north of the fault and between about -200 and $-1,000 \mathrm{ft}$ south of the fault (Smoot, 1988; Griffith, 2003). Aquifer tests conducted across the fault in the vicinity of Baton Rouge have indicated that the fault impedes groundwater flow (Whiteman, 1979).

Large groundwater withdrawals north of the fault in Baton Rouge, primarily for public supply and industrial use, have lowered water levels and created gradients conducive to the movement of saltwater from the south side of the fault into previously freshwater areas north of the fault (Whiteman, 1979; Tomaszewski, 1996). In aquifers above the "2,800-foot" sand and Catahoula aquifers, most saltwater presently north of the fault moved there in response to the groundwater withdrawals in the Baton Rouge area.

In the "1,500-foot" sand, saltwater has migrated north from the fault in an area where the bottom of that aquifer is at a lower altitude and relatively thicker than in surrounding areas beneath Baton Rouge (fig. 3). This saltwater threatens municipal-supply wells located about $3 \mathrm{mi}$ north of the fault. A "scavenger well" was installed $0.7 \mathrm{mi}$ south of these wells to intercept the encroaching saltwater. This "scavenger well," which commenced operation during 2014, is actually two wells: one that extracts the saltier groundwater near the base of the "1,500-foot" sand, and another that extracts fresher groundwater toward the top of the aquifer. These wells extracted the saltier and fresher fractions at average rates of 247 and 367 gallons per minute (gal/min), respectively, during 2016.

Saltwater encroachment in the "2,400-foot" sand has been relatively limited, and only observed in wells within about $0.5 \mathrm{mi}$, north of the fault. In contrast to overlying aquifers, saltwater was probably present north of the fault within the "2,800-foot" sand beneath the Baton Rouge area prior to groundwater development (Tomaszewski, 1996) and has migrated toward areas of industrial groundwater 


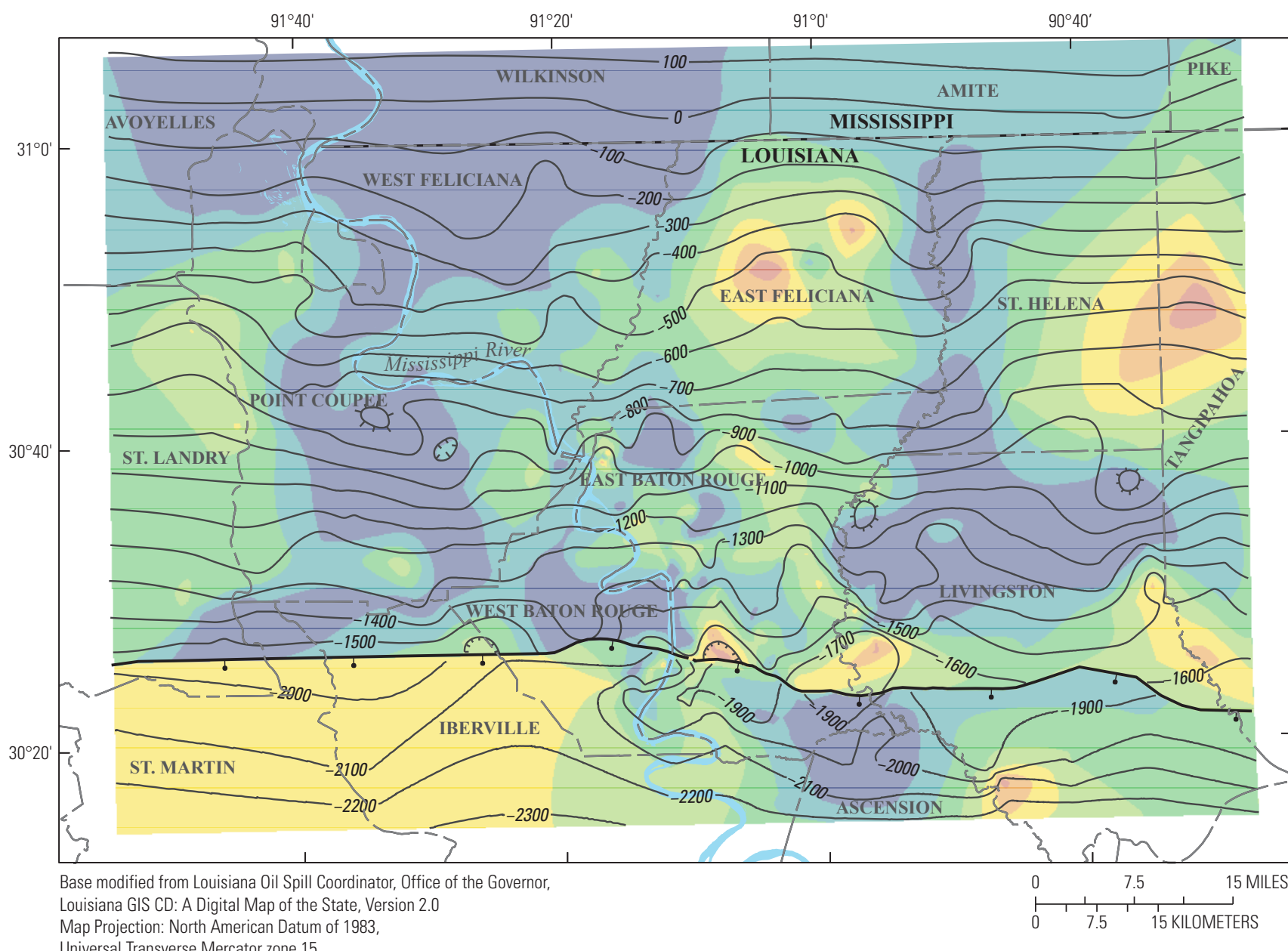

EXPLANATION

\section{Simulated aquifer thickness, in feet}

$0-50$

$51-100$

$101-150$

$151-200$

201-250

$251-300$

$301-350$

-100- Simulated altitude contour-Shows altitude of base of aquifer north or south of Baton Rouge fault. Contour interval 100 feet. Datum is National Geodetic Vertical Datum of 1929

- Baton Rouge Fault—bar and ball on downthrown block

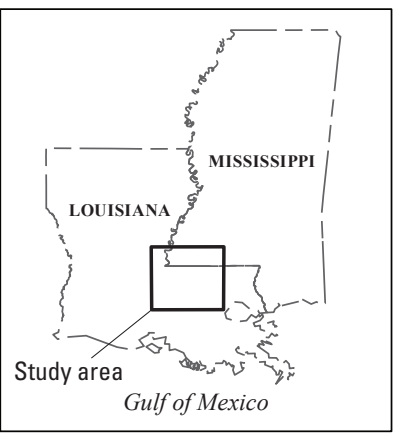

Universal Transverse Mercator zone 15

Figure 3. Thickness and altitude of the base of the "1,500-foot" sand of the Baton Rouge area in the groundwater model domain in southeastern Louisiana and southwestern Mississippi. 
withdrawals within that aquifer farther to the north. If groundwater withdrawals from the Baton Rouge sands continue at the historical rates, saltwater encroachment within these sands will probably continue in the Baton Rouge area (Tomaszewski, 1996).

\section{Hydrogeologic Framework}

A three-dimensional hydrogeologic framework was constructed to delineate the extents and variable thicknesses of aquifers and confining units in the study area. The hydrogeologic framework represents the entire sequence of aquifers and confining units in the Southern Hills regional aquifer system above the Catahoula equivalent aquifer system (fig. 2). The Catahoula equivalent aquifer system was omitted from the framework because in the study area it contains mostly saltwater and is little used, and because few geophysical logs were available to delineate its extent and thickness.

The top altitudes and thicknesses of each aquifer and confining unit layer were interpreted by using geophysical logs (long- and short-normal resistivity, gamma, and spontaneous potential) from 463 stratigraphic control wells. Drillers' logs were compared with the geophysical logs when possible. Most geophysical logs were recorded during installation of water-observation or supply wells and were archived at the USGS office in Baton Rouge, La. Several oil and gas test-well logs obtained from the Louisiana Department of Natural Resources were also utilized. Previous stratigraphy reports in the study area guided the placement of aquifer unit contacts (Meyer and Turcan, 1955; Rollo, 1969; Buono, 1983; Kuniansky and others, 1989; Griffith, 2003. The general configuration of aquifer and confining units changes laterally outside the detailed portion of the model area, including the subcropping of units toward the north into the Upland terrace aquifer and Mississippi River alluvium. These hydrogeologic units were extended from the Baton Rouge area by using log correlation and the stratigraphic correlations tabulated by Lovelace and Lovelace (1995) and mapped by Griffith (2003). Because the Southern Hills regional aquifer system is composed of fluvial deposits, the sandy and more permeable layers locally coalesce throughout the model area. Where two discrete aquifers merge into a single aquifer, a 1-ft-thick confining layer was inserted to maintain continuity of the hydrogeologic unit definitions throughout the study area. The 1 -ft confining units were placed at altitudes that maintain existing aquifer-thickness proportionalities at nearby lithologic-control wells where the aquifers are separated by a confining unit. Where no proximal lithologic-control wells were available, the discrete aquifer layers were assigned equal fractions of the total aquifer thickness. The deposits of the Mississippi River alluvial aquifer, which are connected to the " 400 -foot" sand west of the Mississippi River in the Baton Rouge area (Kuniansky and others, 1989; Griffith, 2003), were included with the "400-foot" sand as part of the upper layer of the model.

Raster (matrix of values) representations of the thickness and altitude of the top of each hydrogeologic unit were generated by using GIS software. The rasters of hydrogeologic-unit-top altitudes were generated by natural-neighbors interpolation between control points. The rasters of hydrogeologic-unit thickness were generated by first constructing triangulated irregular network surfaces, which allowed manual delineation of areas where particular hydrogeologic units were interpreted to be absent. The triangulated irregular network surfaces were subsequently sampled and converted to rasters by using natural-neighbors interpolation. Aquifer thickness and altitude values were extrapolated from control points to the perimeter of the model domain where necessary. Because the stratigraphiccontrol wells had various depths, some hydrogeologicunit-top altitudes were undefined at certain control points. The lack of control points in some areas caused erroneous intersections of the interpolated hydrogeologic-unit layers at depth in some of those areas. This problem was remedied by (1) generating initial rasters from the control data, (2) extracting hydrogeologic-unit altitudes from these rasters for all the stratigraphic control points, (3) adjusting the top and base altitudes of the intersecting layers incrementally, and (4) regenerating the altitude raster surfaces by using the adjusted altitudes at the control points. For observation or supply wells known to be screened in a particular aquifer, the aquifer top and base altitudes were not adjusted in order to maintain the well-screen altitude relative to the top and base altitude of the aquifer.

Correlation across the Baton Rouge Fault is uncertain (Griffith; 2003), and the apparent displacement of hydrogeologic units may be due to differences in sediment deposition on either side of the fault (Smith, 1979). Previous reports were used to help constrain the displacement of the hydrogeologic units across the fault (Rollo, 1969; Smith, 1979; Whiteman, 1979; McCulloh, 1991; Griffith, 2003, 2006). Separate top-altitude and thickness rasters were generated for areas north and south of the Baton Rouge Fault; these surfaces were joined at the interpreted fault line. The difference in hydrogeologic-unit-top altitudes across this line represent vertical fault displacement.

Figure 4 illustrates the hydrogeologic framework in cross section in the Baton Rouge area. The top of the hydrogeologic framework is the interpreted top of the "400-foot" sand and interconnected aquifers that include the Mississippi River alluvial aquifer, shallow sands, and Upland terrace aquifer. The bottom of the hydrogeologic framework is the base of the "2,800-foot" sand. The aquifers and confining units are represented by 28 layers, numbered from the top to the bottom (fig. 2). Layers 1, 3, 5, 7, 9, 11-20, 22, 24, 26, and 28 make up the aquifer layers (fig. 4). Layers 2, 4, 6, 8, 10, 21, 23, 25, and 27 make up confiningunit layers that separate the aquifer layers (fig. 4). 


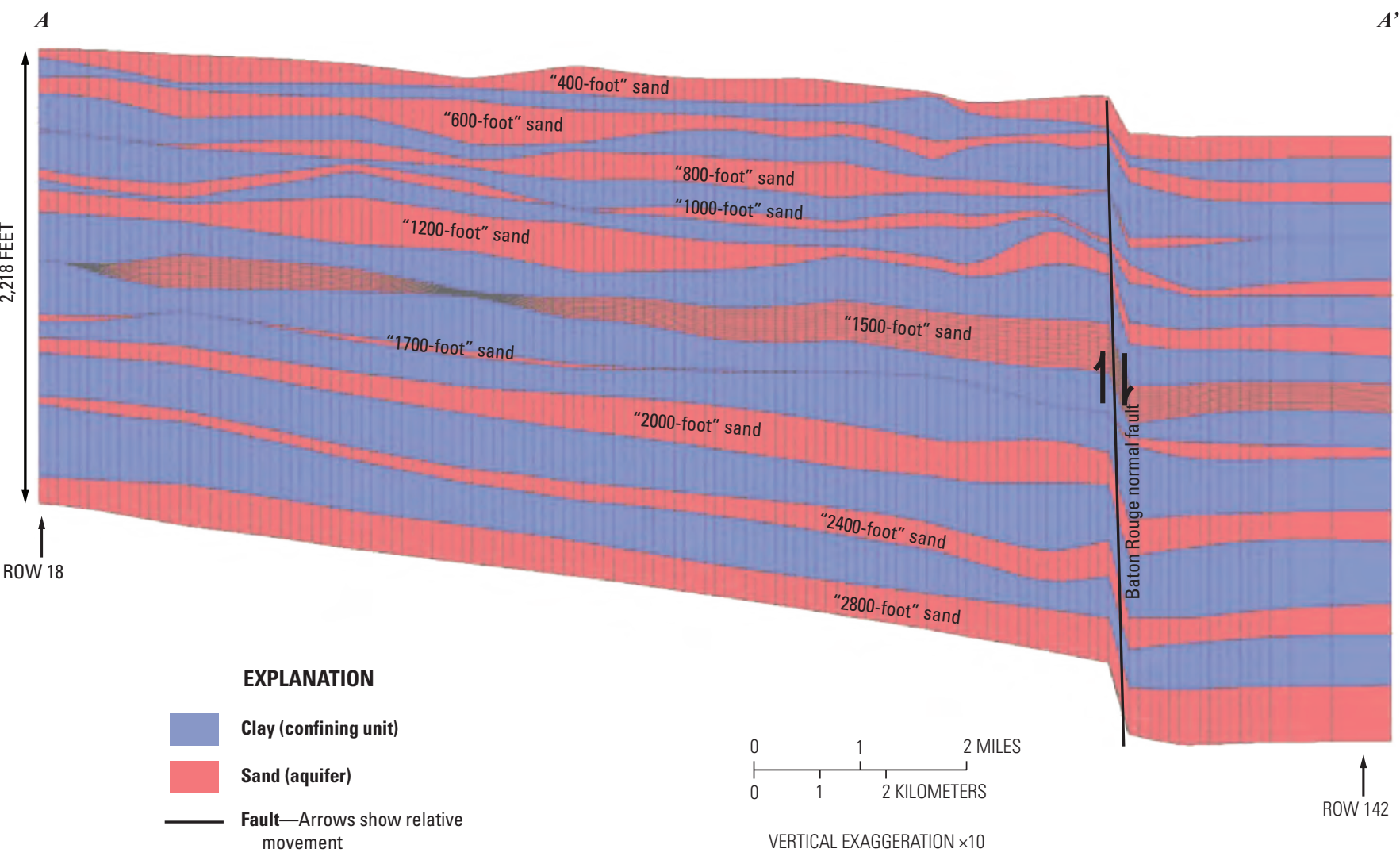

Figure 4. North-to-south cross section along model column 43 showing aquifers, confining units, and finite-difference discretization.

\section{Groundwater Withdrawals}

Groundwater withdrawals from the Baton Rouge sands commenced in the 1910s and increased during the 1930s to supply the needs of the petroleum-refining chemical industries. These early withdrawals were initially from the " 400 -foot" and "600-foot" sands, and from deeper aquifers by the 1930 s. Because records of groundwater withdrawals prior to 1940 are sparse and difficult to associate with accurate well locations, they were not compiled for this study.

Withdrawal records for 722 wells in Louisiana from the period 1940 through 2016 were compiled from the digital databases and paper records of the USGS and the Commission. Most of these withdrawal records were reported by personnel at public-supply and industrial facilities. Withdrawal rates for wells or facilities inventoried on a 5-year basis since 1960 were obtained from USGS water-use records. Sporadic annual withdrawal data from 1940 to 1975 for some facilities in the Baton Rouge area also were obtained from USGS water-use records. Annual withdrawal rates from wells in East and West Baton Rouge, East and West Feliciana, and Pointe Coupee Parishes from 1975 through 2012 were obtained from the Commission water-use database (Shawn Scallan, Capital Area
Ground Water Conservation Commission, written commun., 2013). Annual withdrawal rates from about 1988 through 2016 for facilities that withdrew an average of $1 \mathrm{Mgal} / \mathrm{d}$ or greater and were located in other parishes in the study area were obtained from USGS water-use records.

Where only facility-specific withdrawals were available, well-specific rates were typically estimated by evenly distributing the withdrawals reported for each facility among the active wells at that facility. Well registration, construction, and plugging or abandonment data from USGS, DOTD, Commission, and Louisiana Department of Natural Resources (DNR) databases were used to determine when specific wells were utilized at the facilities where facilityspecific withdrawals were reported. Annual withdrawals were estimated or interpolated for some wells having intermittent data. In some cases, facilities were contacted to verify pumping rates and well activity during different periods.

Well-construction data were obtained from USGS and DNR databases and include borehole, screen, and casing diameters; screen intervals; pump depth; location; and landsurface altitude. Missing or inadequate information was estimated or adjusted by using ancillary information from topographic maps, well logs, the specifications of nearby 
wells or wells with identical ownership, well schedules, and thickness data from the hydrogeologic framework. Some wells with inadequate well-construction information and probable withdrawal rates less than $0.01 \mathrm{Mgal} / \mathrm{d}$ were omitted. Wells with screen-interval records corresponding to confining-unit intervals in the hydrogeologic framework were assumed to be screened in an appropriate adjacent aquifer.

During 2016, the total reported groundwater withdrawals from aquifers in the study area averaged about $177 \mathrm{Mgal} / \mathrm{d}$, of which about $168 \mathrm{Mgal} / \mathrm{d}$ (95 percent) was withdrawn from the "400-foot," "600-foot," "800-foot," "1,000-foot," "1,200-foot," "1,500-foot," "1,700-foot," "2,000-foot," "2,400-foot," and "2,800-foot" sands. Figure 5 illustrates the general increase in groundwater withdrawals through time, particularly from the deeper aquifers. Until the early 1950 s, groundwater withdrawals were principally from the " 400 -foot" sand and the " 600 -foot" sand. Since the 1950s, deeper aquifers such as the "1,200-foot" sand, "1,500-foot" sand, "2,000-foot" sand, "2,400-foot" sand, and "2,800-foot" sand have increasingly supplied most of the groundwater used in the Baton Rouge area.
Groundwater withdrawals from the "1,500-foot" sand of the Baton Rouge area averaged 21.5 Mgal/d during 2016. Most of these withdrawals are for public supply and are located 2-3 mi north of the Baton Rouge Fault (fig. 6) and southeast of the Baton Rouge industrial district. Most withdrawals not used for public supply occur north of the industrial district. Some groundwater (2.48 Mgal/d during 2016) was withdrawn from the "1,500-foot" sand south of the Baton Rouge Fault in a freshwater-bearing area west of the Mississippi River in West Baton Rouge Parish.

Groundwater withdrawals from the "2,400-foot" sand of the Baton Rouge area are primarily utilized for industrial and public-supply needs and averaged $26.92 \mathrm{Mgal} / \mathrm{d}$ during 2016. Wells supplying these withdrawals are located north of the Baton Rouge Fault throughout East Baton Rouge Parish (fig. 7).

The "2,800-foot" sand of the Baton Rouge area has annually supplied the greatest quantity of groundwater amongst the Baton Rouge sands since the year 2000 (fig. 5), and withdrawals averaged $32.82 \mathrm{Mgal} / \mathrm{d}$ during 2016. Wells supplying these withdrawals are generally located farther north (fig. 8) than those screened in overlying aquifers, because the

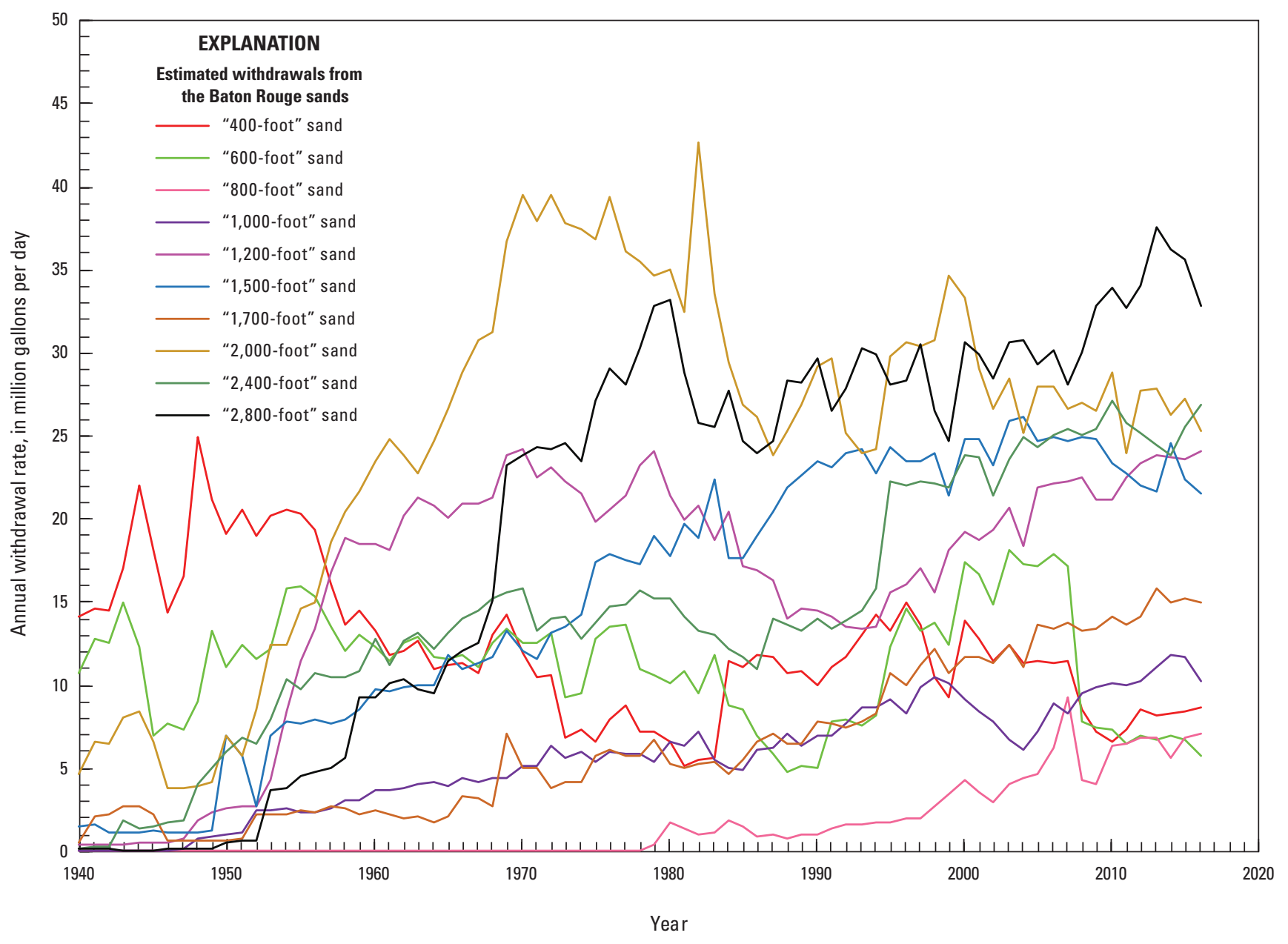

Figure 5. Estimated withdrawals from the Baton Rouge sands, 1940-2016. 


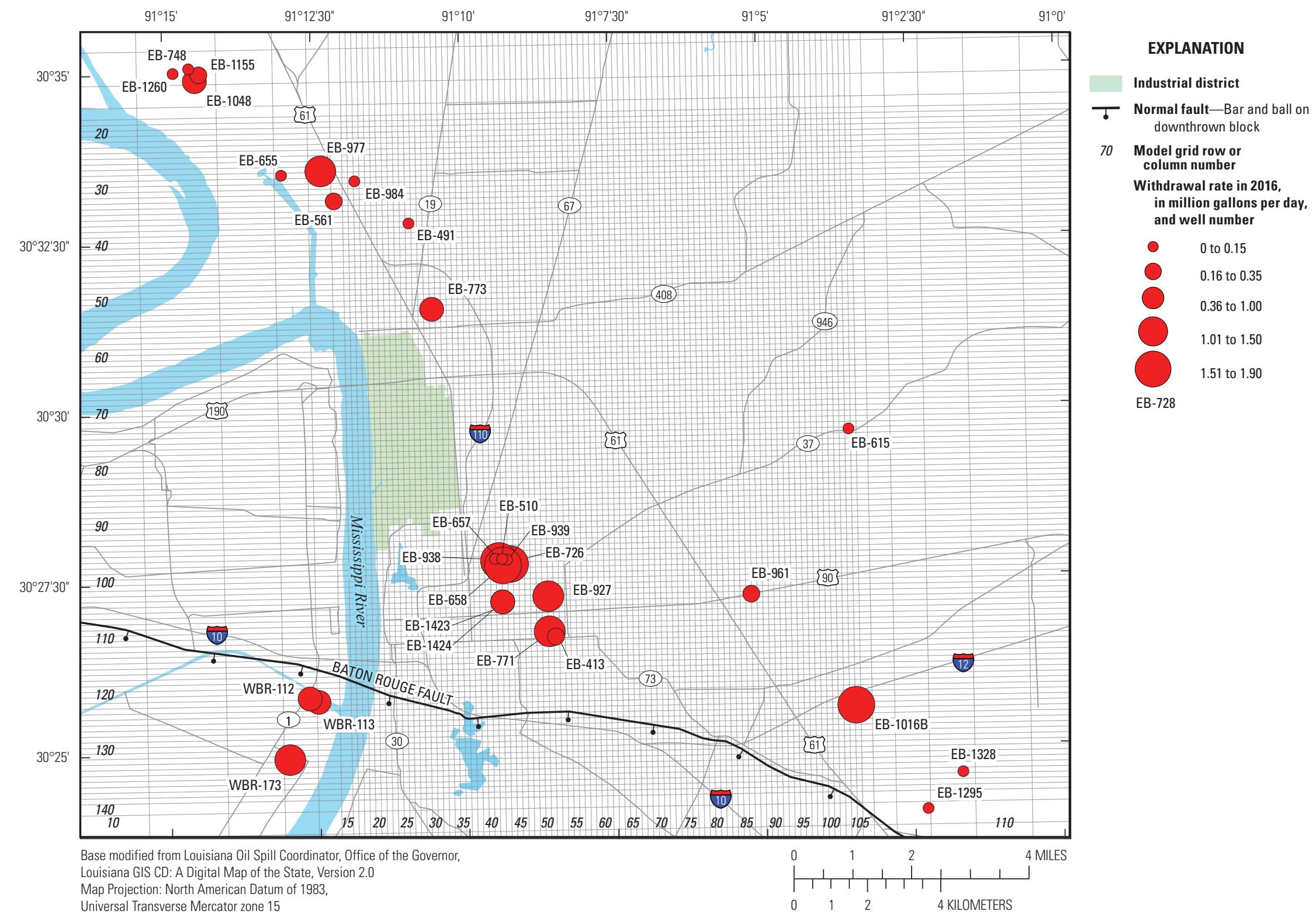

Figure 6. Average daily withdrawal rate during 2016 from wells screened in the "1,500-foot" sand of the Baton Rouge area and located at or near the city of Baton Rouge in southeastern Louisiana. 


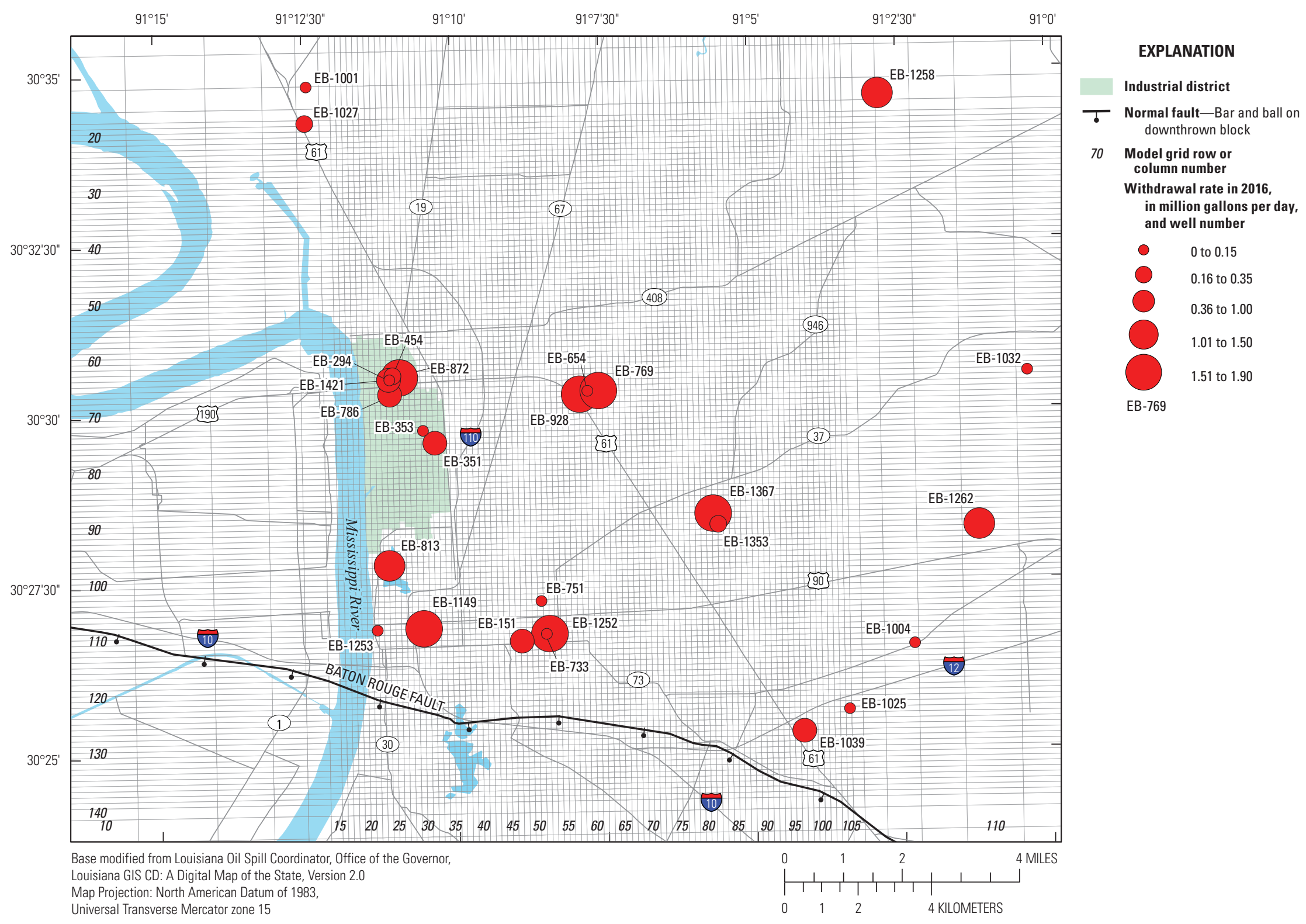

Figure 7. Average daily withdrawal rate during 2016 from wells screened in the "2,400-foot" sand of the Baton Rouge area and located at or near the city of Baton Rouge in southeastern Louisiana. 


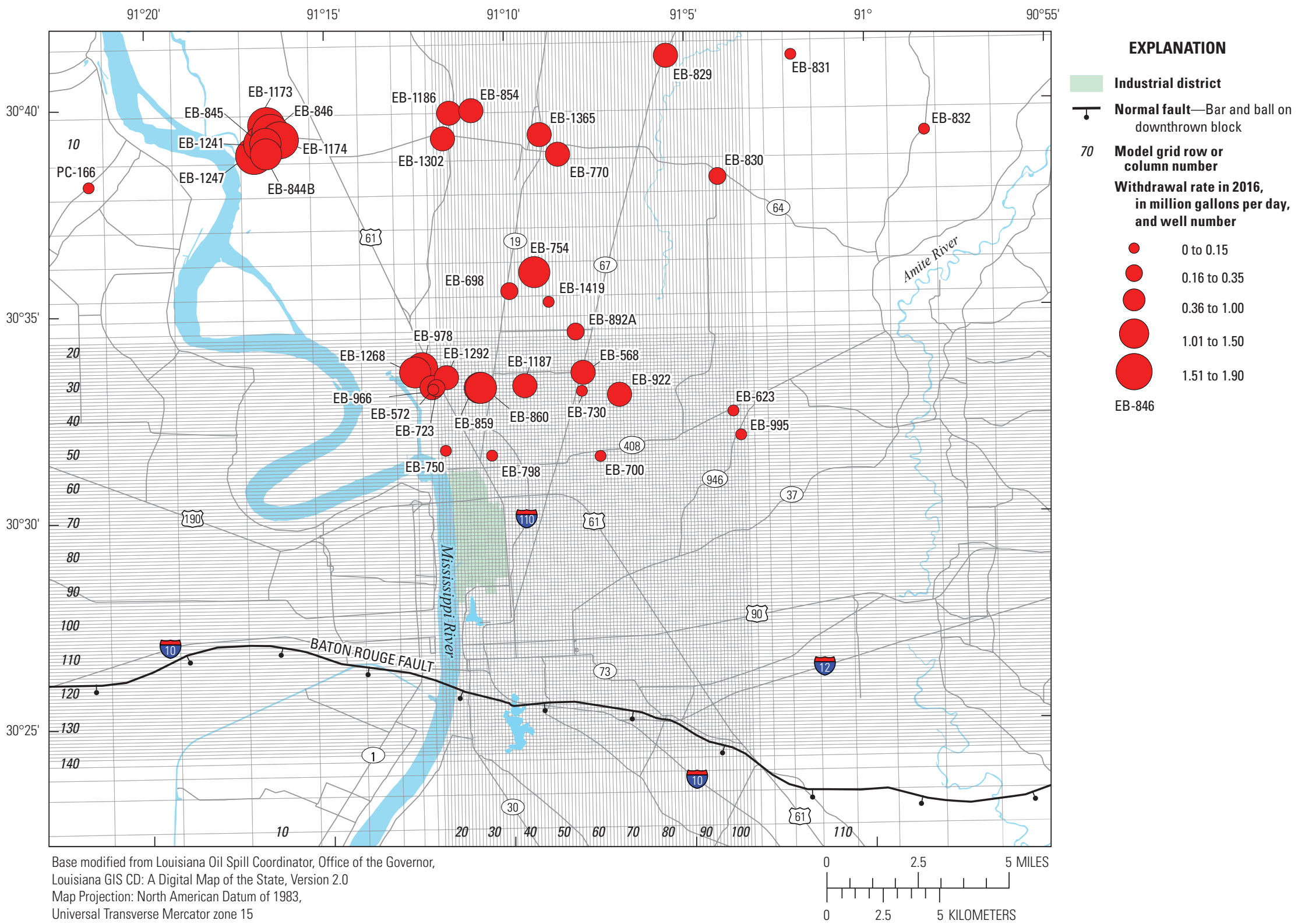

Figure 8. Average daily withdrawal rate during 2016 from wells screened in the "2,800-foot" sand of the Baton Rouge area and located at or near the city of Baton Rouge in southeastern Louisiana. 
portion of the "2,800-foot" sand within approximately 5 mi of the Baton Rouge Fault contains brackish groundwater, with solute concentrations that generally increase southward toward the fault. Industrial withdrawals from the "2,800-foot" sand are concentrated in an area located about 12 mi northwest of the industrial district and near lat $30^{\circ} 39^{\prime} \mathrm{N}$., long $91^{\circ} 16.5^{\prime} \mathrm{W}$. (fig. 8).

\section{Simulation of Groundwater Flow and Chloride Transport}

The model documented in this report is similar to models previously documented by Heywood and others $(2014,2015)$. Differences from the previous versions include (1) refinement of the hydrogeologic framework to represent the " 400 -foot" sand, "600-foot" sand, and "800-foot" sand as separate aquifers; (2) refinement of the vertical finite-difference discretization within the "1,500-foot" sand; (3) refinement of the horizontal finite-difference discretization to provide more detail in the area of transport within the "2,800-foot" sand; (4) use of the MODFLOW Layer Property Flow package; (5) specification of groundwater withdrawals from the "600-foot" and "800-foot" sands; (6) specification of reported annual groundwater withdrawals through 2016; (7) expansion of the solute-transport domain to the area encompassed by the flowmodel domain; and (8) recalibration of model parameters to water levels observed through 2016.

Whereas MODFLOW (Harbaugh, 2005) solves the constant-density groundwater-flow equation, SEAWAT (Langevin and others, 2007) iteratively solves equations that represent variable-density groundwater flow and advectivedispersive mass transport. The highest chloride concentration measured north of the Baton Rouge Fault within the "1,500-foot" sand, "2,400-foot" sand, or "2,800-foot" sand has been $2,000 \mathrm{mg} / \mathrm{L}$, or about 10.3 percent of the seawater chloride concentration, implying a groundwater density at that location only 0.3 percent greater than freshwater. Some groundwater-withdrawal wells in the Baton Rouge area are screened in more than one of the Baton Rouge sands. The Multi-Node Well package, MNW2 (Konikow and others, 2009), can apportion a well's specified total withdrawal amongst multiple layers in which the well is screened, which can improve the simulation of groundwater withdrawals. Because MODFLOW incorporates MNW2 and executes transient simulations much faster than SEAWAT (when it iteratively solves mass-transport equations), MODFLOW was used to simulate groundwater flow during the model calibration process. After the groundwater-flow model parameters were recalibrated to water levels measured through 2016, saltwater transport was simulated with SEAWAT. Calibration of simulated to measured chloride concentrations required minor modification of parameters representing the hydraulic characteristics of the Baton Rouge Fault where it offsets the "1,500-foot" and "2,400-foot" sands in the Baton Rouge area.

\section{Conceptual Model for Solute Transport}

Groundwater in aquifers above the " 2,800 -foot" sand and north of the Baton Rouge Fault is assumed to have been fresh before substantial groundwater withdrawals began. Within the "2,800-foot" sand, saltwater resided north of the Baton Rouge Fault prior to groundwater withdrawals, with decreasing concentration northward across a 4-mi-wide transition zone that begins 3-5 mi north of the Baton Rouge Fault (Tomaszewski, 1996). The origin of the saltwater encroaching into the "1,500-foot" and "2,400-foot" sands is uncertain, but the saltwater likely flows through permeable sediments that are adjacent on the south side of the Baton Rouge Fault. Although spatial variations in chloride concentration have been observed south of the Baton Rouge Fault and some areas of freshwater exist, a simple representation of the saltwater sources in the "1,500-foot" and " 2,400 -foot" sands is preferable in order to model transport north of the fault with available data. These saltwater sources are located at the bottom of the "1,500-foot" sand and "2,400-foot" sand across, and on the south side of, the Baton Rouge Fault from where elevated chloride concentrations have been observed. In response to groundwater withdrawals north of the Baton Rouge Fault, saltwater south of the fault has moved northward across the hydraulically resistive fault toward areas of groundwater-level decline in these aquifers. Within the "2,800-foot" sand, the preexisting saltwater north of the fault has also moved toward areas of freshwater withdrawals farther north in the " 2,800 -foot" sand.

\section{Spatial Discretization}

The finite-difference model grid was designed with variable grid-cell spacing to (1) provide good spatial resolution in a 98.46- $\mathrm{mi}^{2}$ "detailed area" (fig. 1) where past saltwater migration has occurred, or may occur in the future, within the Baton Rouge sands; (2) locate no-flow model boundaries sufficiently far from the "detailed area" to diminish simulated water-level inaccuracies in that area that may be caused by the no-flow boundaries; and (3) constrain the number of finitedifference calculations so that model execution times remain tractable for the parameter-estimation process.

The finite-difference grid documented herein is similar to that of previous models of the Baton Rouge sands (Heywood and others, 2014, 2015), except it (1) includes 10 finite-difference layers to simulate flow and transport in the "1,500-foot" sand; (2) separates the " 400 -foot" sand, "600-foot" sand, and " 800 -foot" sand into distinct aquifer layers; and (3) increases horizontal resolution (with smaller finite-difference cells) in the areas where saltwater encroachment within the "1,500-foot" sand, "2,400-foot" sand, and "2,800-foot" sand is of concern.

The model grid consists of 28 variable-thickness layers, each containing 147 rows and 120 columns of finitedifference cells. Within the 98.46- $\mathrm{mi}^{2}$ "detailed area" of the 
model grid, greater numerical accuracy is obtained by means of 122 rows and 90 columns of $500 \times 500$ - $\mathrm{ft}$ square cells. The model domain encompasses a total area of $6,529 \mathrm{mi}^{2}$, and it contains 493,920 active cells. The cell areas range from 5.74 acres in the detailed model area to 68,870 acres $\left(107.6 \mathrm{mi}^{2}\right)$ at the northwest corner of the model domain. Model-layer altitudes and thicknesses for each cell were defined by the corresponding aquifer or confining unit (fig. 2) altitude and thickness at the locations of cell centroids.

\section{Horizontal Flow Barriers}

The resistance to groundwater flow across the Baton Rouge Fault as a consequence of sediment deformation and displacement of sedimentary layers was simulated with horizontal flow barriers (HFBs) (Hsieh and Freckleton, 1993) that are specified on the vertical faces of model cells to represent the fault. Decreased conductance between adjacent model cells was specified with a "hydraulic characteristic" that is conceptually equivalent to the hydraulic conductivity of the fault zone (in the direction perpendicular to the fault plane) divided by the width of the fault zone. HFBs were used to simulate the Baton Rouge Fault in all aquifer model layers except the top specified-head layer.

\section{Time Discretization}

An initial steady-state stress period was used to simulate groundwater levels prior to 1940. Seventy-seven annual stress periods allowed specification of the annual groundwater withdrawal data available for the period between January 1, 1940, and December 31, 2016 (table 1). Each annual stress period was discretized with five time steps, such that the first time step represents 33.4 days and subsequent time steps geometrically increase in duration by a factor of 1.4. The three hypothetical scenarios each simulate 96 additional years (2017 through 2112) with two additional stress periods: (1) a 31-year stress period that encompasses January 1, 2017, through December 31, 2047; and (2) a 65-year stress period

Table 1. Summary of groundwater model time discretization.

\begin{tabular}{clccl}
\hline Stress \\
period & $\begin{array}{c}\text { Groundwater } \\
\text { flow model } \\
\text { solution }\end{array}$ & $\begin{array}{c}\text { Years } \\
\text { repre- } \\
\text { sented }\end{array}$ & $\begin{array}{c}\text { Flow time } \\
\text { steps per } \\
\text { stress } \\
\text { period in } \\
\text { groundwater } \\
\text { model }\end{array}$ & $\begin{array}{c}\text { Duration of } \\
\text { first flow } \\
\text { time step }\end{array}$ \\
\hline 1 & Steady state & $1900-39$ & 1 & Not applicable \\
$2-78$ & Transient & $1940-2016$ & 5 & 33.4 days \\
79 & Transient & $2017-47$ & 15 & 29.3 days \\
80 & Transient & $2048-2112$ & 3 & 5,445 days \\
\hline
\end{tabular}

that encompasses January 1, 2048, through December 31, 2112. Withdrawals remain constant between the two additional stress periods of each scenario, which are separated only to facilitate comparison of water levels and concentrations simulated for December 31, 2047, amongst the three scenarios. The geometric progression of increasing time-step length provided good temporal discretization for simulation of transient changes in groundwater levels. In the solutetransport simulations, flow time steps are further subdivided into transport time steps. The number of transport time steps was computed internally on the basis of the flow velocity to maintain numerical stability and varied with the specified effective porosity and boundary conditions, such as specified groundwater-withdrawal rates. Smaller transport time steps are required for faster flow velocities.

\section{Boundary Conditions}

Boundary conditions were specified at the boundaries of the groundwater-flow system and within the model domain where they simulate groundwater-withdrawal wells. Three types of boundary conditions were specified for the groundwater-flow model: no flow, specified head, and headdependent flux. Constant-concentration boundaries were also specified at the lateral boundaries of the solute-transport model.

\section{No-Flow Boundaries}

The north, east, and west sides, and top 27 layers of the southern side of the groundwater-flow model domain (fig. 1) are located where negligible groundwater flow is presumed to enter or exit the model domain and were accordingly considered no-flow boundaries. The model-domain perimeter was located sufficiently far from the Baton Rouge area to minimize any effect on simulated water levels in that area from possible inaccuracy of the no-flow boundary-condition specification. The bottom model boundary at the base of layer 28 is also no flow and corresponds to the top of a confining unit located above the Catahoula Formation (fig. 2) that restricts vertical groundwater flow.

\section{Specified-Head Boundaries}

Water levels in the top model layer (layer 1, which represents the Mississippi River alluvial aquifer, shallow sands, Upland terrace aquifer, and "400-foot" sand) were specified with the Flow and Head Boundary package (Leake and Lilly, 1997). Ten water-level distributions that represent the years 1944, 1970, 1980, 1985, 1990, 1998, 1999, 2000, 2004, and 2015 were constructed from existing data. Water levels for times between these years were linearly interpolated for each model cell in the top layer. Steady-state (predevelopment) water levels were specified at the 1944 levels, and water levels for times after 2015 were specified at the 2015 levels. The accuracy of these water-level specifications was verified 
by calculating the differences between the specified water levels and 1,780 water levels measured in wells screened within the "400-foot" sand, the Mississippi River alluvial aquifer, the shallow sands of the Baton Rouge area, and the Upland terrace aquifer (hereafter referred to as the "upper aquifers"). The mean magnitude of the water-level residuals (measured minus simulated water level) was $9.0 \mathrm{ft}$, and the standard deviation of the residuals was $15.6 \mathrm{ft}$.

Water-level distributions representing the following years were digitized from previous reports: predevelopment (1944) (Kuniansky, 1989), 1980-84 (Martin and Whiteman, 1985; Boswell and Arthur, 1988; Kuniansky, 1989), and 1990 (Tomaszewski, 1996). Historical water-level observations were used to enhance the predevelopment water-level map (Kuniansky, 1989) in some areas. The water-level maps for 2004 and 2015 were created by using water-level data collected by the USGS in cooperation with the Commission and the DOTD. Water-level maps for 1998 and 1999 were created by modification of the 1990 and 2004 water-level maps by using water levels measured in selected wells during 1998 and 1999. Because little water-level change has occurred within the model domain in Mississippi, interpreted water levels in Mississippi during 1982 (Boswell and Arthur, 1988) were incorporated into all of the water-level maps used to specify transient water levels with the Flow and Head Boundary package. Groundwater levels in the southernmost row of the bottom model layer (row 147 in layer 28) were specified to simulate groundwater underflow that exited the model domain toward the south under predevelopment conditions.

\section{Head-Dependent Flux Boundaries}

When a quantity of groundwater is withdrawn from a well that is screened in more than one aquifer interval, the proportion contributed by each interval depends upon the differences in head, aquifer hydraulic conductivity, and aquifer-to-well-screen conductance between the screened aquifer intervals. When large head differences exist between aquifer intervals, substantial intra-borehole flow between the aquifer intervals may occur. MODFLOW simulates these effects with the MNW2 package, which computes a layer-by-layer distribution of withdrawal for each well on the basis of the hydraulic conductivities and simulated water levels in each finite-difference cell connected to the simulated well-screen interval. Because withdrawal wells screened within the "1,500-foot" sand span multiple model layers and many wells are screened within more than one aquifer, the average daily groundwater withdrawals from each well were initially specified with the MNW2 package in the MODFLOW model. When withdrawals were not specified from a previously installed and unplugged well, flow between model layers through the connecting wellbore was simulated where differences in simulated water levels existed between model layers.
Groundwater withdrawals from wells screened in the top model layer (layer 1) corresponding to the Mississippi River alluvial aquifer, shallow sands, Upland terrace aquifer, and "400-foot" sand were not simulated, because water levels in this layer were a specified boundary condition.

\section{Specified-Concentration Boundaries and Initial Conditions}

Although the locations of saltwater sources in the Baton Rouge sands are uncertain, they were conceptualized as originating near and south of the Baton Rouge Fault and are simulated with constant-concentration boundaries in the model layers that represent the "1,500-foot" sand, "2,400-foot" sand, and "2,800-foot" sand. Initial chloride concentrations were set to zero (corresponding to freshwater) in all areas north of the Baton Rouge Fault within the "1,500-foot" and "2,400-foot" sands. The distribution of initial concentrations in the " 2,800 -foot" sand north of the Baton Rouge Fault is described below. Initial concentrations in model layers representing other hydrogeologic units were set to zero, because simulation of saltwater transport in those units is not within the scope of this study.

The source of saltwater at the base of the " 1,500 -foot" sand was simulated on the south side of the Baton Rouge Fault for a 3.6-mi-long region extending east from the Mississippi River as a constant concentration of $11,000 \mathrm{mg} / \mathrm{L}$ of chloride in model layer 20 in the two rows south of the Baton Rouge Fault within columns 16 through 53 (inclusive).

In the "2,400-foot" sand, the saltwater source was simulated as a constant-concentration boundary of 2,200 $\mathrm{mg} / \mathrm{L}$ three model rows south of the simulated location of the Baton Rouge Fault in model-grid layer 26, columns 14 through 122, corresponding to a 10-mi-long region extending from $0.5 \mathrm{mi}$ west of the Mississippi River to $9.5 \mathrm{mi}$ east of the Mississippi River. The location and concentration of this boundary were determined by trial and error calibration of simulated to measured chloride concentrations in wells north of the fault. Representation of the saltwater source $1,500 \mathrm{ft}$ south of the fault enabled accurate simulation of the arrival time of saltwater in observation wells north of the fault, suggesting the saltwater is transported some distance prior to crossing the fault.

In contrast to overlying aquifers in the Baton Rouge area, saltwater was present north of the Baton Rouge Fault in the "2,800-foot" sand before groundwater development. In order to represent a plausible distribution of that saltwater, constant chloride concentrations of 2,000-mg/L were defined for areas south of model row 97, which corresponds to the location 2.0 mi north of the of Baton Rouge Fault at the Mississippi River. North of row 97, the initial concentrations within variable-concentration cells were specified to decrease northward from 2,000 to $40 \mathrm{mg} / \mathrm{L}$ over $1.9 \mathrm{mi}$. 


\section{Hydraulic Property Distributions}

The horizontal hydraulic conductivity $\left(\mathrm{K}_{\mathrm{h}}\right)$ for aquifer model layers representing the "600-foot" sand (layer 3), "800-foot" sand (layer 5), "1,000-foot" sand (layer 7), "1,200-foot" sand (layer 9), "1,700-foot" sand (layer 22), and "2,000-foot" sand (layer 24) were each represented by single parameters estimated during model calibration. The simulated transmissivity of these aquifers varies spatially with their specified variable thickness. Because the water levels in the top model layer are simulated with a specified-head boundary condition, they are independent of hydraulic conductivity and arbitrarily set equal to that of the underlying "600-foot" sand, which was estimated during model calibration.

Heterogeneity of $\mathrm{K}_{\mathrm{h}}$ within the "1,500-foot" sand, "2,400-foot" sand, and "2,800-foot" sand was simulated by interpolation between values estimated at "pilot points" co-located with selected observation wells in each aquifer. The parameterized $\mathrm{K}_{\mathrm{h}}$ at 19 loci within the "1,500-foot" sand, 20 loci within the "2,400-foot" sand, and 20 loci within the "2,800-foot" sand were estimated during model calibration. The $\mathrm{K}_{\mathrm{h}}$ between the pilot-point locations in each of these aquifers was specified by ordinary kriging with an isotropic spherical variogram. To avoid "over fitting" observed water levels, the $\mathrm{K}_{\mathrm{h}}$ parameter distributions were smoothed with "Tikhonov Regularization" (Doherty, 2016) to constrain differences in parameter values between neighboring pilot points.

Distinct simulated vertical hydraulic conductivities $\left(\mathrm{K}_{\mathrm{v}}\right)$ of model layers that represent confining units (model layers $2,4,6,8,10,21,23,25$, and 27 ; subsequently referred to as "confining-unit layers") are homogeneous within each confining unit. The $\mathrm{K}_{\mathrm{v}}$ of all aquifers was insensitive and represented with a single parameter value for all aquifer model layers. Similarly, the $\mathrm{K}_{\mathrm{h}}$ of all confining units was specified with a single parameter (table 2). Separate parameters that represent specific storage $\left(\mathrm{S}_{\mathrm{s}}\right)$ within each aquifer and confining-unit layer were estimated during model calibration (except for the top specified-head model layer).

Two distinct "hydraulic characteristics" were estimated for HFBs representing the Baton Rouge Fault for both model layers representing the "1,500-foot" sand (layers 11-20) and the model layer representing the "2,400-foot" sand (layer 26). A single "hydraulic characteristic" was estimated for HFBs representing the Baton Rouge Fault in each of the other aquifer model layers (layers 3, 5, 7, 9, 22, 24, and 28). The calibrated values of the hydraulic properties for the groundwater-flow model are summarized in table 2.

Homogeneous distributions of aquifer longitudinal, transverse, and vertical dispersivity, molecular diffusion, and effective porosity were specified within each aquifer for solving the advection-dispersion equation with SEAWAT. The calibrated values of these parameters are summarized in the "Estimated Parameter Values" section of this report and in table 2.

\section{Model Calibration}

The groundwater-flow model was calibrated to obtain the best overall agreement between measured water levels and their corresponding values simulated with MODFLOW. The specification of groundwater withdrawals from wells constrained the flux of groundwater through the aquifer system and the hydraulic conductivities. The suite of parameters that represent a specified boundary head, the horizontal and vertical hydraulic conductivities of aquifers and confining units, the specific storage of aquifers and confining units, and fault hydraulic characteristics, are summarized in table 2 . The values of these 108 parameters were adjusted to minimize differences between observed and simulated water levels by using the parameter-estimation code PEST++ (Welter and others, 2012).

\section{Calibration Dataset}

The model calibration dataset consisted of historical measurements of groundwater levels, wellbore flow in a "connector well," and chloride concentrations. PEST++ was used to calibrate the water levels simulated with the constant-density MODFLOW model to historical water-level measurements. Chloride concentration data were used for trial and error calibration of additional initial parameters required to simulate solute transport in the variable-density SEAWAT model, including specified concentrations and effective porosity and dispersivity within the "1,500-foot" sand, "2,400-foot" sand, and "2,800-foot" sand.

\section{Water-Level Observations}

A total of 8,810 water-level observations made during the period from 1916 through 2016 from 1,996 wells in Louisiana were selected to calibrate the groundwater-flow model. Waterlevel observations were downloaded from the USGS National Water Information System web interface (U.S. Geological Survey, 2017). Observations known to be influenced by recent nearby pumping in the same aquifer were excluded. Some older observations for which only the year of measurement is known were assigned to July 1st of that year. Records from the many wells that contained more than one measurement per year were winnowed to retain, at most, one water level per year from each well. A representative annual water level was chosen by selecting the water-level measurement with the minimum deviation from the annual mean of measured water levels.

Combined uncertainties associated with wellhead altitude and depth-to-water measurements in the study area were previously estimated to be about $2.5 \mathrm{ft}$ (Heywood and others, 2014). Because wellhead altitude and depth-towater measurement errors were similar for all water-level measurements, equal regression weights were assigned to water-level measurements in aquifers beneath the " 400 -foot" sand (model layer 1) in PEST ++ . Water-level measurements from the "400-foot" sand have zero weight, because water 
18 Simulation of groundwater flow and chloride transport in the "1,500-foot," "2,400-foot," and "2,800-foot" sands

Table 2. Parameter values and sensitivities for the calibrated groundwater-flow model.

[ft, foot; $\mathrm{ft} / \mathrm{d}$, foot per day; $\mathrm{ft}^{2} / \mathrm{d}$, foot squared per day; numbers in parameter names correspond to aquifer name (see fig. 2); \%, percent; n/a, not applicable]

\begin{tabular}{|c|c|c|c|c|}
\hline Parameter type & Units & Parameter name & Calibrated value & Composite sensitivity \\
\hline Specified head & $\mathrm{ft}$ & bound_head & 70 & 6.7 \\
\hline \multirow{8}{*}{ Horizontal hydraulic conductivity } & \multirow{8}{*}{$\mathrm{ft} / \mathrm{d}$} & k_400-600sand & 42.2 & 2.4 \\
\hline & & k_1000sand & 68.8 & 1.9 \\
\hline & & k_1200sand & 53.6 & 7.0 \\
\hline & & k_1700sand & 54.3 & 4.6 \\
\hline & & k_2000sand & 64.0 & 15 \\
\hline & & $\mathrm{k} \_2400$ sand $^{2}$ & $11.4-200$ & Various \\
\hline & & k_2800sand ${ }^{3}$ & $19.9-210$ & Various \\
\hline & & k_confining_unit & 0.01 & 0.24 \\
\hline \multirow{7}{*}{ Vertical hydraulic conductivity } & \multirow{7}{*}{$\mathrm{ft} / \mathrm{d}$} & vk_8con10 & $4.6 \times 10^{-4}$ & 3.3 \\
\hline & & vk_10con 12 & $4.6 \times 10^{-4}$ & 3.7 \\
\hline & & vk_12con 15 & $5.9 \times 10^{-4}$ & 3.1 \\
\hline & & vk_15con 17 & $3.1 \times 10^{-4}$ & 3.1 \\
\hline & & vk_17con20 & $5.8 \times 10^{-4}$ & 4.4 \\
\hline & & vk_20con24 & $2.3 \times 10^{-4}$ & 5.3 \\
\hline & & vk_24con 28 & $4.5 \times 10^{-4}$ & 5.9 \\
\hline \multirow{12}{*}{ Specific storage } & \multirow{12}{*}{$\mathrm{ft}^{-1}$} & ss_400-600sand & $3.0 \times 10^{-6}$ & 0.16 \\
\hline & & ss_2400sand & $1.2 \times 10^{-6}$ & 0.39 \\
\hline & & ss_2800sand & $1.0 \times 10^{-6}$ & 0.56 \\
\hline & & ss_4con6 & $3.7 \times 10^{-6}$ & 0.05 \\
\hline & & ss_6con 8 & $2.0 \times 10^{-6}$ & 0.12 \\
\hline & & ss_8con 10 & $3.2 \times 10^{-6}$ & 0.10 \\
\hline & & ss_10con 12 & $2.9 \times 10^{-6}$ & 1.9 \\
\hline & & ss_12con 15 & $1.6 \times 10^{-6}$ & 0.31 \\
\hline & & ss_15con 17 & $7.6 \times 10^{-6}$ & 2.2 \\
\hline & & ss_ 17 con 20 & $1.0 \times 10^{-5}$ & 3.7 \\
\hline & & ss_20con24 & $1.0 \times 10^{-6}$ & 0.62 \\
\hline & & ss_24con 28 & $8.8 \times 10^{-6}$ & 4.5 \\
\hline
\end{tabular}


Table 2. Parameter values and sensitivities for the calibrated groundwater-flow model.-Continued

[ft, foot; $\mathrm{ft} / \mathrm{d}$, foot per day; $\mathrm{ft}^{2} / \mathrm{d}$, foot squared per day; numbers in parameter names correspond to aquifer name (see fig. 2); \%, percent; n/a, not applicable]

\begin{tabular}{|c|c|c|c|c|}
\hline Parameter type & Units & Parameter name & Calibrated value & Composite sensitivity \\
\hline \multirow{8}{*}{ Fault hydraulic characteristic } & \multirow{8}{*}{ day $^{-1}$} & hfb_600ft & $3.3 \times 10^{-5}$ & 0.05 \\
\hline & & hfb_800ft & $1.1 \times 10^{-4}$ & 0.08 \\
\hline & & hfb_1200ft & $2.0 \times 10^{-4}$ & 1.0 \\
\hline & & hfb_1500ft & $1.4 \times 10^{-4}$ & 1.3 \\
\hline & & hfb_2000ft & $1.0 \times 10^{-5}$ & 0.40 \\
\hline & & hfb_2400ft & $6.4 \times 10^{-5}$ & 1.4 \\
\hline & & hfb_2400ft_east & $3.0 \times 10^{-4}$ & 1.1 \\
\hline & & hfb_2800ft & $2.8 \times 10^{-4}$ & 2.8 \\
\hline Longitudinal dispersivity & $\mathrm{ft}$ & & $50-250$ & $\mathrm{n} / \mathrm{a}$ \\
\hline Horizontal transverse dispersivity & $\mathrm{ft}$ & & $5-25$ & $\mathrm{n} / \mathrm{a}$ \\
\hline Vertical transverse dispersivity & $\mathrm{ft}$ & & $0.05-0.25$ & $\mathrm{n} / \mathrm{a}$ \\
\hline Molecular diffusion & $\mathrm{ft}^{2} / \mathrm{d}$ & & $1 \times 10^{-3}$ & $\mathrm{n} / \mathrm{a}$ \\
\hline
\end{tabular}

${ }^{1}$ Nineteen parameters represented horizontal hydraulic conductivity at pilot points in the $1,500-\mathrm{ft}$ sand.

${ }^{2}$ Twenty parameters represented horizontal hydraulic conductivity at pilot points in the 2,400 - $\mathrm{ft}$ sand.

${ }^{3}$ Twenty parameters represented horizontal hydraulic conductivity at pilot points in the 2,800 - $\mathrm{ft}$ sand.

levels were specified for layer 1. Although removed from the parameter-estimation regression by assignment of zero weight, these observations were retained in the model for comparison to the specified water levels.

Water-level observation wells were assumed to be tightly cased so that water-level measurements represent the altitude of the potentiometric surface at reported screen altitudes. Some (162) anomalous water-level measurements were removed from calibration by assignment of zero weight, because they were considered unlikely to be accurate indicators of aquifer water levels. Possible reasons for erroneous water-level measurements include (1) well leakage from an aquifer above the well screen interval, and (2) measurement immediately after pumping and before the well has equilibrated with ambient aquifer water levels. About 80 percent $(7,030)$ of the measurements, which were made in wells screened in aquifers deeper than the " 400 -foot" sand, were used to estimate parameters in the groundwater-flow model calibration. The remaining 20 percent $(1,780)$ were from wells screened in the " 400 -foot" sand and were used to evaluate the accuracy of the transient water levels specified for the top model layer. Altitudes of water levels in the calibration dataset are between 353 and $-292 \mathrm{ft}$, a range of $645 \mathrm{ft}$.

The water-level dataset included 939 measurements from 196 wells screened within the "1,500-foot" sand (or the stratigraphically correlative aquifers in the eastern Florida Parishes that are simulated by layers 11-20, fig. 2). Hydrographs (fig. 9) from wells in East Baton Rouge Parish (fig. 10) illustrate the water-level declines that have occurred within the "1,500-foot" sand since 1942. A 183-ft water-level decline was measured between the years 1943 and 2009 in well EB-168 (fig. 9), located near Interstate 110 east of the industrial district. An 82-ft water-level decline was measured between 1966 and 1992 in well EB-807A, which is located about $0.8 \mathrm{mi}$ southwest of public-supply groundwater withdrawals from the "1,500-foot" sand (fig. 9). An anomalous 20 -ft water-level recovery was measured in well EB-792A between 1970 and 1974. An 88-ft water-level decline was measured between 1965 and 2005 in well EB-783A, which is located south of the Baton Rouge Fault and about 1 mi east of the "1,500-foot" sand withdrawals depicted west of the Mississippi River in figure 6. 
EB-168

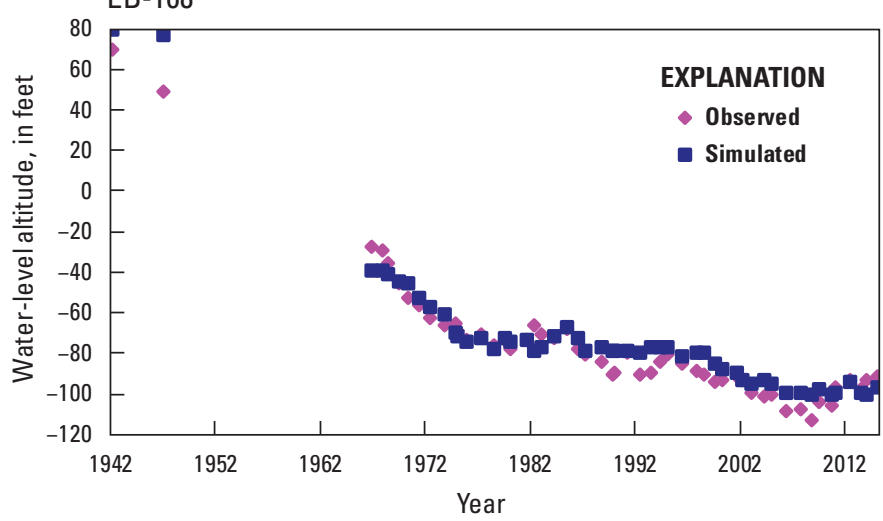

EB-917

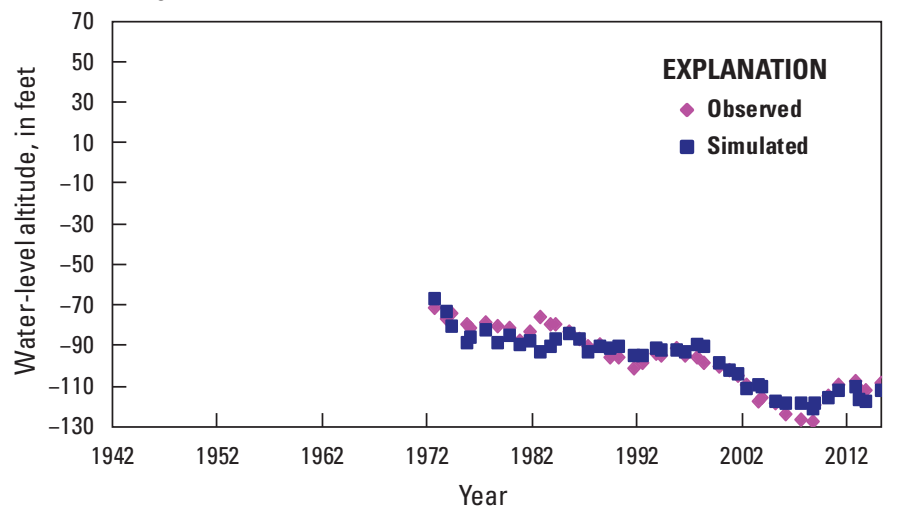

EB-782B

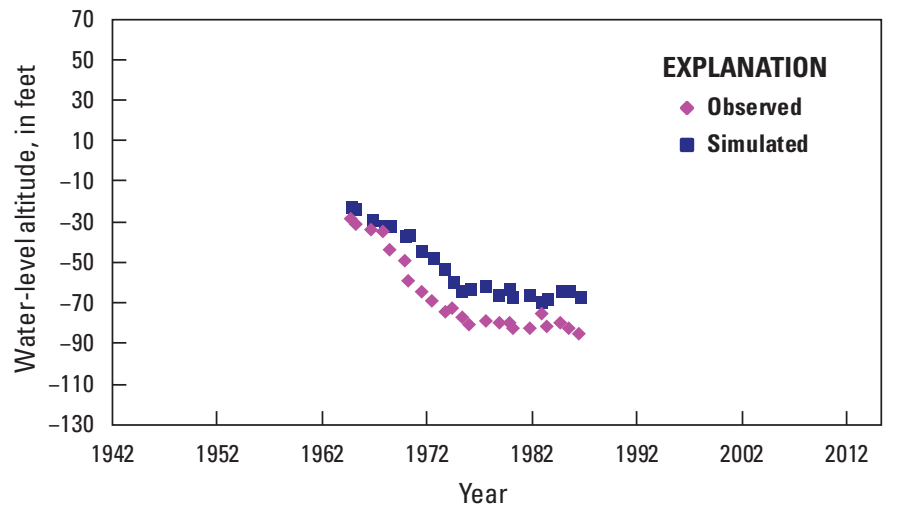

EB-783A

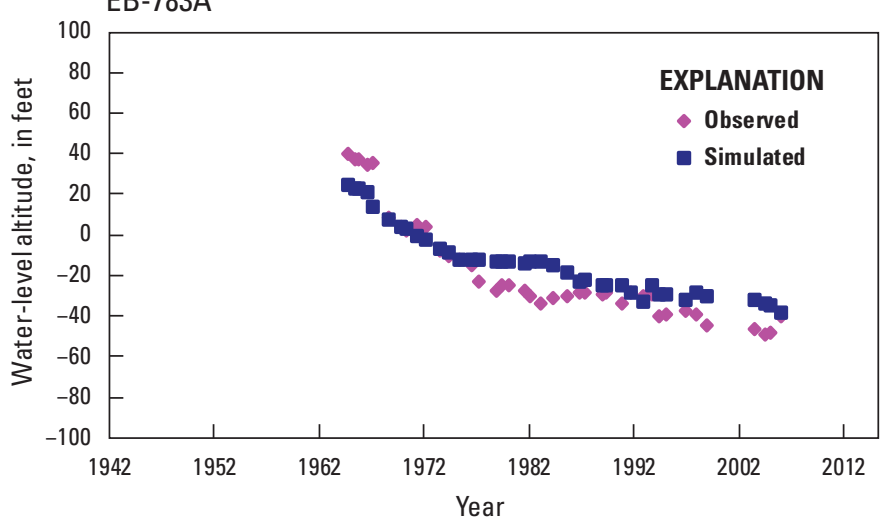

EB-807A

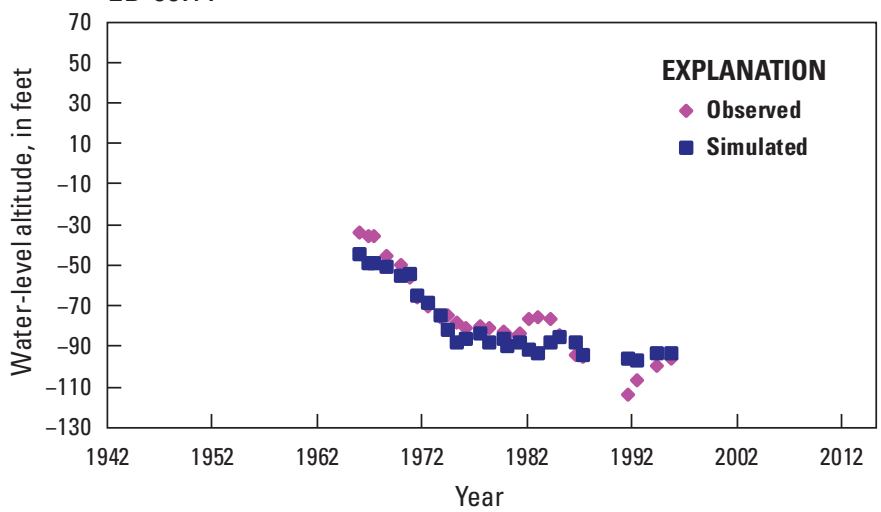

EB-918

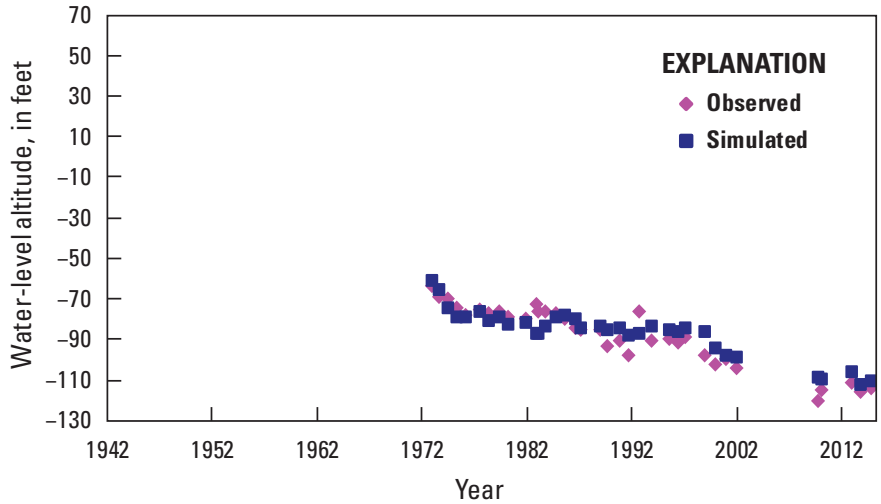

EB-792A

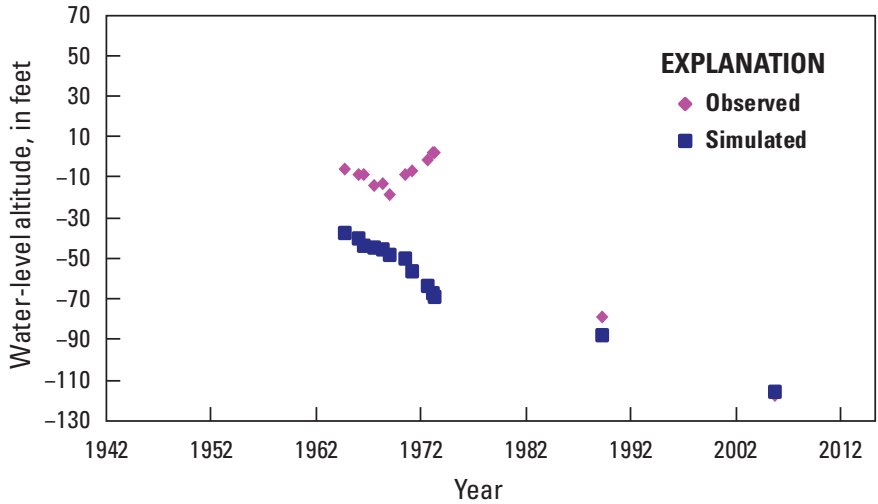

$\mathrm{EB}-789 \mathrm{~B}$

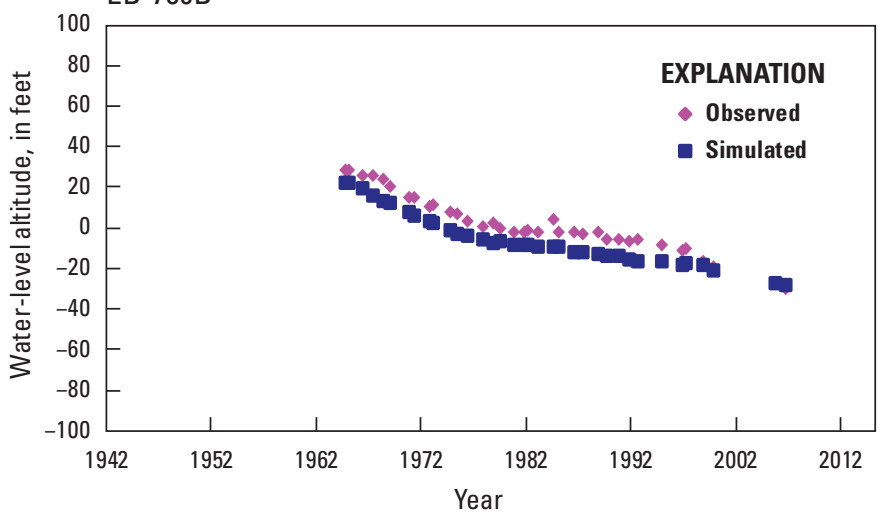

Figure 9. Measured and simulated water levels within the "1,500-foot" sand of the Baton Rouge area in southeastern Louisiana. 


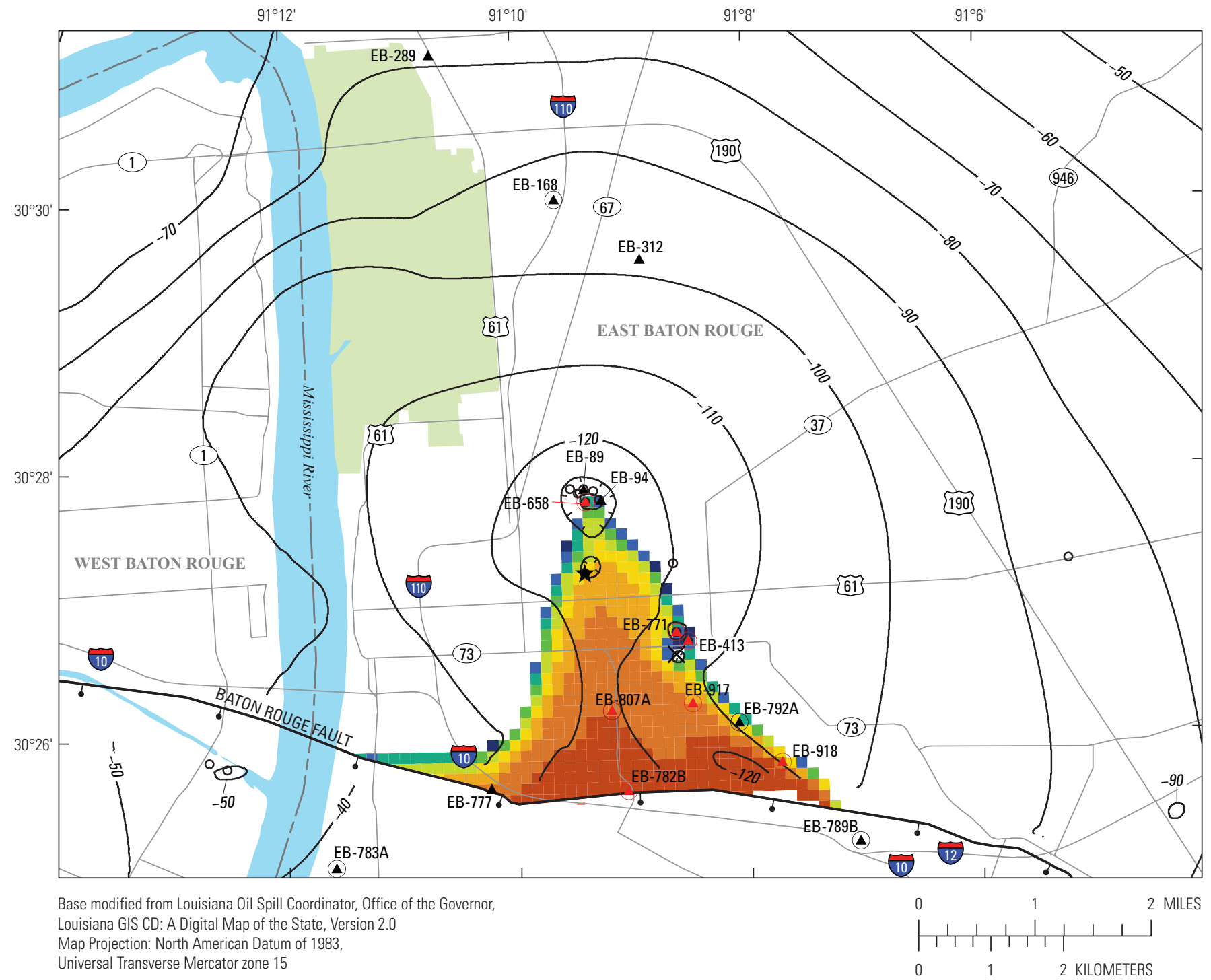

EXPLANATION

\section{Industrial district}

Simulated chloride concentration in milligrams per liter

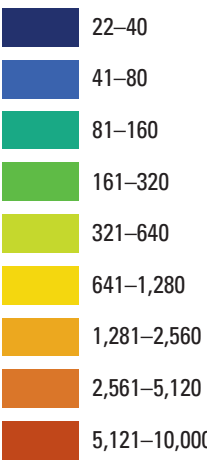

- -70- Simulated water-level contour-Shows altitude at which water would stand in tightly cased wells. Contour interval is 10 feet. Datum is National Geodetic Vertical Datum of 1929

- Normal fault-Bar and ball on

$\times \quad$ Connector Well

$\star \quad$ Scavenger Well

Ab-777 Observation well and well number

Well for which chlorograph is EB-917 shown and well number

(4) Well for which hydrograph is EB-792 shown and well number

- Water well screened in the "1,500-foot" sand with pumping simulated in the mode

Universal Transverse Mercator zone 15

Figure 10. Simulated 2016 water levels and chloride concentrations in the "1,500-foot" sand of the Baton Rouge area in the detailed model area in southeastern Louisiana. 
The water-level dataset included 804 measurements from 165 wells screened within the "2,400-foot" sand (or stratigraphically correlative aquifers in the eastern Florida Parishes that are simulated by layer 26, fig. 2). Hydrographs shown in figure 11 illustrate the magnitude of measured water-level declines since 1941 in West Feliciana (WF-286), Pointe Coupee (PC-70), Livingston (Li-85), and West Baton Rouge (WBR-100B) Parishes (fig. 12). Although measured water levels in the "2,400-foot" sand declined throughout most of the study area, the largest water-level declines have been observed in East Baton Rouge Parish, where large groundwater withdrawals occur (fig. 7). Water levels in East Baton Rouge Parish generally declined during the 1960s and 1970s, recovered somewhat during the early 1980s, then continued to decline in most wells until the present (2016). About 6 mi northeast of the industrial district, a 165-ft decline was measured in well EB-322 from 1942 through 2012 (fig. 11). About $1,000 \mathrm{ft}$ north of the Baton Rouge Fault, a 102-ft water-level decline in well EB-794 between 1965 and 2006 was followed by a 27-ft water-level rise from 2006 to 2011.

The water-level dataset included 934 measurements from 176 wells screened within the " 2,800 -foot" sand (or stratigraphically correlative aquifers in the eastern Florida Parishes that are represented by model layer 28, fig. 2). Hydrographs shown in figure 13 illustrate the magnitude of measured water-level declines since 1946 in East Feliciana (EF-2, EF-223), Pointe Coupee (PC-81), and East Baton Rouge (EB-468, EB-578B, EB-581, EB-517C, EB-944) Parishes. Water levels in well EB-468, located near where groundwater withdrawals occur (fig. 14), decreased $150 \mathrm{ft}$ between the years 1948 and 2011 (fig. 13).

Well location and construction information from USGS, DOTD, and DNR records was used to specify the screen intervals and locations of the observation wells. Most $(8,065)$ of the water-levels used for calibration were measured in wells with screen intervals corresponding to a single model layer, but 745 were measured in wells with either long or multiple screens that correspond to more than one model layer. In the latter cases, the water levels measure a composite of heads in the screened aquifer-depth intervals. The majority of these multilayer observations were measured in wells screened in the " 1,500 -foot" sand, which is represented by 10 model layers with identical $\mathrm{K}_{\mathrm{h}}$ distributions. MODFLOW simulates a composite water level corresponding to each multilayer observation well by averaging the water levels simulated in the model cells specified for the well screen.

\section{Wellbore-Flow Observation}

A flow rate of about 475 gallons per minute ( $\mathrm{gal} / \mathrm{min}$ ) from the "800-foot" sand to the "1,500-foot" sand was measured during December 1998 (Dial and Cardwell, 1999) in well EB-1293, which is a "connector well" screened in the "800-foot" and "1,500-foot" sands. The well was installed to transmit fresh groundwater from the " 800 -foot" sand to the "1,500-foot" sand in an attempt to raise the water level in the "1,500-foot" sand and reduce saltwater encroachment toward public-supply wells located just north of EB-1293. The simulated borehole flow rate was calibrated to the measured flow by adjusting the conductance between the well and the "800-foot" sand. Because additional well development was conducted after this flow measurement and before the well was placed in service on April 6, 1999, it is possible that flow through the "connector well" has been greater than that observed during the initial measurement.

\section{Chloride-Concentration Observations}

A total of 1,673 chloride measurements from 1939 to 2016 compiled from the National Water Information System (U.S. Geological Survey, 2017) constrain the simulated extent and concentration of saltwater within "1,500-foot" sand, "2,400-foot" sand, and "2,800-foot" sand. Within the "1,500-foot" sand, increased concentrations since 1964 in seven wells were used as calibration targets for the simulation of saltwater transport north from the Baton Rouge Fault (fig. 15). Chloride concentrations within the "1,500-foot" sand are vertically stratified, with higher concentrations associated with denser, saltier groundwater measured near the base of the aquifer. Because well EB-782B, located about $500 \mathrm{ft}$ north of the Baton Rouge Fault (fig. 10), has a 5-ft-long screen about $50 \mathrm{ft}$ above the base of the "1,500-foot" sand, chloride concentrations at the base of the "1,500-foot" sand were likely greater than those measured in this well. Well 807A, located about $0.8 \mathrm{mi}$ north of the fault, has a similar screen about $60 \mathrm{ft}$ above the base of the "1,500-foot" sand but relatively higher concentrations measured after 1979. Wells with relatively lower concentrations to the east (EB-771 and EB-413) and north (EB-658) constrain the extent of the highest concentration areas of brackish groundwater.

Chloride concentrations in two wells (EB-794 and EB-804B) screened in the "2,400-foot" sand, each located about 0.2 mi north of the Baton Rouge Fault (fig. 12), increased after 1995 (fig. 16). Concentrations measured in these wells serve as useful calibration targets for simulation of saltwater transport north of the fault. Because measured concentrations in wells farther north (EB-806B and EB-1149) have not risen substantially above background levels, the locations of those wells constrain the extent of saltwater encroachment in the "2,400-foot" sand.

Chloride concentrations measured from 1962 through 1972 increased relatively uniformly to almost $500 \mathrm{mg} / \mathrm{L}$ in wells EB-548, EB-534 and EB-560, which are screened in the "2,800-foot" sand in the industrial district and horizontally separated by less than 1,400 ft (figs. 14 and 17). Groundwater withdrawals from each of these wells were about $800 \mathrm{gal} / \mathrm{min}$ during this period. Measured concentrations in well EB-750, located about $2 \mathrm{mi}$ north of the industrial district, had risen gradually to about $78 \mathrm{mg} / \mathrm{L}$ as of 2015 . By contrast, measured concentrations in well EB-798, located 1.3 mi east of well EB-750, have risen more sporadically and reached $514 \mathrm{mg} / \mathrm{L}$ during the same time period. 

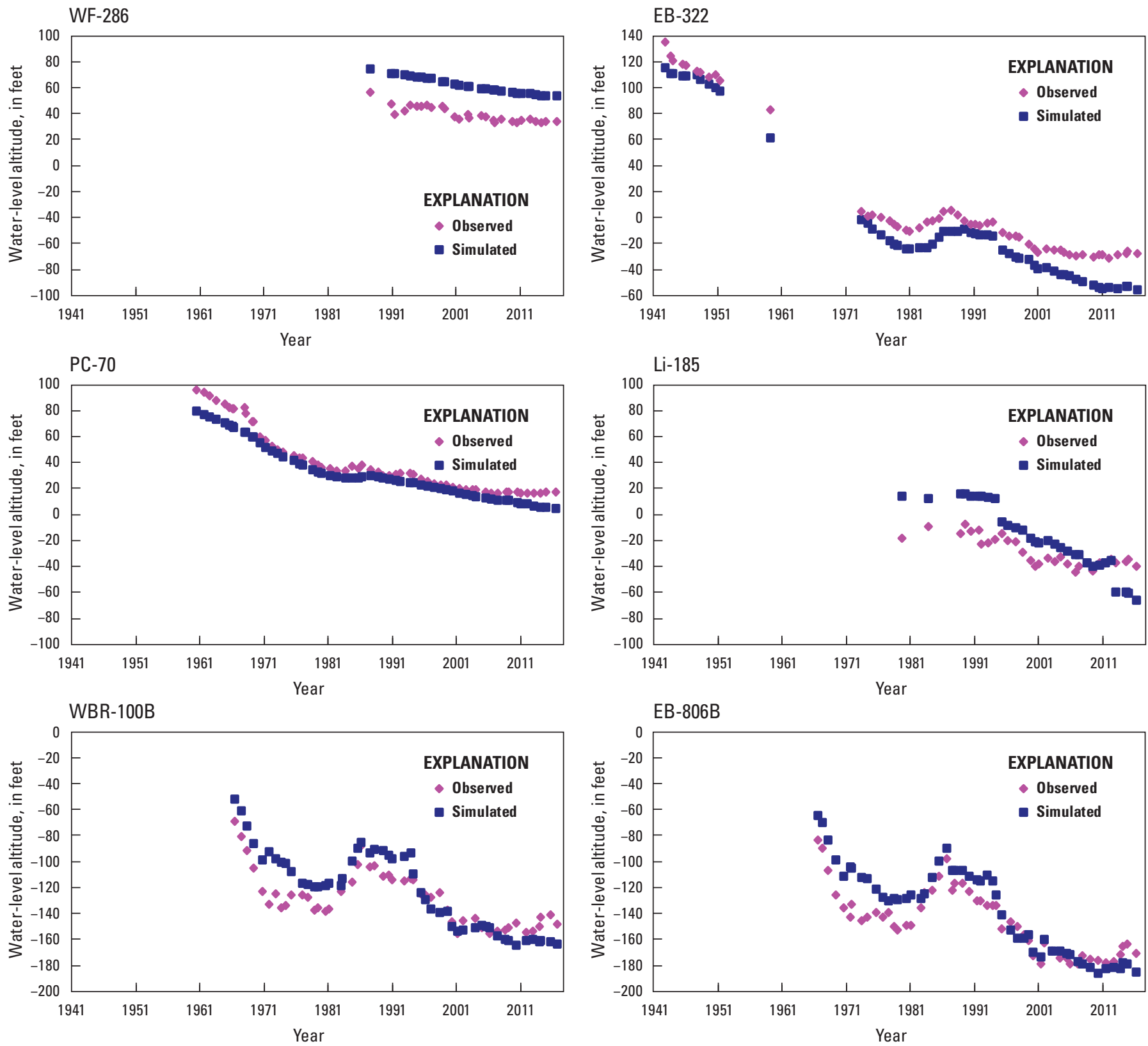

EB-794
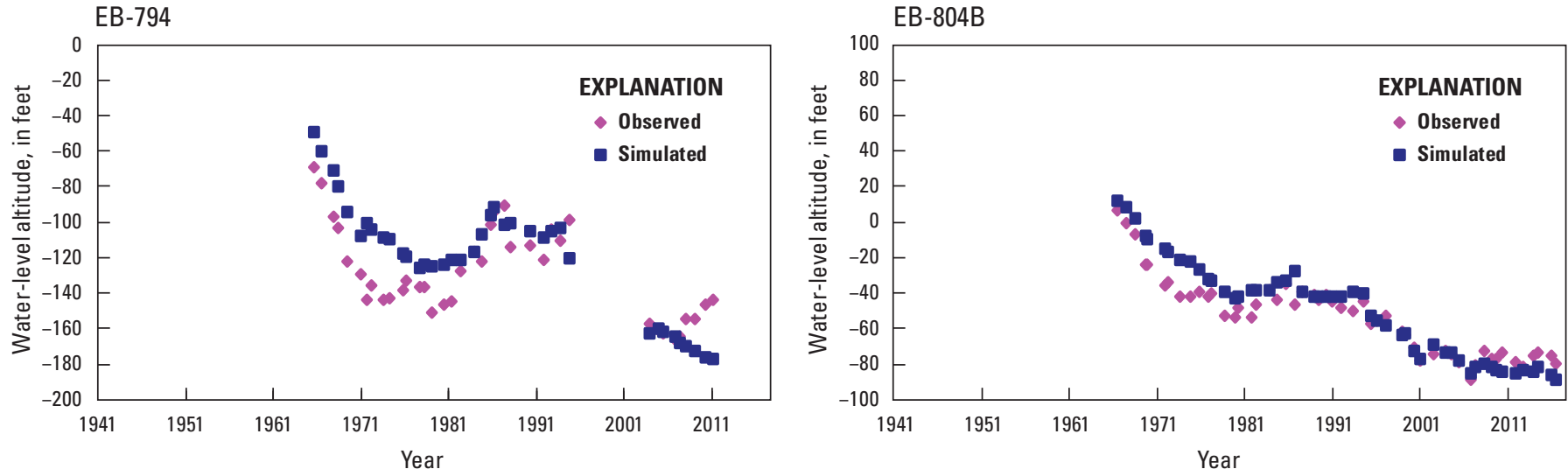

Figure 11. Measured and simulated water levels within the "2,400-foot" sand of the Baton Rouge area in southeastern Louisiana. 


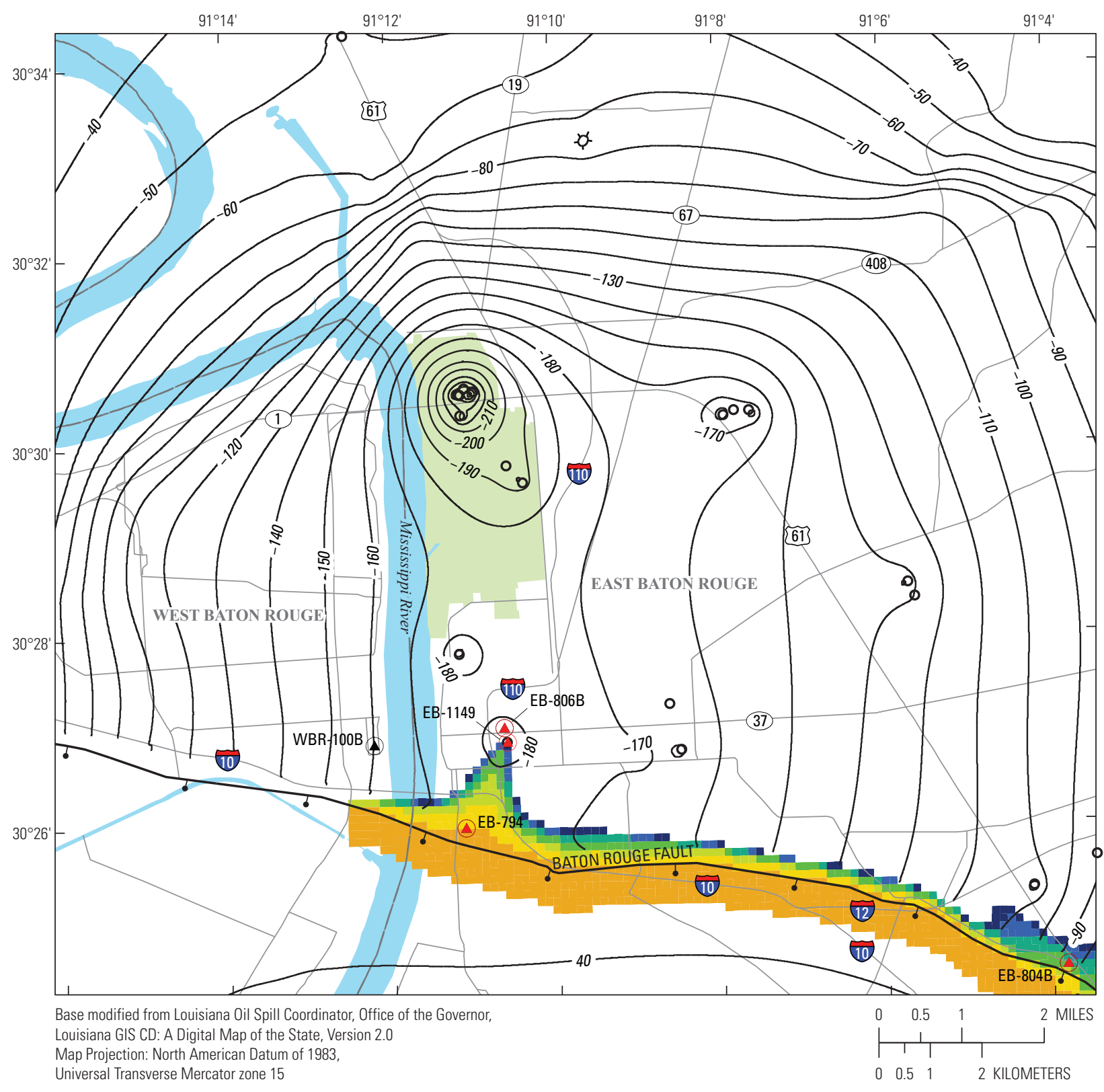

\section{EXPLANATION}

Industrial district

Simulated chloride concentration in milligrams per liter

$22-40$

$41-80$

81-160

$161-320$

321-640

$641-1,280$

$1,281-2,560$

$2,561-5,120$

$5,121-10,000$

- -40 - Simulated water-level contour-Shows altitude at which water would stand in tightly cased wells.

Contour interval is 10 feet. Datum

is National Geodetic Vertical

Datum of 1929

T Normal fault-Bar and ball on downthrown block

EB-794 Observation well and well number

(4) Well for which chlorograph is shown and well number

(4) Well for which hydrograph is

shown and well number

- Water well screened in the "2,400-foot" sand with pumping simulated in the model

Figure 12. Simulated 2016 water levels and chloride concentrations in the "2,400-foot" sand of the Baton Rouge area in the detailed model area in southeastern Louisiana. 

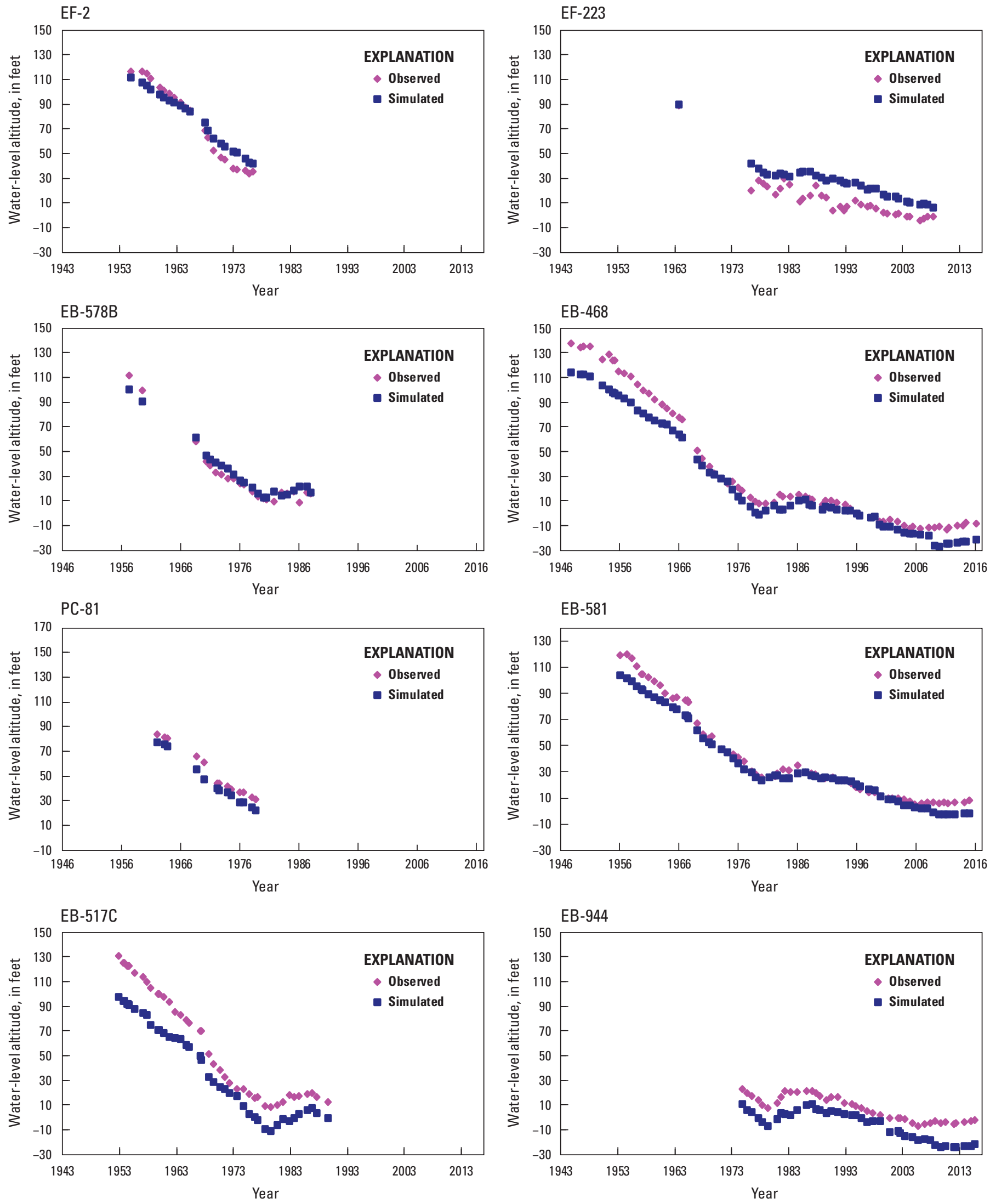

Figure 13. Measured and simulated water levels within the "2,800-foot" sand of the Baton Rouge area in southeastern Louisiana. 


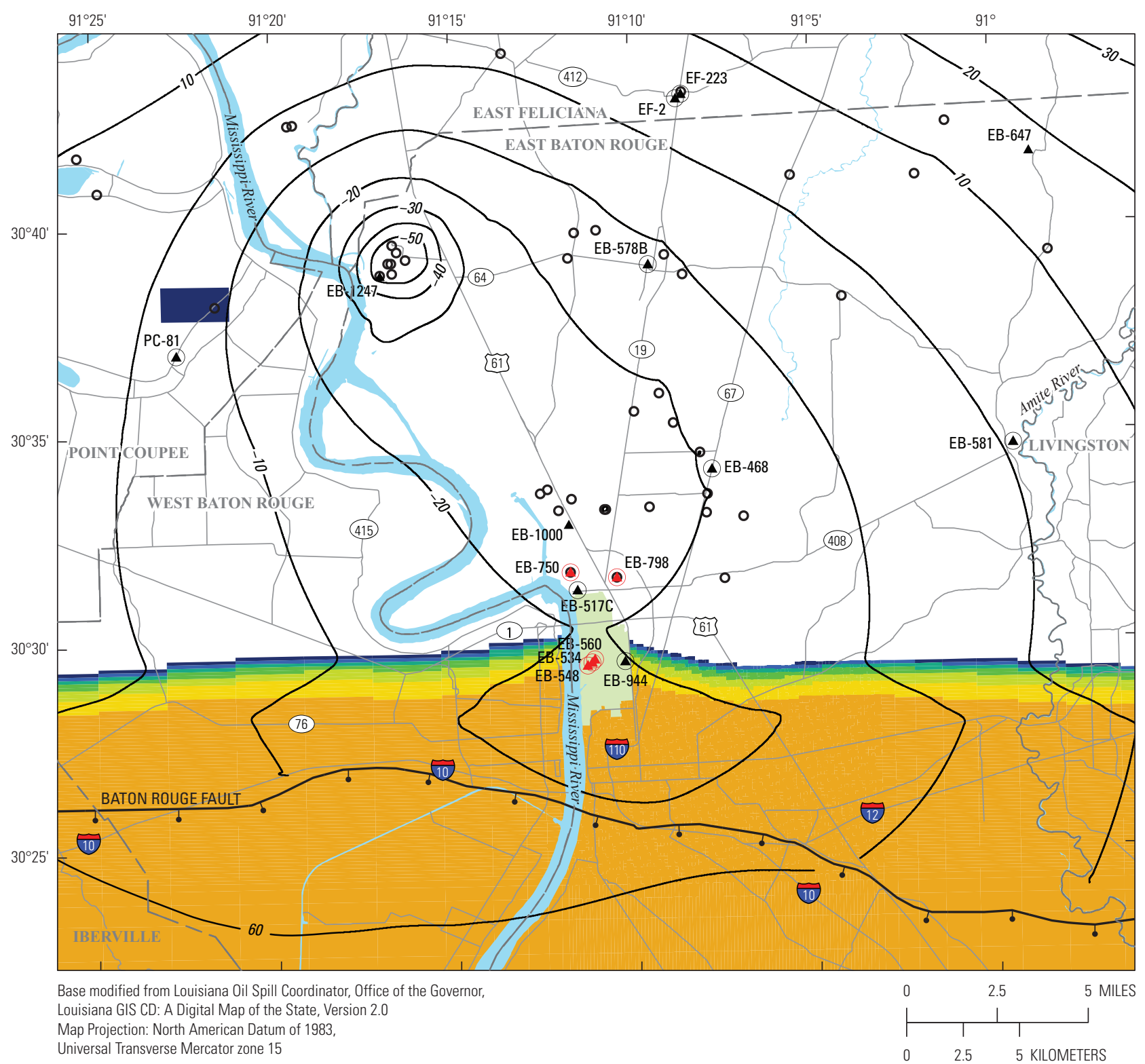

EXPLANATION

Industrial district

Simulated chloride concentration

in milligrams per liter

22-40

$41-80$

81-160

$161-320$

$321-640$

$641-1,280$

$1,281-2,560$

$2,561-5,120$

$5,121-10,000$

-10- Simulated water-level contour-Shows altitude at which water would contor interval is 10 feet. is National Geodetic Vertical Datum of 1929

Tormal fault-Bar and ball on downthrown block

$\Delta$ Observation well and well number

(4) Well for which chlorograph is shown and well number

Well for which hydrograph is shown and well number

- Water well screened in the "2,800-foot" sand with pumping simulated in the model

Figure 14. Simulated 2016 water levels and chloride concentrations in the "2,800-foot" sand of the Baton Rouge area in the detailed model area in southeastern Louisiana. 

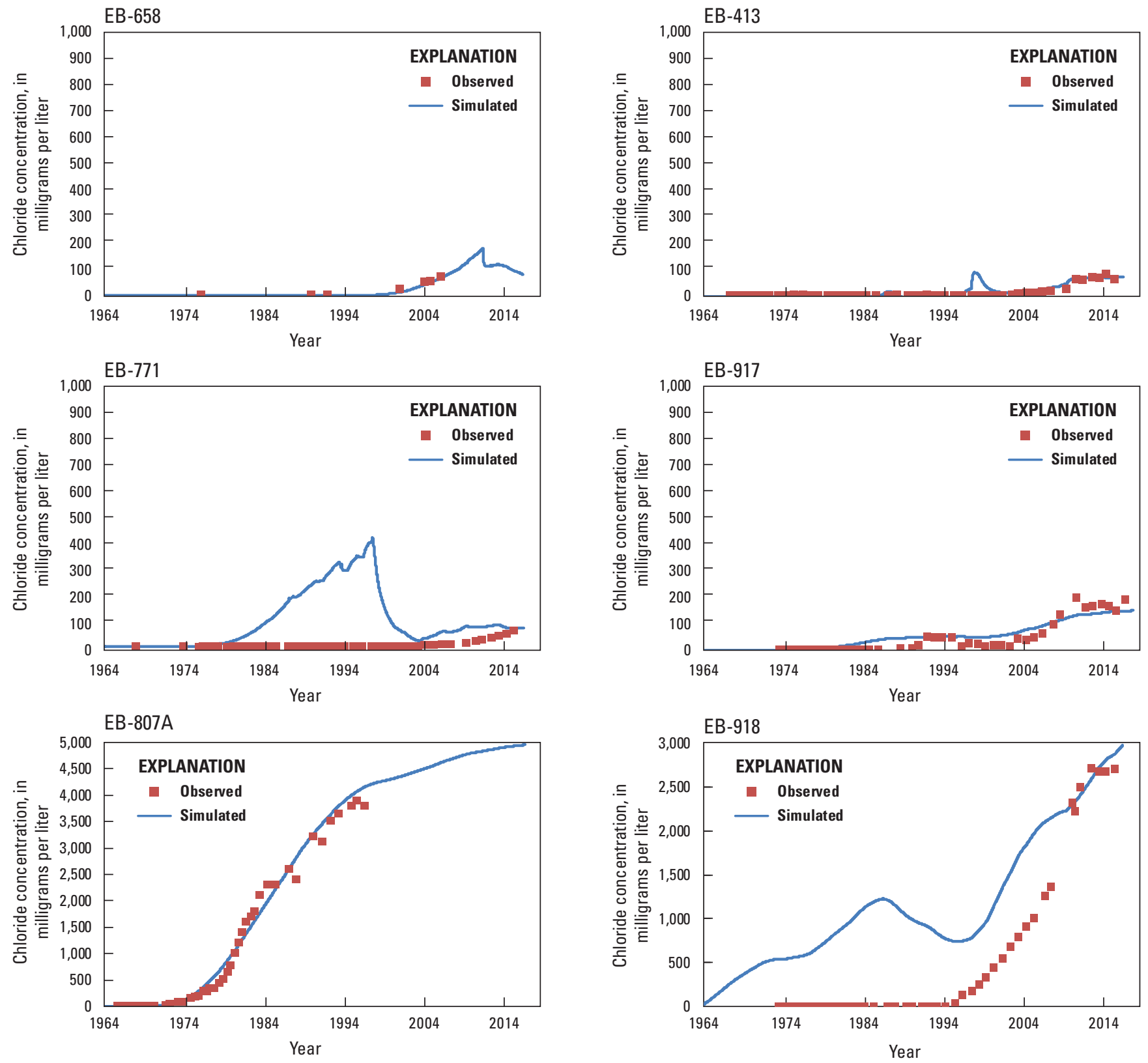

EB-782B

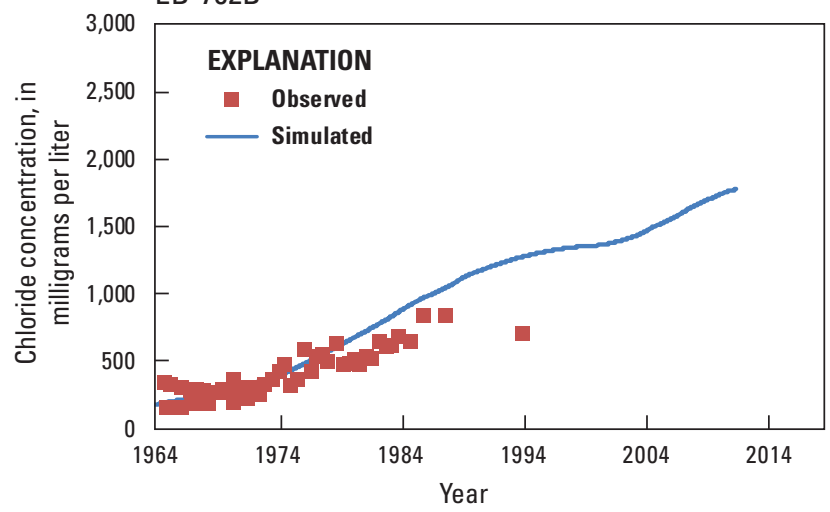

Figure 15. Simulated and observed chloride concentrations at observation wells within the "1,500-foot" sand of the Baton Rouge area in southeastern Louisiana. 

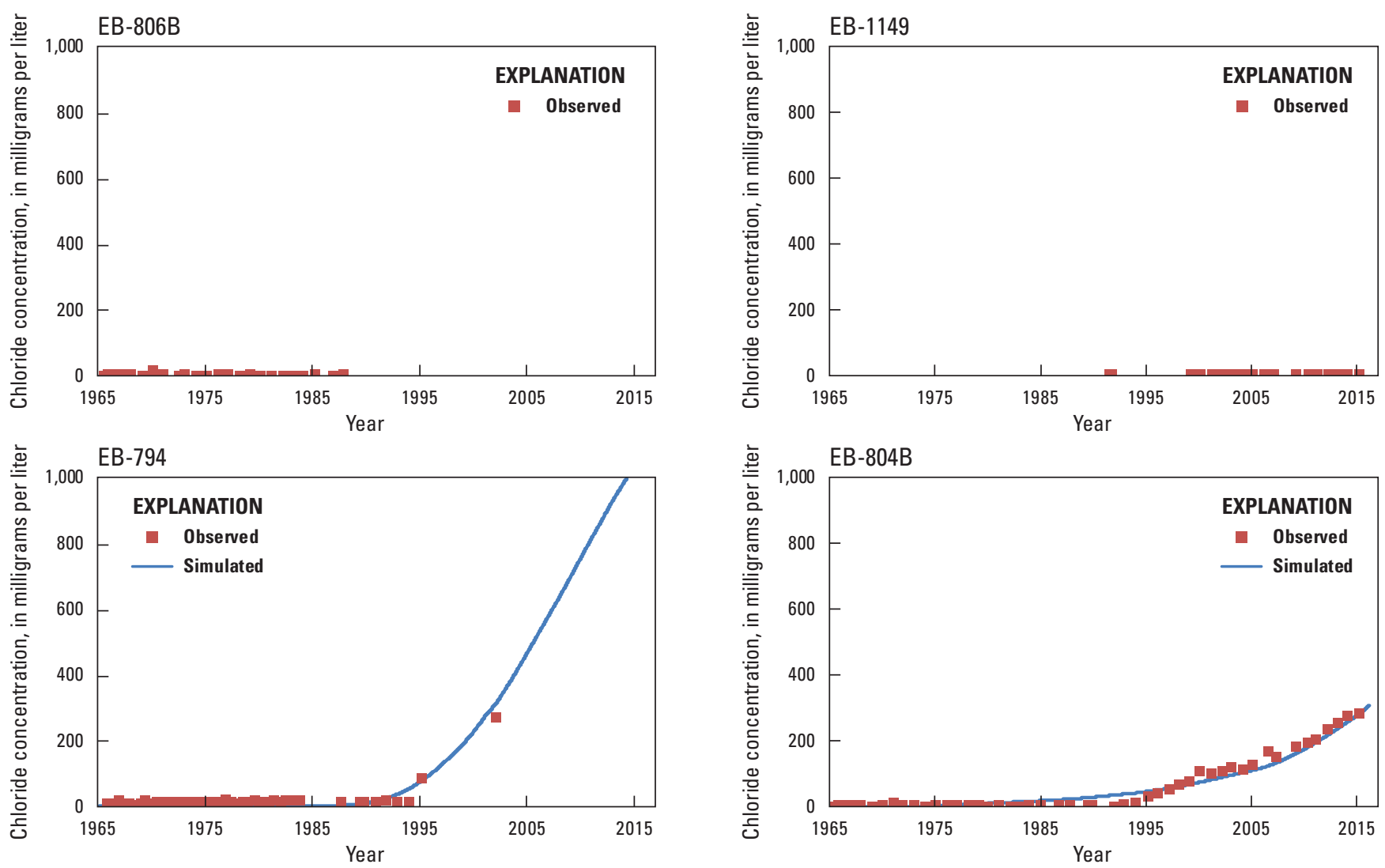

Figure 16. Simulated and observed chloride concentrations at observation wells within the "2,400-foot" sand of the Baton Rouge area in southeastern Louisiana. 

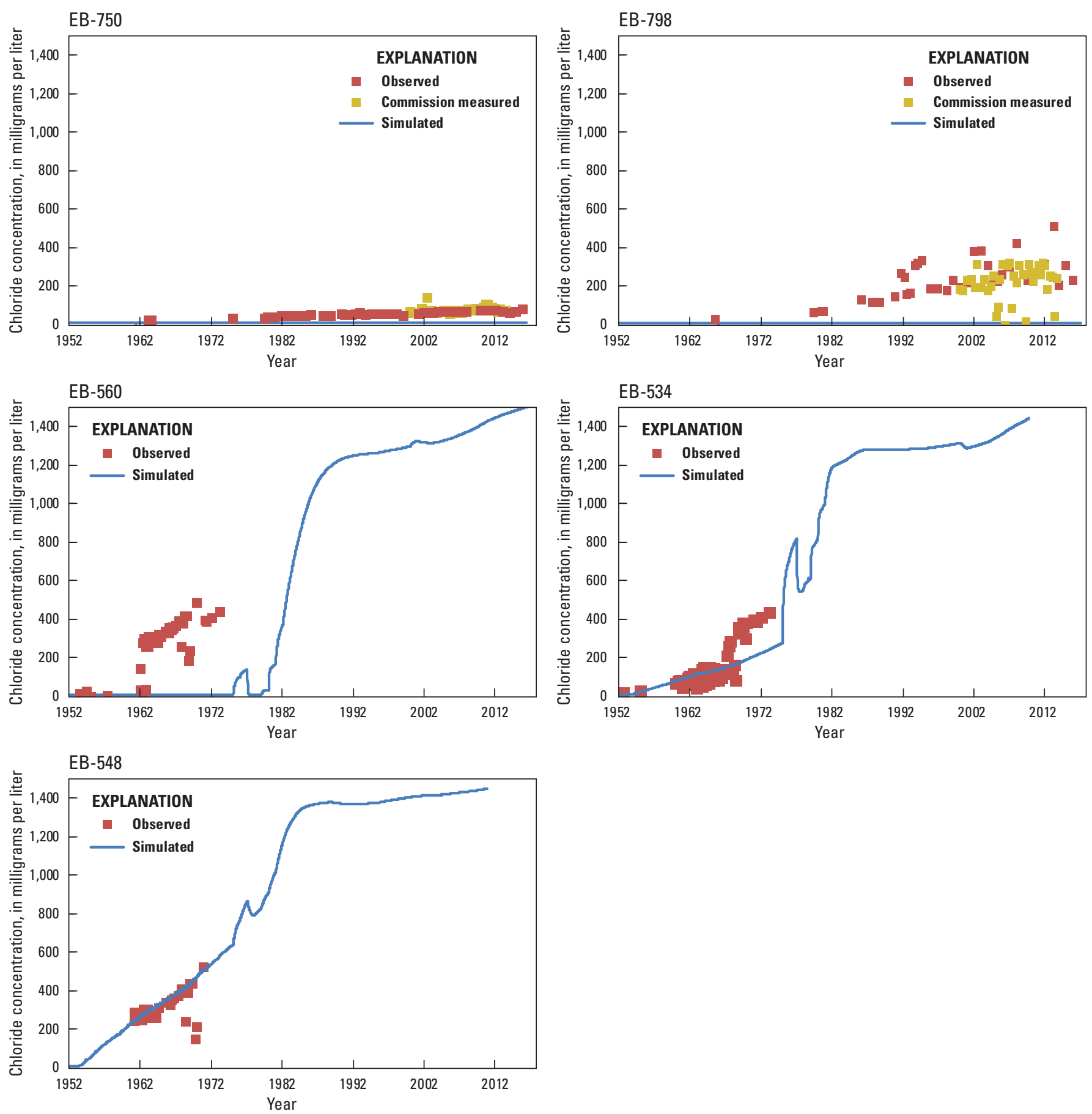

Figure 17. Simulated and observed chloride concentrations at observation wells within the "2,800-foot" sand of the Baton Rouge area in southeastern Louisiana. 


\section{Parameter Sensitivities}

The composite parameter sensitivities listed in table 2 are a measure of the relative influence of a model parameter on simulated water levels. They also reflect the total amount of information provided by the water-level observations for estimation of a model parameter (Hill and Tiedeman, 2007), and therefore correlate with the certainty of the parameter value. The composite parameter sensitivities computed with PEST++ have been scaled to facilitate comparison in table 2. In general, the values of parameters with larger composite sensitivities (greater than about 1) were relatively well estimated and have correspondingly greater certainty. Parameters with smaller composite sensitivities were more difficult to estimate and have greater uncertainty.

\section{Estimated Parameter Values}

The values of hydraulic-conductivity parameters were freely estimated within ranges considered physically reasonable for alluvial sedimentary deposits (Freeze and Cherry, 1979) without external constraint. During the parameter-estimation regression, two relatively insensitive parameters representing specific storage (ss_20con24 and ss_2800sand), which is a function of the compressibility of water, and possible values of porosity and aquifermatrix compressibility, drifted down and were constrained by a lower-limiting value of $1 \times 10^{-6} \mathrm{ft}^{-1}$. The parameter representing specific storage of the " 2,000 -foot" sand (ss_2000sand) was relatively sensitive but constrained by an upper limit $\left(1 \times 10^{-5} \mathrm{ft}^{-1}\right)$ that is based on reasonable elastic matrix compressibility (Riley, 1998) for a sand aquifer. Because the inelastic compaction that causes land subsidence is not simulated in the model, measurements of water-level changes in areas where inelastic compaction may be releasing water from storage may influence simulated $\mathrm{S}_{\mathrm{s}}$ parameters toward values unrealistically high for elastic $\mathrm{S}_{\mathrm{s}}$. The values of horizontal hydraulic conductivity $\left(\mathrm{K}_{\mathrm{h}}\right)$ at several pilot points within the "1,500-foot" sand, "2,400-foot" sand, and "2,800-foot" sand were limited to values less than 210 feet per day. Although conductivity may be higher locally in alluvialchannel sands, it is unlikely to be higher at the larger scales represented by the model grid cells.

Homogeneous effective porosities within aquifers were estimated to be 14 percent in the "1,500-foot" sand and 15 percent in the "2,400-foot" and " 2,800 -foot" sands. These effective porosities are similar to the 15 percent simulated in the model of the "1,200-foot" and "2,000-foot" sands (Heywood and others, 2015).

\section{Calibration Assessment}

Model calibration was assessed by the overall fit of simulated to observed water levels computed by the objective function with PEST++, the "reasonableness" of the estimated parameter values (table 2), the fit of simulated to observed chloride values, and any bias in the spatial and temporal distribution of water-level residuals. Residuals were calculated by subtracting simulated water-level altitudes from the observed water-level altitudes. The distribution of water-level residuals versus simulated water-level altitudes (fig. 18) is devoid of any trend deviating from the horizontal abscissa that would suggest systematic model bias.

Summary statistics were calculated for the 6,868 uniformly weighted residuals of the water-level observations used in the regression. The mean water-level residual of $-0.28 \mathrm{ft}$ is sufficiently small to confirm lack of bias in the number of positive versus negative residuals. The root-meansquare error, calculated as the square root of the mean of the squared residuals, was $19.4 \mathrm{ft}$, which is 3 percent of the $645-\mathrm{ft}$ range of measured water-level altitudes.

\section{Simulated Groundwater Levels}

Prior to the commencement of substantial withdrawals in the 1930s, groundwater within the Baton Rouge sands generally flowed from structurally higher areas near the Louisiana-Mississippi border southward and southwestward toward the Baton Rouge area (Heywood and others, 2014). After 77 years of groundwater withdrawals (1940-2016), groundwater levels declined in the Baton Rouge area and caused groundwater to flow toward the areas of withdrawals in each aquifer. Contours delineating decreasing water-level altitudes simulated for 2016 (figs. 10, 12, 14) encompass the areas where large groundwater withdrawals are specified in the "1,500-foot" sand, "2,400-foot" sand, and " 2,800 -foot" sand (figs. 6, 7, 8, respectively).

Within the "1,500-foot" sand, a simulated "cone of depression" (area of groundwater-level drawdown) is centered at a pumping center located about $0.7 \mathrm{mi}$ east of Interstate 110 , where the lowest contoured water-level altitude is about $-140 \mathrm{ft}$ (fig. 10). About $0.7 \mathrm{mi}$ farther south of the pumping center, withdrawals that commenced in 2014 from the "scavenger well" have decreased water levels in the "1,500-foot" sand. Simulated water levels are mostly within $15 \mathrm{ft}$ of measured water levels in wells that are screened in the "1,500-foot" sand in East Baton Rouge Parish and whose data are illustrated as hydrographs in figure 9 . The anomalous $20-\mathrm{ft}$ water-level rise observed in well EB-792A was not simulated.

Within the "2,400-foot" sand, the area of greatest simulated drawdown is located in the industrial district east of the Mississippi River, where the lowest simulated water-level altitude is $-260 \mathrm{ft}$ (fig. 12). Simulated water levels generally track the historical trends measured in wells in East and West Baton Rouge Parishes, though the observed 27-ft water-level rise after 2007 in well EB-794 was not simulated (fig. 11).

Within the "2,800-foot" sand, water-level altitudes below $-50 \mathrm{ft}$ are simulated for 2016 about 12 mi northwest of the industrial district near lat $30^{\circ} 39^{\prime} \mathrm{N}$., long $91^{\circ} 16.5^{\prime} \mathrm{W}$. (fig. 14). 


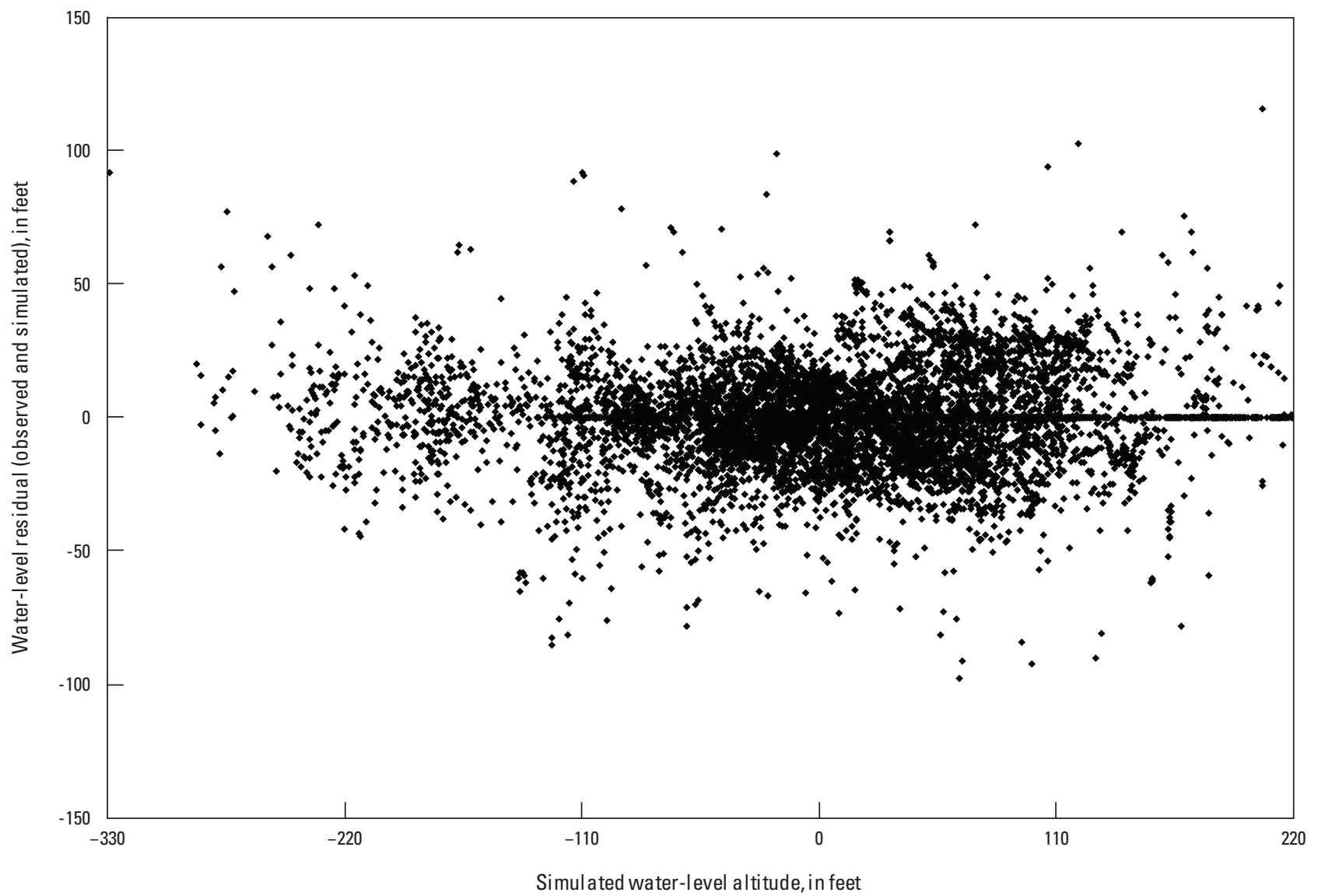

Figure 18. Water-level residuals in relation to simulated water-level altitude.

Although annual withdrawals from the "2,800-foot" sand have been greater than from the "2,400-foot" sand or " 1,500 -foot" sand since 1969 (fig. 5), relatively high simulated hydraulic conductivity near withdrawals from the "2,800-foot" sand contribute to the relatively modest water-level drawdown in those areas. Water-level contours bend across the area of increasing simulated concentrations of chloride, because the increasing groundwater density affects simulated water levels, which represent levels that would be measured in a well (if the chloride concentration within the wellbore and aquifer are equal).

\section{Simulated Groundwater Budget}

Under predevelopment conditions, the simulated steadystate water budget indicates that about $195 \mathrm{Mgal} / \mathrm{d}$ of water entered and exited the groundwater-flow model domain (table 3). A net inflow of $8.7 \mathrm{Mgal} / \mathrm{d}$ is simulated from the top specified-head model layer (which represents the upper aquifers) through the underlying confining-unit model layer. This inflow is balanced by net outflow through the constant-head boundary along the southernmost row of the deepest model layer. Under transient conditions, groundwater withdrawals (177 Mgal/d net during 2016) cause water levels to decline in the aquifers, resulting in generally larger downward hydraulic gradients and a larger net infiltration from the top specified-head model layer of $147 \mathrm{Mgal} / \mathrm{d}$ during 2016. The specified water-level changes in the top model layer result from processes not explicitly simulated in the model, including upper aquifer storage changes, evapotranspiration, and recharge. Recharge to and discharge from the upper aquifers are therefore not represented in the simulated water budget. Inflows from storage simulated in model layers 2-28 represent water from aquifer-matrix compression and water expansion.

\section{Simulated Concentrations}

Simulated chloride-concentrations are generally comparable to concentrations measured since 1964 for most of the wells screened within the "1,500-foot" sand (fig. 15). Concentrations simulated for wells EB-918 and EB-771, 
Table 3. Simulated steady-state and transient flow rates.

[SP, stress period; TS, time step; $\mathrm{ft}^{3} / \mathrm{d}$, cubic foot per day; Mgal/d, million gallons per day]

\begin{tabular}{|c|c|c|c|c|c|}
\hline \multicolumn{2}{|c|}{ Budget component } & \multicolumn{2}{|c|}{$\begin{array}{c}\text { Steady-state SP } 1 \\
\text { (pre-1940) }\end{array}$} & \multicolumn{2}{|c|}{$\begin{array}{c}\text { Transient SP 78, TS } 5 \\
\text { (Dec. 31, 2016) }\end{array}$} \\
\hline & & $\mathrm{ft}^{3 / d}$ & Mgal/d & $\mathrm{ft}^{3} / \mathrm{d}$ & Mgal/d \\
\hline \multirow{5}{*}{ In } & Specified-head layer 1 & $2.60 \times 10^{7}$ & 194.6 & $3.33 \times 10^{7}$ & 249.2 \\
\hline & South row of layer 28 & $3 \times 10^{4}$ & 0.2 & $3.35 \times 10^{6}$ & 25.1 \\
\hline & Storage & 0 & 0 & $1.07 \times 10^{6}$ & 8.0 \\
\hline & Wells & 0 & 0 & $1.37 \times 10^{5}$ & 1.0 \\
\hline & Total & $2.6 \times 10^{7}$ & 194.8 & $3.8 \times 10^{7}$ & 283.2 \\
\hline \multirow{5}{*}{ Out } & Specified-head layer 1 & $2.49 \times 10^{7}$ & 186 & $1.37 \times 10^{7}$ & 102.2 \\
\hline & South row of layer 28 & $1.1 \times 10^{6}$ & 8.8 & 0 & 0 \\
\hline & Storage & 0 & 0 & $4.33 \times 10^{5}$ & 3.2 \\
\hline & Wells & 0 & 0 & $2.376 \times 10^{7}$ & 177.8 \\
\hline & Total & $2.6 \times 10^{7}$ & 194.8 & $3.8 \times 10^{7}$ & 283.2 \\
\hline \multirow{5}{*}{ Net } & Specified-head layer 1 & $1.2 \times 10^{6}$ & 8.7 & $1.96 \times 10^{7}$ & 147 \\
\hline & South row of layer 28 & $-1.2 \times 10^{6}$ & -8.7 & $3.35 \times 10^{6}$ & 25 \\
\hline & Storage & 0 & 0 & $6.35 \times 10^{5}$ & 4.7 \\
\hline & Wells & 0 & 0 & $-2.36 \times 10^{7}$ & -176.7 \\
\hline & Total & 0 & 0 & 0 & 0 \\
\hline
\end{tabular}

which are located on the east side of the simulated plume (fig. 10), increased during the 1980s, whereas measured concentrations remained near background concentrations until after that period. The good fit of simulated to measured concentrations for well EB-807A, which is in the center of the simulated plume, indicates the eastern edge of the plume may have been slightly farther west than simulated during the 1990s. It is likely that nonsimulated aquifer heterogeneities create preferential transport pathways through the Baton Rouge sands. Attempts to improve the fit of simulated concentrations in wells EB-918, EB-771, and EB-413 with simple adjustments of initial concentrations and transport parameters while retaining adequate fits at other observation wells were unsuccessful. Because maintenance of simple initial conditions and parameter distributions was deemed preferable, the less than optimal model fit in wells EB-918, EB-771, and EB-413 was accepted. Concentrations measured after 2000 are more accurately simulated in these wells, which are near the eastern side of the simulated saltwater plume.

Simulated chloride concentrations adequately fit concentrations measured since 1965 in observation wells north of the Baton Rouge Fault screened in the "2,400foot" sand (fig. 16). Substantial groundwater withdrawals from well EB-1149 (1,726 gal/min in 2016) have generated a water-level cone of depression centered $920 \mathrm{ft}$ south of well EB-806B, toward which saltwater is migrating (fig. 12). Because chloride concentrations measured in well EB-806B have not increased above background concentrations, it is possible saltwater has been captured by withdrawals from well EB-1149.

The timing and rate of simulated chloride concentration increases differ amongst the group of three closely spaced wells screened in the "2,800-foot" sand in the industrial district: EB-548, EB-534, and EB-560 (fig. 17). Concentrations simulated for well EB-548, the southernmost of the wells screened in the "2,800-foot" sand in the industrial district, mostly conform to measured concentrations. Simulated concentration increases in wells EB-534 and EB-560 are less accurate, because simulated withdrawals from these wells contain groundwater that originates north of the industrial district and has a lower chloride concentration. Various simple concentration initial-condition configurations were tested, but none improved the fit simulated to observed chloride concentrations in EB-534 and EB-560 without degrading the fit to observed concentrations in EB-548. The sporadic but gradually increasing chloride concentrations observed in EB-798 were not fit with the simulated advection rate of the saltwater plume. This suggests the observed chloride concentration increases result from either (1) a closer saltwater source of unknown location, or (2) nonsimulated preferential flow pathways that enable faster transport from the south. 


\section{Limitations and Appropriate Use of the Model}

The groundwater model was designed and calibrated primarily to simulate groundwater flow and saltwater transport in the "1,500-foot," "2,400-foot," and "2,800-foot" sands of the Baton Rouge area. Scenarios simulating water-level or chloride concentration changes in these three aquifers resulting from possible pumping rate or location changes are appropriate applications of the model. Several example applications are described in the "Scenarios to Mitigate Saltwater Migration" section of this report. Chloride concentration changes in the other Baton Rouge Sands should not be simulated, because solute boundary and initial conditions were not defined for the other aquifers in this model.

The model was calibrated to water levels measured in aquifers beneath the " 400 -foot" sand, and water levels simulated in these aquifers could be used for various purposes, including predicting the effects of changing pumping rates. Because simulated hydraulic conductivity within each of the "600-foot," "800-foot," "1,000-foot," "1,200-foot," "1,700-foot," and "2,000-foot" sands is homogeneous, simulated water levels in some areas of these aquifers are less accurate than within the "1,500-foot," "2,400-foot," and "2,800-foot" sands, where more complex hydraulic conductivity distributions were estimated.

The model grid finite-difference cells are smallest and enable greatest numerical accuracy in the Baton Rouge area (fig. 1). Model cell sizes increase toward the perimeter of the model domain, where some cells also have large aspect ratios (long side divided by short side). Water levels simulated in larger cells or large aspect-ratio model cells will generally be less accurate.

\section{Scenarios to Mitigate Saltwater Migration}

Three groundwater-management scenarios were simulated to evaluate the effects of different groundwater withdrawals on future groundwater levels and saltwater concentrations. All scenarios simulate an additional 96 years (2017 through 2112), and the water levels and concentrations simulated for 2047 and 2112 under each scenario are compared. The first (scenario 1) represents a continuation of the current (2016), or "status quo," groundwater withdrawals. The simulated water levels and concentrations for scenario 1 are a reference to gauge the effect on water levels and concentrations resulting from the withdrawal modifications of scenarios 2 and 3, both of which were simulated to commence in 2017. Scenario 2 simulates discontinuing 10,620 gal/ min of withdrawals from selected wells in the " 2,800 -foot" sand. Scenario 3 simulates reallocating 2,000 gal $/ \mathrm{min}$ of withdrawals from the "1,500-foot" sand to the "2,800-foot" sand in the same area as the discontinued withdrawals of scenario 2. Scenario 3 simulates an aquifer-withdrawal reallocation, whereby withdrawals from the " 1,500 -foot" sand are decreased by $2,000 \mathrm{gal} / \mathrm{min}$, and withdrawals from the " 2,800 -foot" sand are increased by $2,000 \mathrm{gal} / \mathrm{min}$. This withdrawal reallocation is specified in the same area where withdrawals were discontinued in scenario 2 .

\section{Scenario 1: Continued Groundwater Withdrawals at 2016 Rates}

Predicted water levels within the "1,500-foot" sand for 2047 (fig. 19) are similar to those simulated for 2016 (fig. 10), but are about $4 \mathrm{ft}$ lower in the Baton Rouge area. By the year 2112 (fig. 20), after 96 years of pumping at a constant rate, groundwater levels within the laterally expanding cone of depression recover to altitudes closer to their 2016 levels as the groundwater flow system approaches a new equilibrium. During this 96-year period, saltwater originating near the Baton Rouge Fault continues to migrate north toward the public-supply wells located about $3 \mathrm{mi}$ north of the fault and about $0.7 \mathrm{mi}$ east of Interstate 110. Simulated chloride concentrations increase in areas south of the scavenger well, which extracts saltwater from the base of the "1,500-foot" sand, thereby abating saltwater migration toward the publicsupply well field farther north.

Within the "2,400-foot" sand, simulated groundwater levels in the Baton Rouge area decline (fig. 21) to altitudes about $2 \mathrm{ft}$ lower in 2047 than simulated for 2016 (fig. 12). After an additional 65 years of constant pumping, groundwater levels in the "2,400-foot" sand recover by the year 2112 (fig. 22) to within about a foot of their 2016 levels. During this 96-year period, the saltwater plume would continue to migrate toward well EB-1149, which is located about $0.2 \mathrm{mi}$ east of Interstate 110 and 0.2 mi south of observation well EB-806B (near lat $30^{\circ} 26.7^{\prime} \mathrm{N}$., long $91^{\circ} 10.7^{\prime}$ W.). Although simulated chloride concentrations increase to the south of EB-1149, this well effectively intercepts the saltwater, preventing further migration to the north. Because the quality of groundwater extracted through EB-1149 would degrade, it is unlikely that withdrawals from this well would continue at the simulated rate of 1,726 gal $/ \mathrm{min}$. Simulated chloride concentrations also increase farther east within an area about 1 mi north of the Baton Rouge Fault.

Contours of predicted water levels within the " 2,800 foot" sand for 2047 (fig. 23) are similar to, and about a foot lower than, those simulated for 2016 (fig. 14) throughout most of the Baton Rouge area. Similar to temporal changes in the "2,400-foot" sand, groundwater levels decline for several years before recovering as groundwater flows equilibrate to the constant pumping stress in the "2,800-foot" sand. After an additional 65 years of constant pumping, groundwater levels in the "2,800-foot" sand recover to within $1 \mathrm{ft}$ of their 2016 levels in the Baton Rouge area by the year 2112 (fig. 24). 


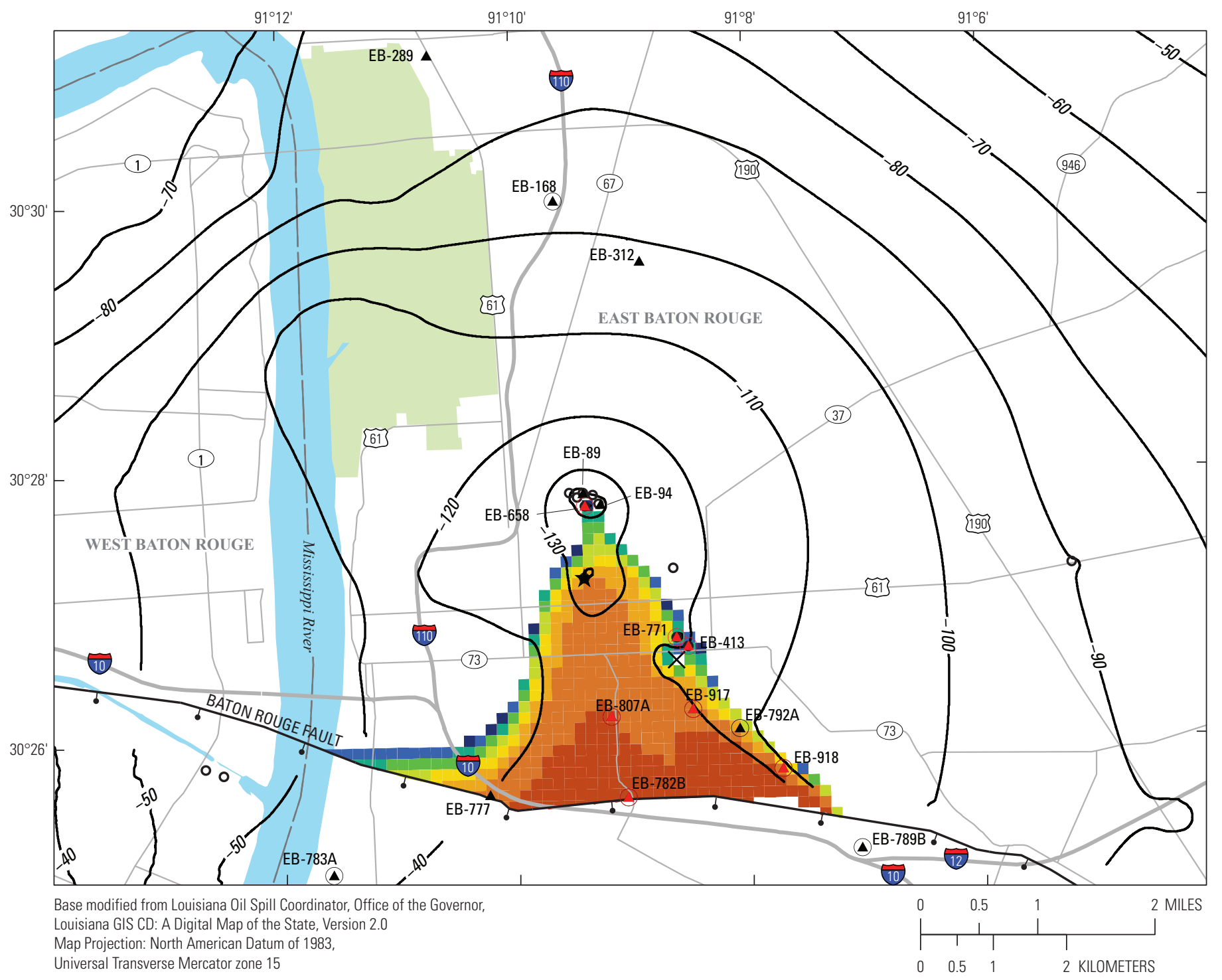

EXPLANATION

Industrial district

Predicted chloride concentration in milligrams per liter

$22-40$

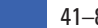

81-160

$161-320$

$321-640$

$641-1,280$

$1,281-2,560$

$2,561-5,120$

$5,121-10,000$

- -70- Simulated water-level contour-Shows altitude at which water would Contour intervalis 10 feet. Datum is Natiol Geodetic Verticat Datum of 1929

T Normal fault-Bar and ball on downthrown block

Observation well and

well number

$X \quad$ Connector well

$\star \quad$ Scavenger wel

(4) Well for which chlorograph is shown and well number

(4) Well for which hydrograph is

- Water well screened in the "1,500-foot" sand with pumping simulated in the model

Figure 19. Predicted 2047 water levels and chloride concentrations at the base of the "1,500-foot" sand of the Baton Rouge area in the detailed model area in southeastern Louisiana after continued pumping at 2016 rates (scenario 1). 


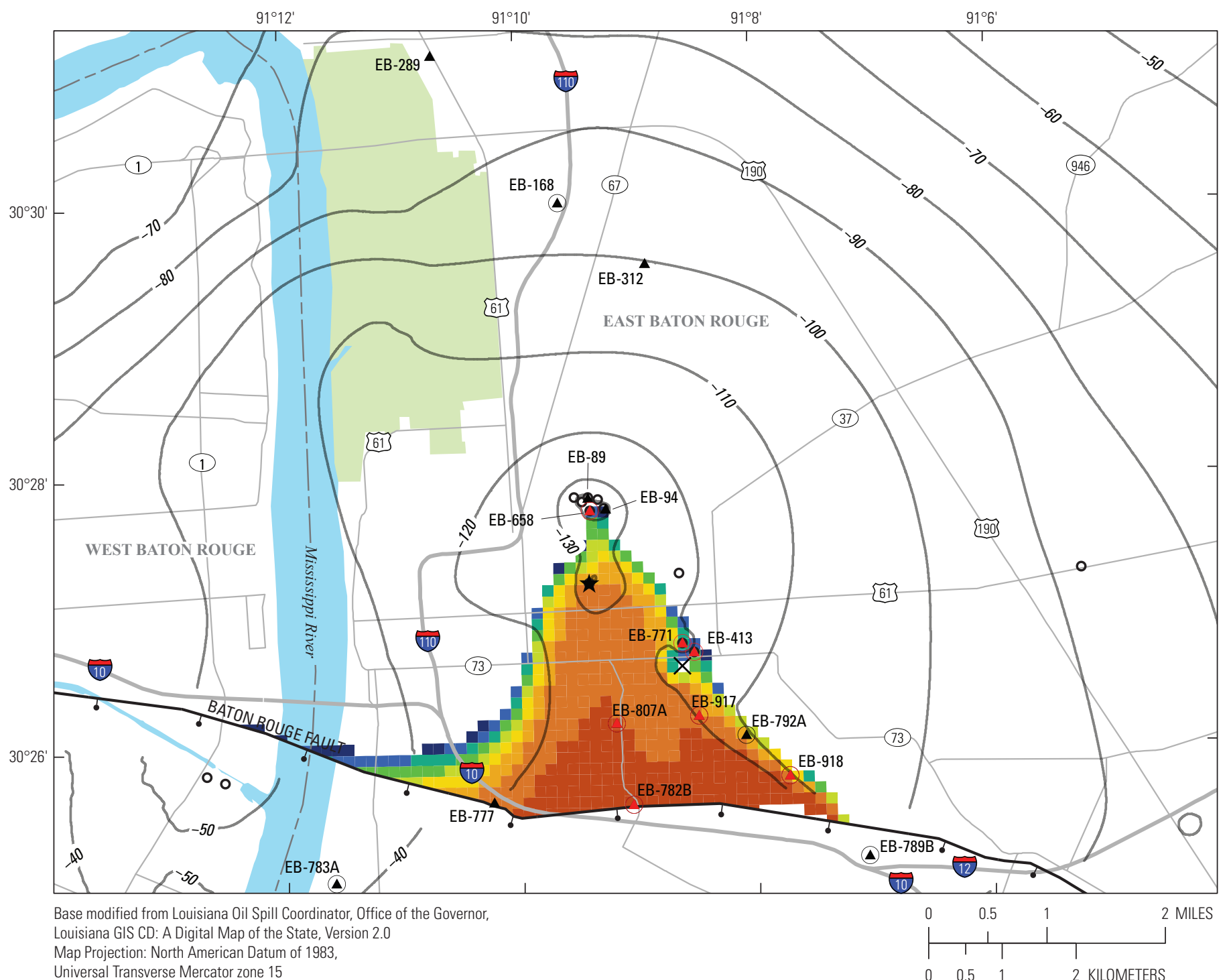

EXPLANATION

Industrial district

Predicted chloride concentration in milligrams per liter

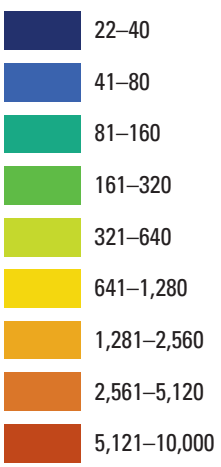

- -70- Simulated water-level contour-Shows altitude at which water would stand in tightly cased wells. Contour interval is 10 feet. Datum is National Geodetic Vertica Datum of 1929

† Normal fault-Bar and ball on downthrown block

A Observation well and well number

\section{$X \quad$ Connector well}

$\star \quad$ Scavenger well

(4) Well for which chlorograph is shown and well number Well for which hydrograph is
shown and well number

- Water well screened in the "1,500-foot" sand with pumping simulated in the model

Figure 20. Predicted 2112 water levels and chloride concentrations at the base of the "1,500-foot" sand of the Baton Rouge area in the detailed model area in southeastern Louisiana after continued pumping at 2016 rates (scenario 1). 


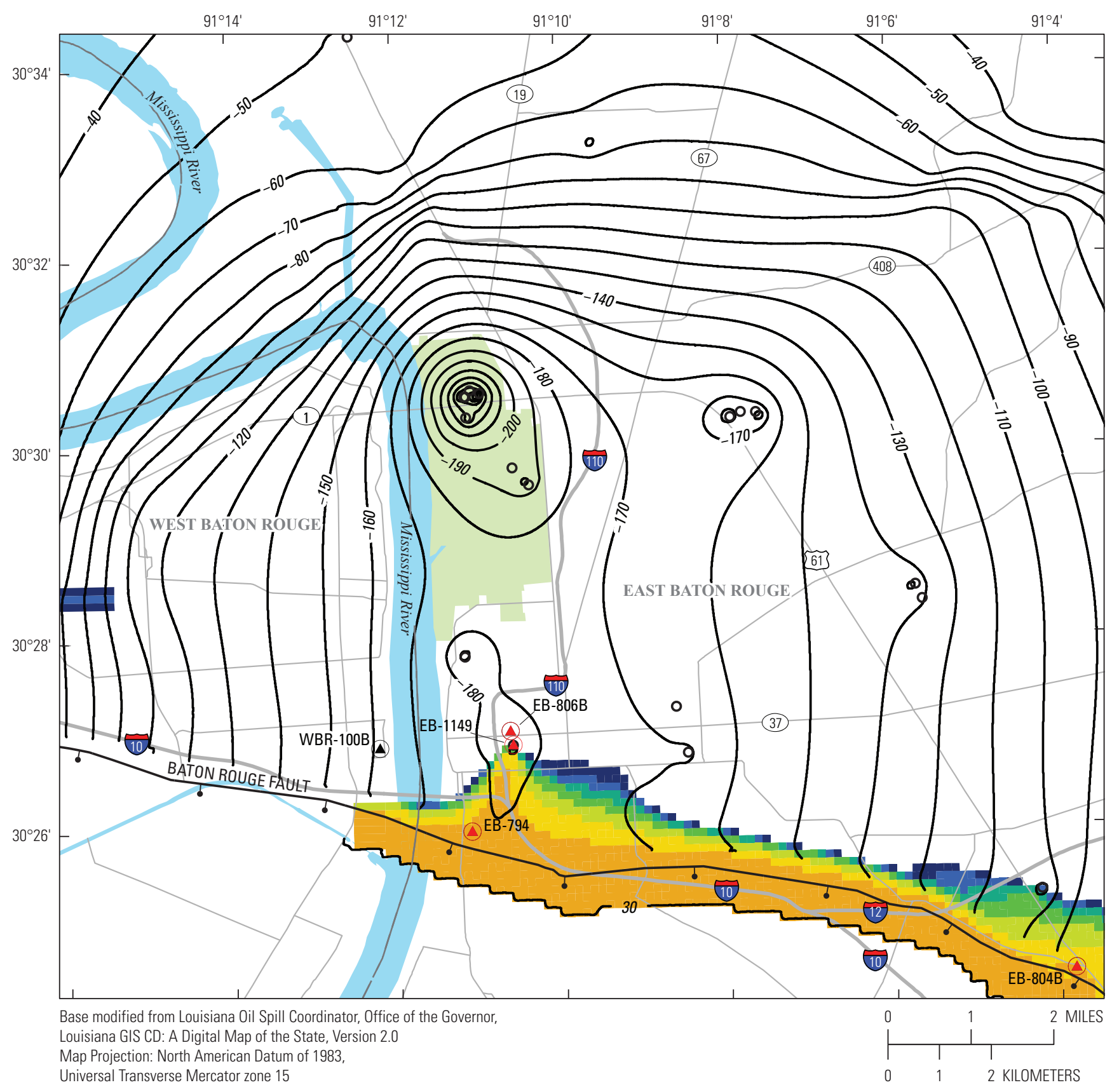

EXPLANATION

Industrial district

Predicted chloride concentration, in milligrams per liter

22-40

41-80

$81-160$

$161-320$

$321-640$

$641-1,280$

$1,281-2,560$

$2,561-5,120$

$5,121-10,000$

- $-40-$ Simulated water-level contour-Shows altitude at which water would stand in tightly cased wells. Contour interval is 10 feet. Datum is National Geodetic Vertical Datum of 1929

T Normal fault-Bar and ball on downthrown block

Observation well and well number

(4) Well for which chlorograph is EB-806B shown and well number Well for which hydrograph is
shown and well number

o

Water well screened in the "2,400-foot" sand with pumping simulated in the model

Map Projection. NorthAmerican Datum of 1983

Figure 21. Predicted 2047 water levels and chloride concentrations in the "2,400-foot" sand of the Baton Rouge area in the detailed model area in southeastern Louisiana after continued pumping at 2016 rates (scenario 1). 


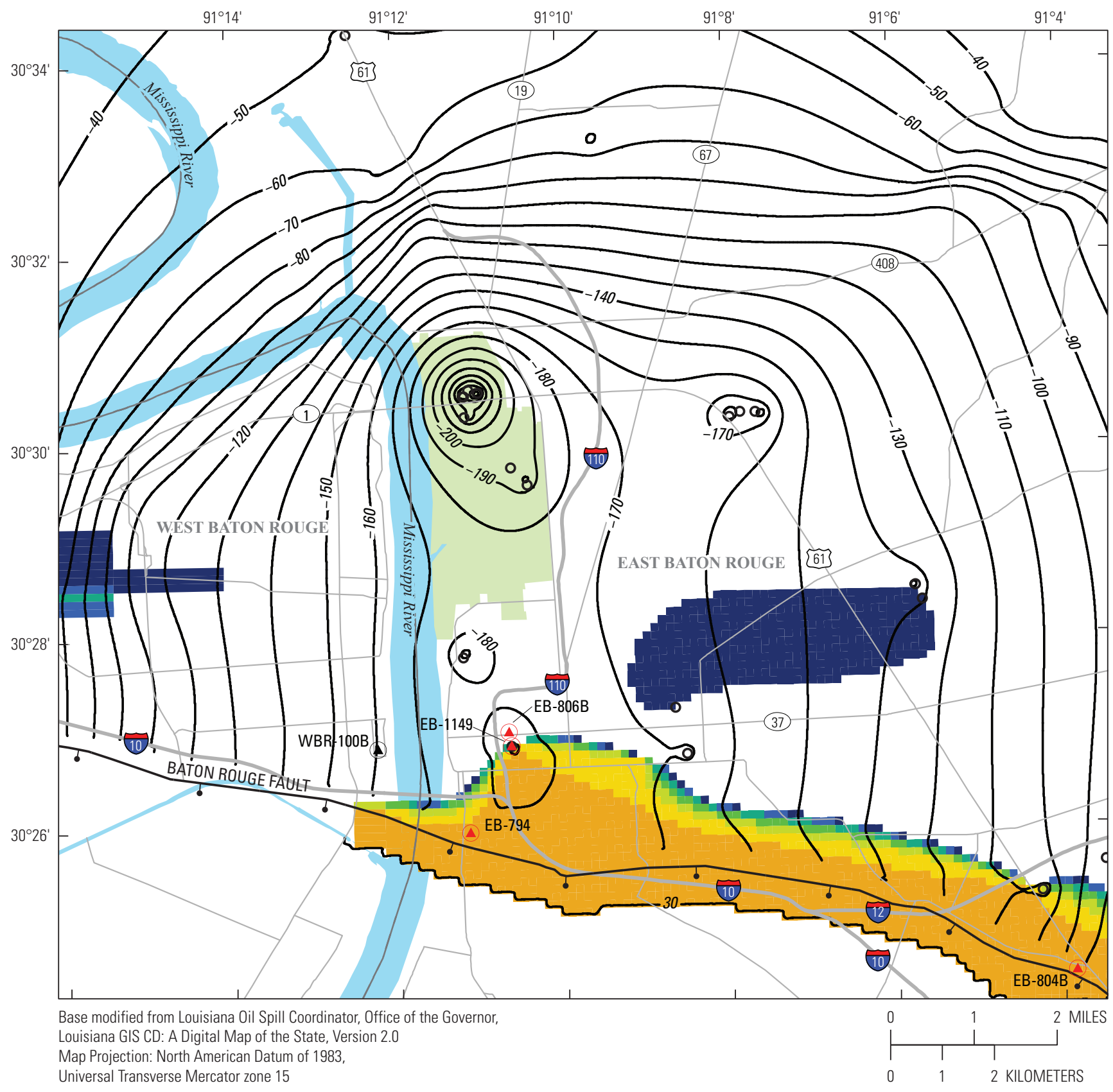

EXPLANATION

\section{Industrial district}

Predicted chloride concentration, in milligrams per liter

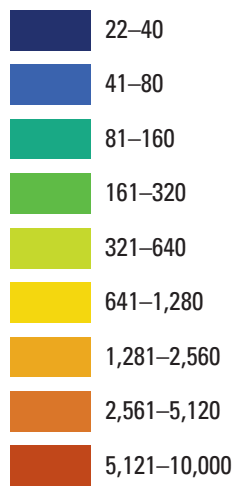

- -40 - Simulated water-level contour-Shows altitude at which water would stand in tightly cased wells. Contour interval is 10 feet. Datum is National Geodetic Vertical Datum of 1929

? Normal fault-Bar and ball on downthrown block

\section{Observation well and} well number

\section{Well for which chlorograph is
shown and well number}

(4) Well for which hydrograph is

EB-100 shown and well number

- Water well screened in the "2,400-foot" sand with pumping simulated in the model

Figure 22. Predicted 2112 water levels and chloride concentrations in the "2,400-foot" sand of the Baton Rouge area in the detailed model area in southeastern Louisiana after continued pumping at 2016 rates (scenario 1). 


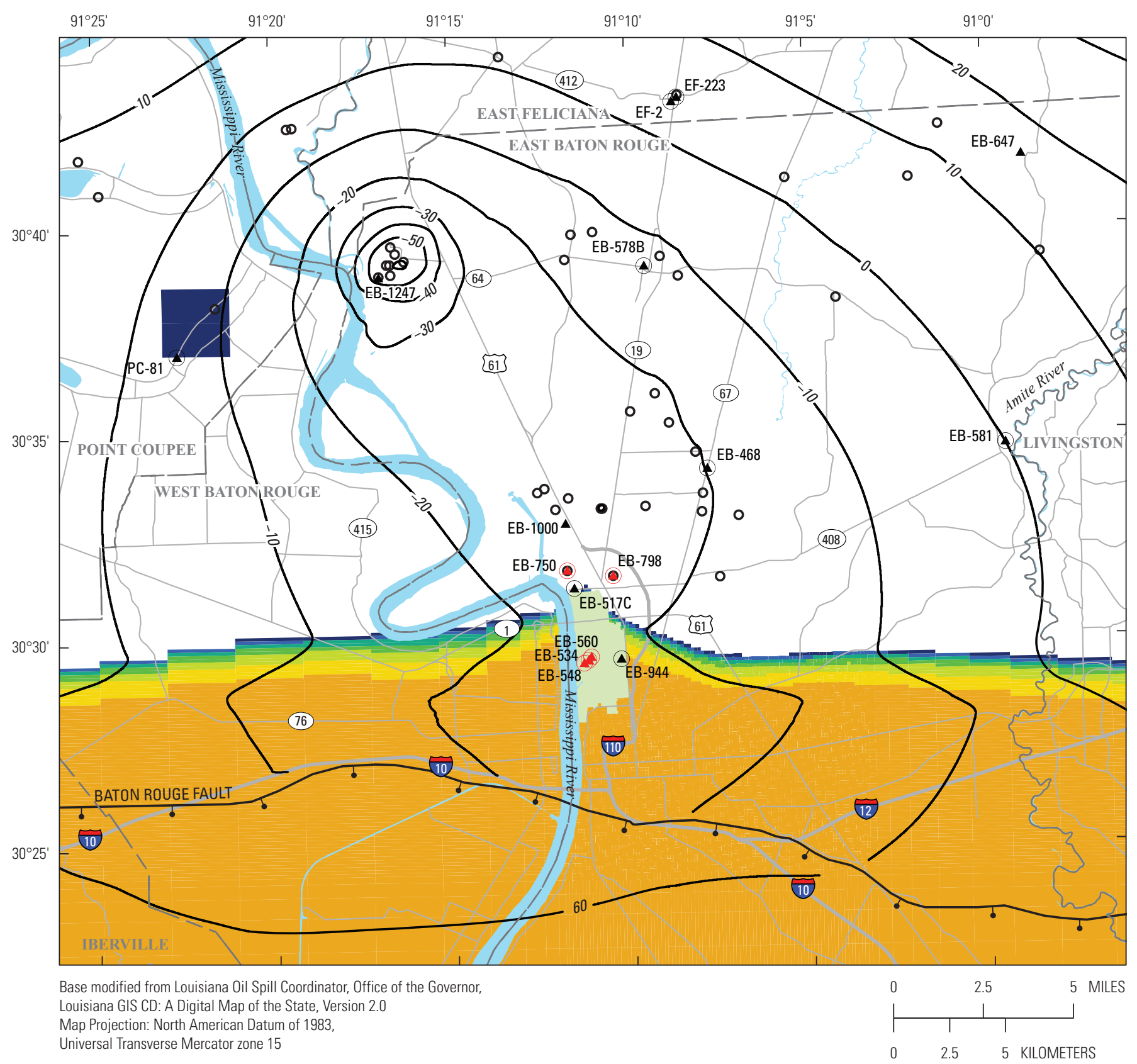

\section{EXPLANATION}

Industrial district

Predicted chloride concentration, in milligrams per liter

22-40

41-80

$81-160$

$161-320$

321-640

$641-1,280$

$1,281-2,560$

$2,561-5,120$

$5,121-10,000$

-10- Simulated water-level contour-Shows altitude at which water would stand in tightly cased wells. Contour interval is 10 feet. Datum is National Geodetic Vertical Datum of 1929

T Normal fault-Bar and ball on downthrown block

Observation well and well number Well for which chlorograph is
shown and well number

Well for which hydrograph is
shown and well number

○ wn and well number

Water well screened in the "2,800-foot" sand with pumping simulated in the model

Figure 23. Predicted 2047 water levels and chloride concentrations in the "2,800-foot" sand of the Baton Rouge area in the detailed model area in southeastern Louisiana after continued pumping at 2016 rates (scenario 1). 


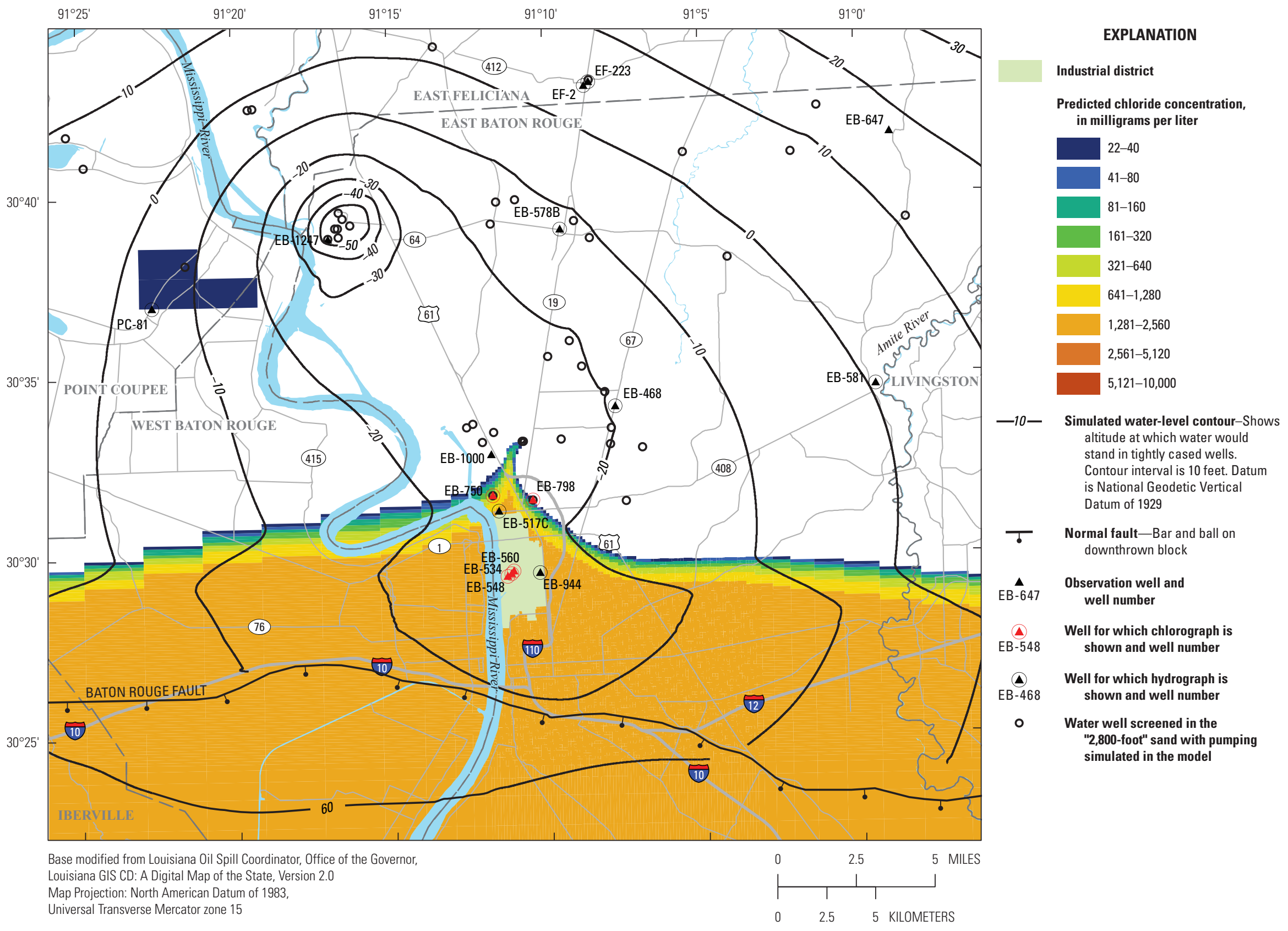

Figure 24. Predicted 2112 water levels and chloride concentrations in the "2,800-foot" sand of the Baton Rouge area in the detailed model area in southeastern Louisiana after continued pumping at 2016 rates (scenario 1). 
Saltwater would migrate northward toward withdrawal wells located about $3 \mathrm{mi}$ north of the industrial district located (near lat $30^{\circ} 33^{\prime} \mathrm{N}$., long $91^{\circ} 11.5^{\prime} \mathrm{W}$.) during the 96 -year period of "status-quo" pumping simulated in this scenario.

\section{Scenario 2: Decreased Groundwater Withdrawals From the "2,800-Foot" Sand}

Model simulations indicate groundwater levels within the "2,800-foot" sand in the area of discontinued withdrawals would recover substantially by 2047 . In the area 2 mi north of the industrial district toward which the saltwater plume would advance with "status quo" (scenario 1) withdrawals (fig. 23), groundwater levels would recover to altitudes $25-30 \mathrm{ft}$ higher than predicted for scenario 1 by 2047 (fig. 25), and recover an additional 1-2 ft by 2112 (fig. 26). The decreased hydraulic gradient simulated in this scenario retards the migration of saltwater northward, causing lower chloride concentrations to be simulated for 2047 in areas north and northwest of the industrial district than those in scenario 1. Northward saltwater migration continues to 2112 at a slower rate than in scenario 1 , though saltwater may ultimately impact withdrawal wells located in the vicinity of EB-798 (near lat $30^{\circ} 32^{\prime}$ N., long $91^{\circ} 10.5^{\prime} \mathrm{W}$.) in either scenario.

\section{Scenario 3: Redistribution of Groundwater Withdrawals From the "1,500-Foot" Sand To the "2,800-Foot" Sand}

Because existing wells located about 12 mi northwest of the industrial district near lat $30^{\circ} 39^{\prime} \mathrm{N}$., long $91^{\circ} 16.5^{\prime} \mathrm{W}$. are screened in the "1,500-foot" sand and also screened in the "1,700-foot" sand, actual implementation of this scenario would also decrease withdrawals from the " 1,700 -foot" sand unless those existing wells were modified. In comparison to the "status quo" (scenario 1) water levels predicted for 2047 within the "1,500-foot" sand (fig. 19), water levels in the "1,500-foot" sand would be about $25 \mathrm{ft}$ higher where the withdrawal reductions occur; about $2 \mathrm{ft}$ higher in the industrial district (fig. 27); but less than $1 \mathrm{ft}$ higher in the cone of depression $0.7 \mathrm{mi}$ east of Interstate 110, toward which the simulated saltwater plume is migrating. Because the predicted hydraulic gradients in this area differ only slightly between scenarios 1 and 3 , the differences in predicted chloride concentrations between these scenarios are negligible. Simulated water levels recover an additional $1-2 \mathrm{ft}$ by 2112 (fig. 28). The comparison of scenario 3 to the "status quo" (scenario 1) in 2112 is similar to that described for 2047.

Within the "2,800-foot" sand, water levels simulated for 2047 (fig. 29) are about 10-15 ft lower in the area where withdrawals are increased 2,000 gal/min (about $12 \mathrm{mi}$ northwest of the industrial district near lat $30^{\circ} 39^{\prime} \mathrm{N}$., long $91^{\circ} 16.5^{\prime} \mathrm{W}$.) in comparison to scenario 1 (fig. 23). In the area near the advancing saltwater front located about $2 \mathrm{mi}$ north of the industrial district, predicted water levels are about $5 \mathrm{ft}$ lower than the "status quo" (scenario 1) for 2047, which may result in slightly higher chloride concentrations in this area. By 2112 (fig. 30), simulated water levels recover about $1-2 \mathrm{ft}$ above the 2047 levels. The comparison of scenario 3 to "status quo" (scenario 1) water levels and chloride concentrations for 2112 are similar to those described for 2047.

\section{Summary}

Groundwater withdrawals since the 1940s have lowered water levels, altered groundwater-flow directions, and caused saltwater to intrude within some freshwater-containing sands of the fluvial-deltaic Southern Hills regional aquifer system beneath Baton Rouge, Louisiana. Groundwater investigations in the 1960s identified a freshwater-saltwater interface located at the Baton Rouge Fault, where abrupt changes in water levels also occur. Generally, aquifers south of the fault contain saltwater and aquifers north of the fault contain freshwater, although by 2005 saltwater intrusion had been detected in 7 of the 10 sand aquifers north of the fault. These aquifers, which underlie East and West Baton Rouge Parishes, Pointe Coupee Parish, and East and West Feliciana Parishes, provided about 177.3 million gallons per day for public supply and industrial use in 2016.

Future groundwater levels and saltwater concentrations in the "1,500-foot" sand, "2,400-foot" sand, and "2,800-foot" sand were simulated for three scenarios: (1) continuation of groundwater withdrawals at 2016 rates, (2) discontinuing 10,620 gallons per minute $(\mathrm{gal} / \mathrm{min})$ of withdrawals from selected wells in the "2,800-foot" sand, and (3) reallocating $2,000 \mathrm{gal} / \mathrm{min}$ of withdrawals from the " 1,500 -foot" sand to the "2,800-foot" sand.

Continuation of the 2016 (or "status quo") withdrawal rates (scenario 1) results in lower simulated water levels for 2047 around the loci of the larger groundwater withdrawals from the "1,500-foot" sand, "2,400-foot" sand, and "2,800-foot" sand. By 2112 (after an additional 65 years of constant-rate withdrawals), water levels simulated near the withdrawals recover to higher levels as water moves toward these withdrawal sites and flow in the aquifer approaches a new equilibrium. Saltwater within the "1,500-foot" sand will continue to migrate toward public-supply wells located 2.4 miles (mi) north of the Baton Rouge Fault. A "scavenger well" $0.7 \mathrm{mi}$ south of the public-supply wells removes $247 \mathrm{gal} / \mathrm{min}$ of relatively concentrated water from the base of the "1,500-foot" sand, thereby attenuating the concentration of groundwater at the public-supply wells. Saltwater within the "2,400-foot" sand would continue to encroach toward withdrawal well EB-1149, degrading water quality in that well, and farther east within an area about 1 mi north of the Baton Rouge Fault. Saltwater within the "2,800-foot" sand would migrate northward toward withdrawal wells located about $3 \mathrm{mi}$ north of the industrial district. 


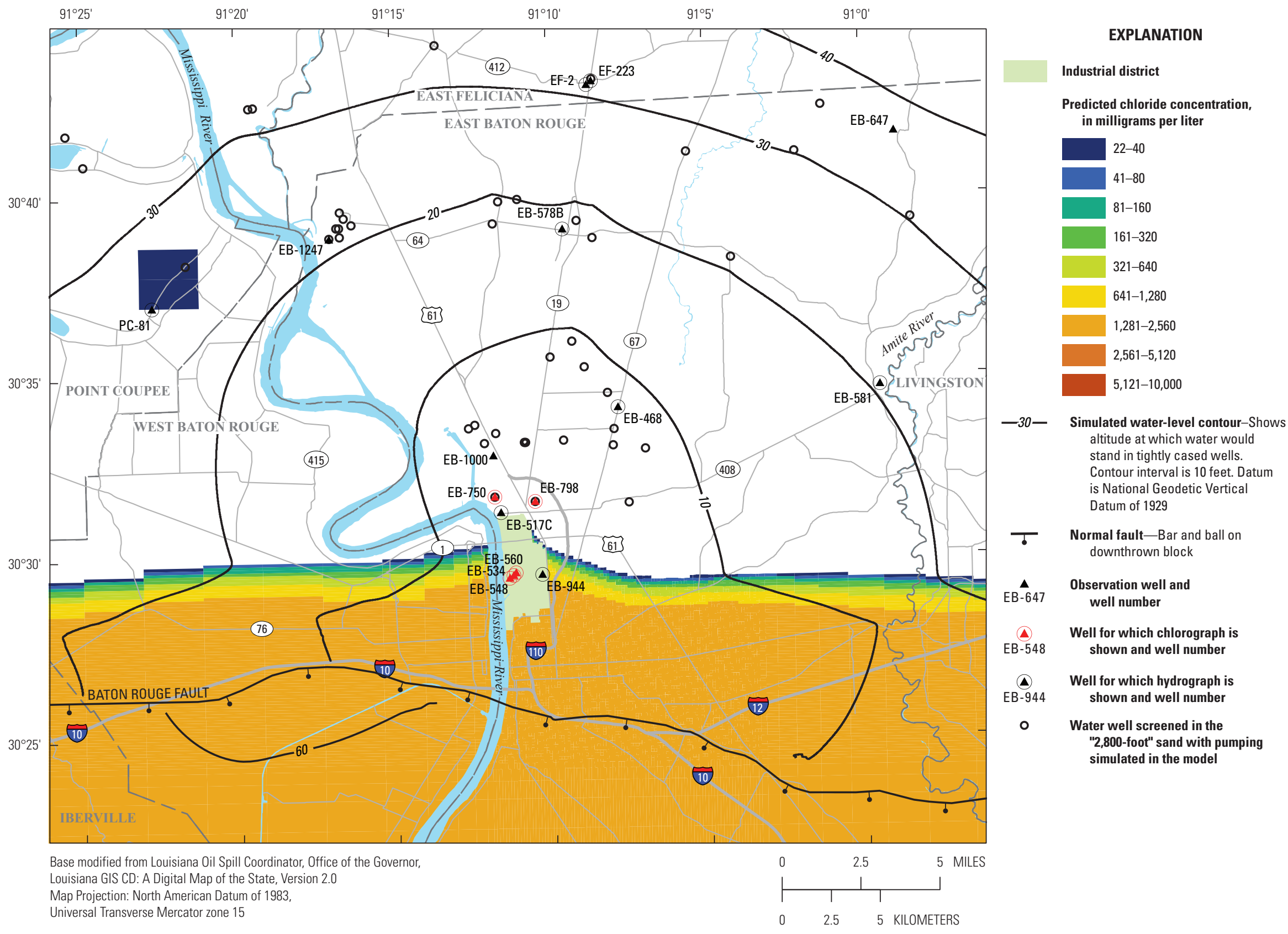

Figure 25. Predicted 2047 water levels and chloride concentrations in the "2,800-foot" sand of the Baton Rouge area in the detailed model area in southeastern Louisiana after cessation of pumping from selected wells screened in the "2,800-foot" sand beginning in 2017 (scenario 2). 


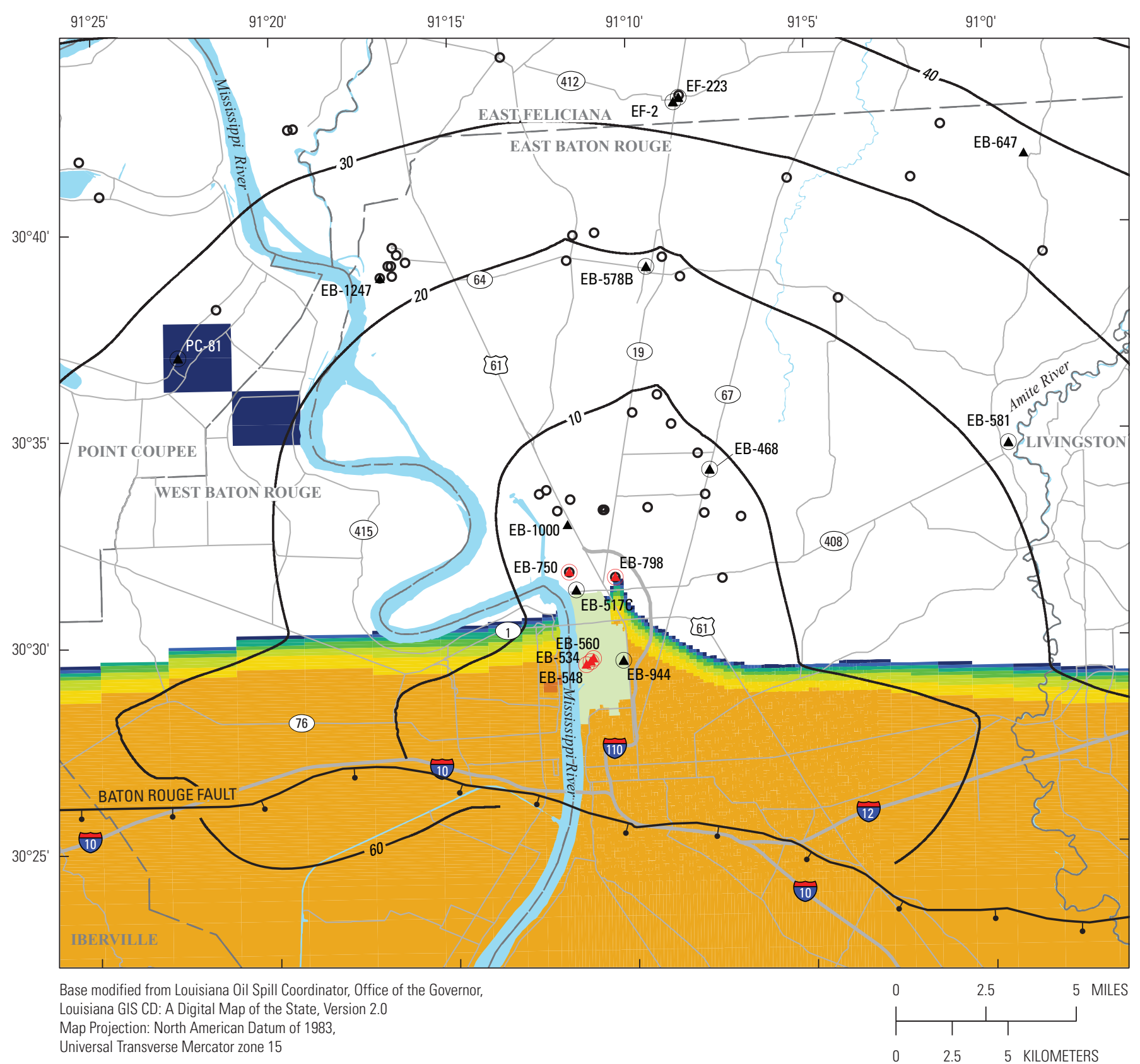

EXPLANATION

Industrial district

Predicted chloride concentration, in milligrams per liter

$22-40$

41-80

$81-160$

161-320

$321-640$

$641-1,280$

$1,281-2,560$

$2,561-5,120$

$5,121-10,000$

-30- Simulated water-level contour-Shows altitude at which water would stand in tightly cased wells. Contour interval is 10 feet. Datum is National Geodetic Vertical Datum of 1929

T Normal fault-Bar and ball on downthrown block

Observation well and well number

Well for which chlorograph is
shown and well number

(4) Well for which hydrograph is shown and well number

Water well screened in the "2,800-foot" sand with pumping simulated in the model

Figure 26. Predicted 2112 water levels and chloride concentrations in the "2,800-foot" sand of the Baton Rouge area in the detailed model area in southeastern Louisiana after cessation of pumping from selected wells screened in the "2,800-foot" sand beginning in 2017 (scenario 2). 


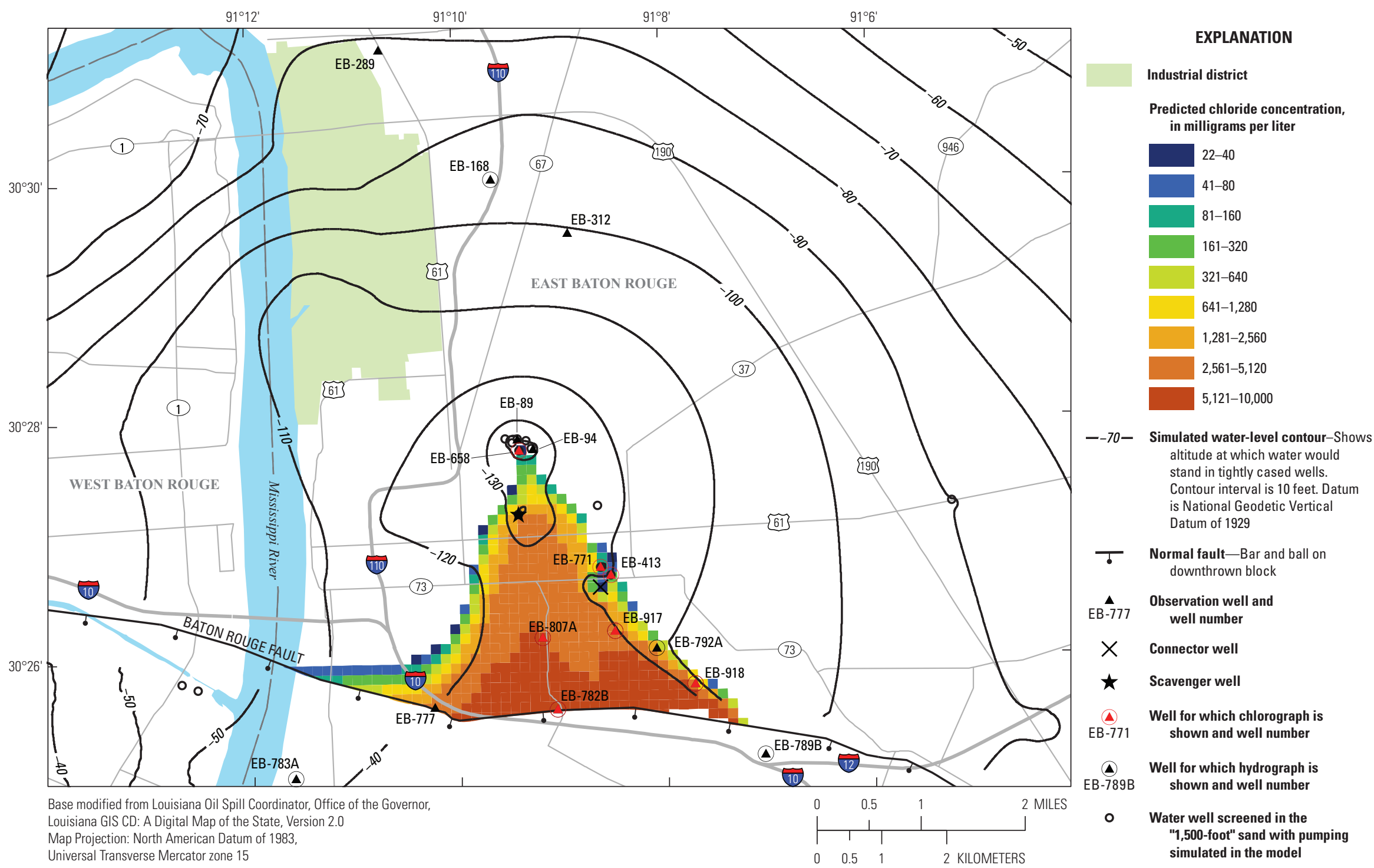

Figure 27. Predicted 2047 water levels and chloride concentrations in the "1,500-foot" sand of the Baton Rouge area in the detailed model area in southeastern Louisiana after redistribution of 2,000 gallons per minute of pumping from selected wells screened in the "1,500-foot" sand to the "2,800-foot" sand beginning in 2017 (scenario 3). 


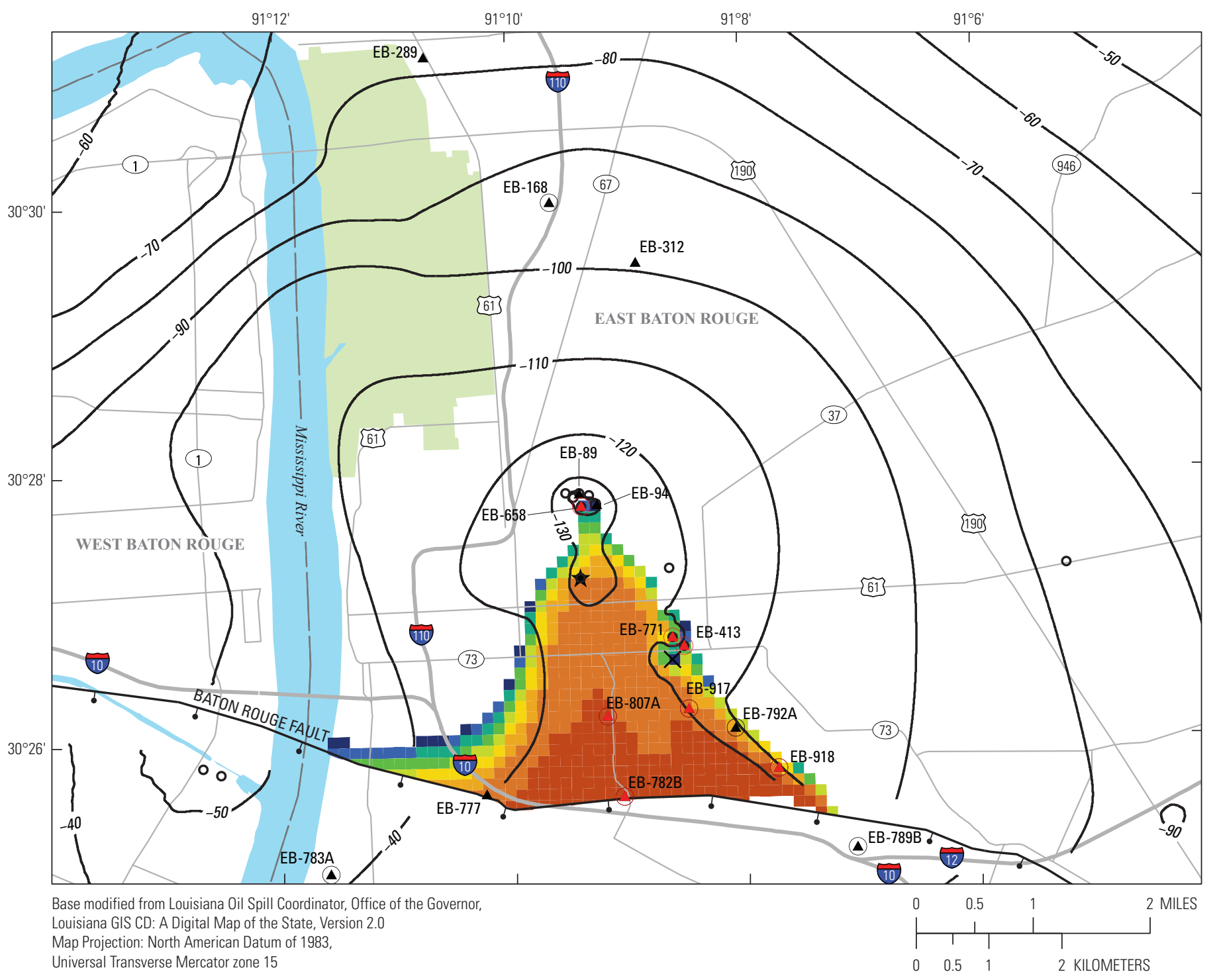

EXPLANATION

Industrial district

Predicted chloride concentration in milligrams per liter

$22-40$

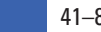

81-160

$161-320$

$321-640$

$641-1,280$

$1,281-2,560$

$2,561-5,120$

$5,121-10,000$

- -60- Simulated water-level contour-Shows altitude at which water would stand in tightly cased wells. Contour interval is 10 feet. Datum is National Geodetic Vertical Datum of 1929

- Normal fault—Bar and ball on downthrown block

$\Delta$ Observation well and well number

$X \quad$ Connector well

$\star \quad$ Scavenger well

(4) Well for which chlorograph is shown and well number

\section{(4) Well for which hydrograph is} shown and well number

- Water well screened in the "1,500-foot" sand with pumping simulated in the model

Figure 28. Predicted 2112 water levels and chloride concentrations in the "1,500-foot" sand of the Baton Rouge area in the detailed model area in southeastern Louisiana after redistribution of 2,000 gallons per minute of pumping from selected wells screened in the "1,500-foot" sand to the "2,800-foot" sand beginning in 2017 (scenario 3 ). 


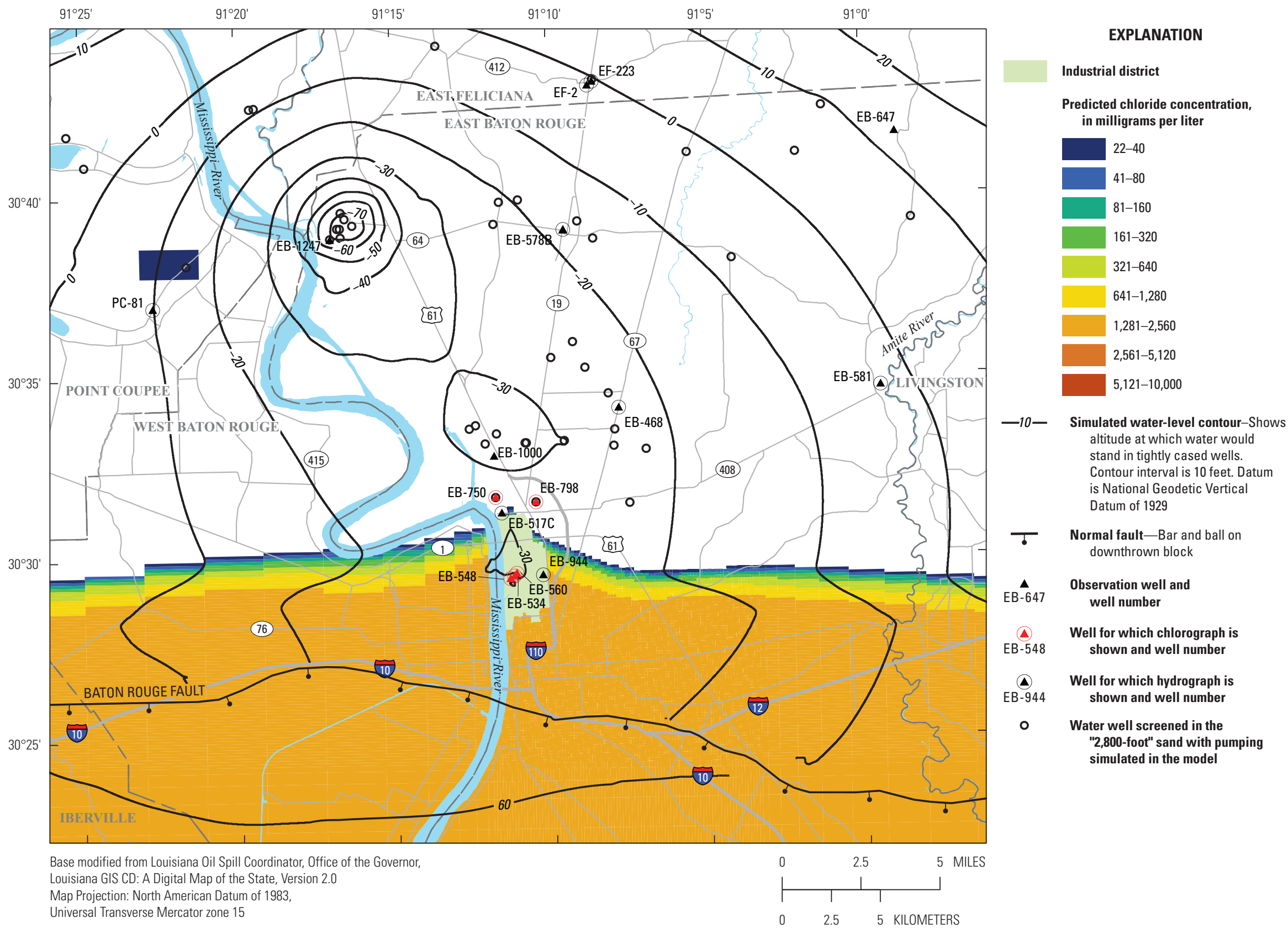

Figure 29. Predicted 2047 water levels and chloride concentrations in the "2,800-foot" sand of the Baton Rouge area in the detailed model area in southeastern Louisiana after redistribution of 2,000 gallons per minute of pumping from selected wells screened in the "1,500-foot" sand to the "2,800-foot" sand beginning in 2017 (scenario 3 ). 


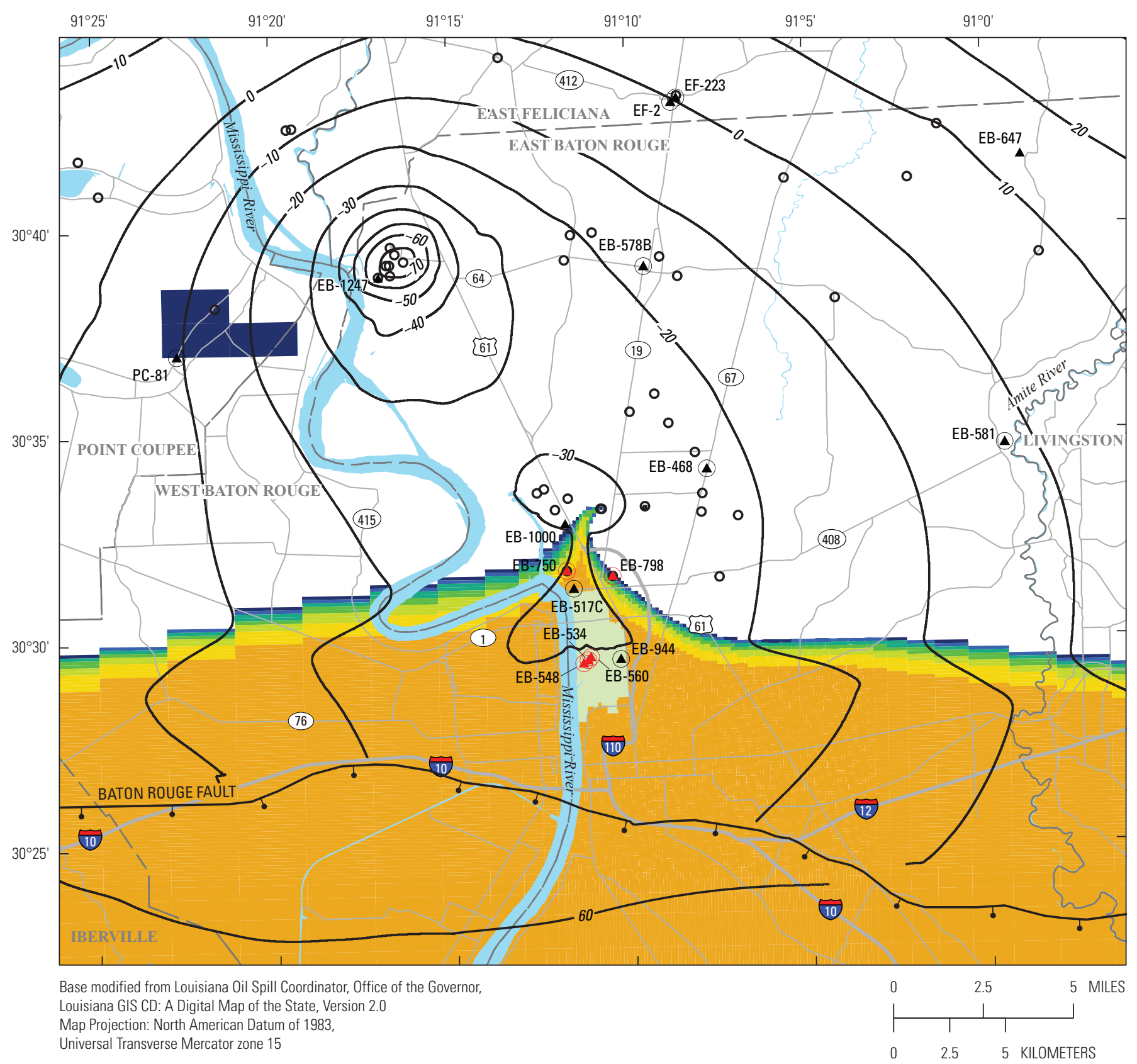

EXPLANATION

Industrial district

Predicted chloride concentration, in milligrams per liter

22-40

41-80

$81-160$

$161-320$

$321-640$

$641-1,280$

$1,281-2,560$

$2,561-5,120$

$5,121-10,000$

-10- Simulated water-level contour-Shows altitude at which water would stand in tightly cased wells. Contour interval is 10 feet. Datum is National Geodetic Vertical Datum of 1929

T Normal fault-Bar and ball on downthrown block

Observation well and well number

Well for which chlorograph is
shown and well number

Well for which hydrograph is
EB-944 shown and well number

$\circ$

Water well screened in the "2,800-foot" sand with pumping simulated in the model

Figure 30. Predicted 2112 water levels and chloride concentrations in the "2,800-foot" sand of the Baton Rouge area in the detailed model area in southeastern Louisiana after redistribution of 2,000 gallons per minute of pumping from selected wells screened in the "1,500-foot" sand to the "2,800-foot" sand beginning in 2017 (scenario 3 ). 
Cessation of $10,620 \mathrm{gal} / \mathrm{min}$ of industrial withdrawals from the "2,800-foot" sand about 12 mi northwest of the industrial district (scenario 2) would cause a substantial water-level recovery in the "2,800-foot" sand in the area of discontinued withdrawals. Groundwater levels 3 mi north of the industrial district would be 25-30 feet (ft) higher in 2047 than predicted for the "status quo" withdrawals. Saltwater encroachment toward wells north of the industrial district would be slowed because of the decreased hydraulic gradient.

In comparison to the water levels simulated for the statusquo withdrawals for 2047 , a reallocation of $2,000 \mathrm{gal} / \mathrm{min}$ of withdrawals from the " 1,500 -foot" sand to the "2,800-foot" sand (scenario 3) would cause water levels in the area of the reallocation to be about $25 \mathrm{ft}$ higher in the " 1,500 -foot" sand and about $10 \mathrm{ft}$ lower in the "2,800-foot" sand. In the area $15 \mathrm{mi}$ to the south-southeast where saltwater is encroaching in the "1,500-foot" sand, simulated 2047 water levels are less than $1 \mathrm{ft}$ higher. Because hydraulic gradients in the "1,500-foot" sand are similar to the "status quo" scenario, the difference in saltwater encroachment by 2047 and 2112 between the scenarios is therefore inconsequential. Within the "2,800-foot" sand, the area of saltwater encroachment is only $3 \mathrm{mi}$ from increased withdrawals in the "2,800-foot" sand, and water levels would be about $5 \mathrm{ft}$ lower in 2047 than for the "status quo" scenario. A larger hydraulic gradient would cause slightly faster saltwater transport, resulting in slightly higher chloride concentrations within this area of the "2,800-foot" sand.

\section{References Cited}

Bates, R.L., and Jackson, J.A., eds., 1984, Dictionary of geological terms (3d ed.): New York, Doubleday, 571 p.

Boswell, E.H., and Arthur, J.K., 1988, Generalized potentiometric surface of shallow aquifers in southern Mississippi, 1982: U.S. Geological Survey Water-Resources Investigations Report 87-4257, 1 sheet.

Buono, A., 1983, The Southern Hills regional aquifer system of southeastern Louisiana and southwestern Mississippi: U.S. Geological Survey Water-Resources Investigations Report 83-4189, 38 p. accessed Oct 24, 2019 at https:// pubs.er.usgs.gov/publication/wri834189.

Calhoun, M., and Frois, J., eds., 1997, Louisiana almanac (1997-98 ed.): Gretna, La., Pelican Publishing, 695 p.

Dial, D.C., and Cardwell, G.T., 1999, A connector well to protect water-supply wells in the "1,500-ft" sand of the Baton Rouge, Louisiana, area from saltwater encroachment: Capital Area Ground Water Conservation Commission Bulletin No. 5, 17 p.
Doherty, J., 2016, PEST—Model-independent parameter estimation, user manual part 1 (6th ed.): Watermark Numerical Computing, 366 p., accessed May 11, 2018, at http://www.pesthomepage.org/Downloads.

Durham, C.O., Jr., and Peeples, E.M. III, 1956, Pleistocene fault zone in southeastern Louisiana [abs.]: New Orleans, La., Transactions of the Gulf Coast Association of Geological Societies, v. 6, p. 65-66.

Esri, 2018, Environmental Systems Research Institute: Redlands, Calif., Esri website accessed July 19, 2019, at https://www.esri.com/en-us/arcgis/products/esridemographics/overview.

Freeze, R.A., and Cherry, J.A., 1979, Groundwater: Englewood Cliffs, N.J., Prentice-Hall, 604 p.

Griffith, J.M., 2003, Hydrogeologic framework of southeastern Louisiana: Louisiana Department of Transportation and Development Water Resources Technical Report No. 72, 21 p., 18 pls.

Griffith, J.M., 2006, Hydrogeologic maps and sections of the "400-foot," "600-foot," and "800-foot" sands of the Baton Rouge area and adjacent aquifers in East and West Baton Rouge, East and West Feliciana, and Pointe Coupee Parishes, Louisiana: U.S. Geological Survey Scientific Investigations Report 2006-5072, 15 p., 13 pls.

Halford, K.J., and Lovelace, J.K., 1994, Analysis of groundwater flow in the "1,200-foot" aquifer, Baton Rouge area, Louisiana: Louisiana Department of Transportation and Development Water Resources Technical Report No. 54, $68 \mathrm{p}$.

Hanor, J.S., 1982, Reactivation of fault movement, Tepetate fault zone, south central Louisiana: Transactions of the Gulf Coast Association of Geological Societies, v. 32, p. 237-245.

Harbaugh, A.W., 2005, MODFLOW-2005, the U.S. Geological Survey modular ground-water model-The ground-water flow process: U.S. Geological Survey Techniques and Methods, book 6, chap. A16 [variously paged].

Heywood, C.E., Griffith, J.M., and Lovelace, J.K., 2014, Simulation of groundwater flow in the "1,500-foot" sand and "2,000-foot" sand, with scenarios to mitigate saltwater migration in the "2,000-foot" sand of the Baton Rouge area, Louisiana (ver. 1.1, April 2014): U.S. Geological Survey Scientific Investigations Report 2013-5227, 63 p. [Also available at http://dx.doi.org/10.3133/sir20135227.] 
Heywood, C.E., Lovelace, J.K., and Griffith, J.M., 2015, Simulation of groundwater flow and chloride transport in the "1,200-foot" sand with scenarios to mitigate saltwater migration in the "2,000-foot" sand in the Baton Rouge area, Louisiana (ver. 1.1, September 2015): U.S. Geological Survey Scientific Investigations Report 2015-5083, 69 p. [Also available at http://dx.doi.org/10.3133/sir20155083.]

Heywood, C.E., 2019, SEAWAT model archive of chloride transport in the "1,500-foot", "2,400-foot", and "2,800-foot" sands of the Baton Rouge Area, Louisiana: U.S. Geological Survey data release, https://doi.org/10.5066/P9URJ38Q.

Hill, M.C., and Tiedeman, C.R., 2007, Effective groundwater model calibration - With analysis of data, sensitivities, predictions, and uncertainty: Hoboken, N.J., Wiley, 455 p.

Howson, L.R.,1919, Unusual ground water supply conditions at Baton Rouge, Louisiana: Journal of the American Water Works Association, v. 6, no. 2, p. 271-275. [Also available at http://www.jstor.org/stable/41224530.]

Hsieh, P.A., and Freckleton, J.R., 1993, Documentation of a computer program to simulate horizontal-flow barriers using the U.S. Geological Survey's modular three-dimensional finite-difference ground-water flow model: U.S. Geological Survey Open-File Report 92-477, 32 p. accessed Oct 24, 2019, at https://pubs.er.usgs.gov/publication/ofr92477

Huntzinger, T.L.; Whiteman, C.D., Jr.; and Knochenmus, D.D., 1985, Simulation of ground-water movement in the "1,500- and 1,700-foot" aquifer of the Baton Rouge area, Louisiana: Louisiana Department of Transportation and Development, Office of Public Works Water Resources Technical Report No. 34, 52 p.

Konikow, L.F., Hornberger, G.Z., Halford, K.J., and Hanson, R.T., 2009, Revised Multi-Node Well (MNW2) package for MODFLOW ground-water flow model: U.S. Geological Survey Techniques and Methods, book 6, chap. A30, 67 p.

Kuniansky, E.L., 1989, Geohydrology and simulation of ground-water flow in the "400-foot," "600foot," and adjacent aquifers, Baton Rouge area, Louisiana: Louisiana Department of Transportation and Development Water Resources Technical Report No. 49, 90 p.

Kuniansky, E.L., Dial, D.C., and Trudeau, D.A., 1989, Maps of the "400-foot," "600-foot," and adjacent aquifers and confining beds, Baton Rouge area, Louisiana: Louisiana Department of Transportation and Development Office of Public Works Technical Report No. 48, 28 pls.

Langevin, C.D., Thorne, D.T., Jr., Dausman, A.M., Sukop, M.C., and Guo, W., 2007, SEAWAT Version 4-A computer program for simulation of multi-species solute and heat transport: U.S. Geological Survey Techniques and Methods, book 6, chap. A22, 39 p.
Leake, S.A., and Lilly, M.R., 1997, Documentation of a computer program (FHB1) for assignment of transient specified-flow and specified-head boundaries in applications of the Modular Finite-Difference Ground-Water Flow Model (MODFLOW): U.S. Geological Survey Open-File Report 97-571, 56 p.

Lovelace, J.K., 2007, Chloride concentrations in ground water in East and West Baton Rouge Parishes, Louisiana, 200405: U.S. Geological Survey Scientific Investigations Report 2007-5069, $27 \mathrm{p}$.

Lovelace, J.K., and Lovelace, W.M., 1995, Hydrogeologic unit nomenclature and computer codes for aquifers and confining units in Louisiana: State of Louisiana, Office of Public Works, Water Resources Special Report 9, 12 p.

Martin, A., Jr., and Whiteman, C.D., Jr., 1985, Map showing generalized potentiometric surface of aquifers of Pleistocene Age, southern Louisiana, 1980: U.S. Geological Survey Water-Resources Investigations Report 84-4331, 1 sheet.

Martin, A., Jr., and Whiteman, C.D., Jr., 1990, Calibration and sensitivity analysis of a ground-water flow model of the coastal lowlands aquifer system in parts of Louisiana, Mississippi, Alabama, and Florida: U.S. Geological Survey Water-Resources Investigations Report 89-4189, 54 p.

McCulloh, R.P., 1991, Surface faults in East Baton Rouge Parish: Baton Rouge, La.: Louisiana Geological Survey Open-File Series 91-02, 25 p.

Meyer, R.R., and Rollo, J.R., 1965, Saltwater encroachment, Baton Rouge area, Louisiana: Department of Conservation, Louisiana Geological Survey, and Louisiana Department of Public Works Water Resources Pamphlet 17, 9 p.

Meyer, R.R., and Turcan, A.N., Jr., 1955, Geology and ground-water resources of the Baton Rouge area, Louisiana: U.S. Geological Survey Water-Supply Paper 1296, 138 p.

Morgan, C.O., 1961, Ground-water conditions in the Baton Rouge area, 1954-59, with special reference to increased pumpage: Department of Conservation, Louisiana Geological Survey, and Louisiana Department of Public Works Water Resources Bulletin 2, 78 p.

Morgan, C.O., and Winner, M.D., Jr., 1964, Saltwater encroachment in aquifers of the Baton Rouge areaPreliminary report and proposal: Louisiana Department of Public Works, $37 \mathrm{p}$.

Murray, G.E., 1961, Geology of the Atlantic and Gulf Coastal Province of North America: New York, Harper Brothers, $692 \mathrm{p}$.

National Oceanic and Atmospheric Administration, 1995, Climatological data annual summary - Louisiana: Asheville, N.C., Environmental Data Service, 23 p. 
Riley, F.S., 1998, Mechanics of aquifer systems, in Borchers, J.W., ed., Land Subsidence Case Studies and Current Research-Proceedings of the Dr. Joseph F. Poland Symposium: Belmont, Calif., Star Publishing, p. 13-27.

Roland, H.L., Hill, T.F., Autin, P., Durham, C.O., and Smith, C.G., 1981, The Baton Rouge and Denham SpringsScotlandville faults (mapping and damage assessment): Baton Rouge, La., Report prepared for the Louisiana Department of Natural Resources, Geological Survey and Durham Geological Associates Consultants, contract no. 21576-80-01, $26 \mathrm{p}$.

Rollo, J.R., 1969, Saltwater encroachment in aquifers of the Baton Rouge area, Louisiana: Department of Conservation, Louisiana Geological Survey, and Louisiana Department of Public Works Water Resources Bulletin 13, 45 p.

Sargent, B.P., 2011, Water use in Louisiana, 2010: Louisiana Department of Transportation and Development Water Resources Special Report No. 17, 135 p.

Smith, C.G., 1979, A geohydrologic survey of the "1,200-foot" aquifer in the Capital Area Ground Water Conservation District: Capital Area Ground Water Conservation Commission Bulletin 3, 19 p.

Smith, C.G., and Kazmann, R.G., 1978, Subsidence in the Capital Area Ground Water Conservation District-An update: Baton Rouge, La., Capital Area Ground Water Conservation Commission Bulletin 2, 31 p.

Smoot, C.W., 1988, Louisiana hydrologic atlas map no. 3-Altitude of the base of freshwater in Louisiana: U.S. Geological Survey Water-Resources Investigations Report 86-4314, 1 sheet.

Stuart, C.G., Knochenmus, D., and McGee, B.D., 1994, Guide to Louisiana's ground-water resources: U.S. Geological Survey Water-Resources Investigations Report 94-4085, $55 \mathrm{p}$.

Tomaszewski, D.J., 1996, Distribution and movement of saltwater in aquifers in the Baton Rouge area, Louisiana, 1990-92: Louisiana Department of Transportation and Development Water Resources Technical Report No. 59, $44 \mathrm{p}$.

Torak, L.J., and Whiteman, C.D., Jr., 1982, Applications of digital modeling for evaluating the ground-water resources of the "2,000-foot" sand of the Baton Rouge area, Louisiana: Louisiana Department of Transportation and Development, Office of Public Works Water Resources Technical Report No. 27, 87 p.

U.S. Census Bureau, 2010, Annual estimates of the population for counties of Louisiana-April 1, 2000, to July 1, 2004 (CO-EST2004-01-22): Accessed April 29, 2015, at http:// www.census.gov/popest.
U.S. Environmental Protection Agency, 2017, Secondary Drinking Water Standards: Guidance for Nuisance Chemicals, Accessed November 20, 2018, at https://www. epa.gov/dwstandardsregulations/secondary-drinking-waterstandards-guidance-nuisance-chemicals.

U.S. Geological Survey, 2017, USGS water data for the Nation: U.S. Geological Survey National Water Information System database, accessed July 9, 2019, at http://dx.doi. org/10.5066/F7P55KJN.

Welter, D.E., Doherty, J.E., Hunt, R.J., Muffels, C.T., Tonkin, M.J., and Schreüder, W.A., 2012, Approaches in highly parameterized inversion-PEST++, a Parameter ESTimation code optimized for large environmental models: U.S. Geological Survey Techniques and Methods, book 7, chap. C5, $47 \mathrm{p}$.

Whiteman, C.D., Jr., 1979, Saltwater encroachment in the "600-foot" and "1,500-foot" sands of the Baton Rouge area, Louisiana, 1966-78, including a discussion of saltwater in other sands: Louisiana Department of Transportation and Development, Office of Public Works Water Resources Technical Report No. 19, 49 p. 
For more information about this report, contact

Director, Lower Mississippi-Gulf Water Science Center

U.S. Geological Survey

640 Grassmere Park, Suite 100

Nashville, Tennessee, 37211

https://www.usgs.gov/centers/lmg-water

Publishing support provided by

Lafayette Publishing Service Center 


\section{$\frac{\mathbb{2}}{3}$}

정 